\title{
WATER RESOURCES ACTIVITIES OF THE NORTH CAROLINA DISTRICT OF THE U.S. GEOLOGICAL SURVEY, 1988-90
}

Compiled and edited by Rebecca J. Deckard

U.S. GEOLOGICAL SURVEY

Open-File Report 91-475

Prepared in cooperation with the

NORTH CAROLINA DEPARTMENT OF ENVIRONMENT, HEALTH, AND NATURAL RESOURCES AND

OTHER FEDERAL, STATE, AND LOCAL AGENCIES

\author{
Raleigh, North Carolina
}




\section{U.S. DEPARTMENT OF THE INTERIOR}

MANUEL LUJAN, JR., Secretary

U.S. GEOLOGICAL SURVEY

Dallas L. Peck, Director

For additional information, write to:

\section{District Chief}

U.S. Geological Survey 3916 Sunset Ridge Road

Raleigh, North Carolina 27607
Copies of this report can be purchased from:

U.S. Geological Survey Open-File Reports - ESIC Post Office Box 25425 Denver, Colorado 80225 


\section{CONTENTS}

Preface 1

Introduction 3

Sources of funds 7

Cooperating agencies 9

District organization 10

Water-resources data 12

Streamflow network in North Carolina (NCOO1) 14

Ground-water program in North Carolina (NCOO2) 16

Water-quality network in North Carolina (NCOO3) 18

Water-resources conditions 20

Water-resources investigations $\mathbf{2 8}$

$\mathrm{NCO0101-Baseline} \mathrm{water-and} \mathrm{sediment-quality} \mathrm{monitoring} \mathrm{program,}$

High Point Lake watershed, North Carolina 29

$\mathrm{NC00301-Effects} \mathrm{of} \mathrm{various} \mathrm{land-use} \mathrm{developments} \mathrm{on} \mathrm{surface-water}$ quality in the upper Neuse River basin $\mathbf{3 0}$

NCO04-Index sediment station - Yadkin River 31

NCO05-Effects of atmospheric deposition on water quality of

North Carolina streams 32

NC006-Flood insurance study for Mecklenburg County unincorporated areas 33

NC007-Water-use data-collection program in North Carolina

NC010-Effects of channel relocation and proposed bridge construction on floodflows of the Catawba River near Marion, North Carolina 36

NC053-Effects of channelization on the hydrology of Chicod Creek watershed, North Carolina 37

NC071-Coastal Plain aquifer study-Regional Aquifer Systems Analysis (RASA) 39

NC073-Water quality of inflow to and outflow from Falls and Jordan Lakes, North Carolina 41

NC074-Effects of stream restoration on hydrology of the Grove Creek watershed and Open Marsh Water Management of salt marshes at Hobucken and West Onslow Beach, North Carolina 42

NC075-Central Coastal Plain aquifer study 44 NC081-Effects of land-management practices on sediment and chemical transport in Guilford County, North Carolina 
NC082-Evaluation of the hydrogeology in the Cincinnati arch

region with regard to isolation of nuclear

wastes in buried crystalline rocks $\mathbf{4 8}$

NC083-Ground-water supply and potential for contamination, Cherry

Point Marine Corps Air Station, North Carolina 49

NC084-An appraisal of the ground-water resources of Camp Lejeune

Marine Corps Base, North Carolina 51

NC085-A reconnaissance evaluation of surface-water, drinking-

water, and effluent-water quality in the

Greensboro, North Carolina, area 53

NC086-Low-flow characteristics of North Carolina streams 54

NC087-Water-quality characteristics of selected streams

in forested areas of North Carolina 55

NC090-National ground-water atlas (Segment 10) 56

NC091-Estuarine water quality and the management of

artificial drainage from wetlands 57

NC092-Determination of flows and flow patterns in the

Pamlico River and Neuse River estuaries $\mathbf{5 9}$

NC093-Hydrologic characteristics and water-quality trends of

the Albemarle-Pamlico estuarine system. North Carolina

NC094-Development of ecological surveys for the National

Water-Quality Assessment (NAWQA) program 62

NC097-Urban stormwater hydrology in North Carolina 64

NC098-Analysis of estuarine water quality using

continuous-monitoring data 66

NC09801-Flow and salinity characteristics of West Neck

Creek, Virginia Beach, Virginia 67

NC 100-Leachate discharge at solid-waste disposal sites

in Mecklenburg County. North Carolina 68

NC 101-Surface-water quality assessment for Region J,

North Carolina 70

NC102-Statewide reservoir sedimentation program 71

NC 103-Hydrology of the Sand Hills aquifer

73

Selected publications on water resources $\mathbf{7 5}$

Surface water 77

Data reports 77

Interpretive reports $\mathbf{7 8}$

Water quality $\mathbf{8 2}$

Data reports 82

Interpretive reports 
Ground water 88

Data reports 88

Interpretive reports 89

Water use 97

\section{ILLUSTRATIONS}

Figure 1. Proportion of funding for major programs conducted by the

North Carolina District in fiscal year $1989 \quad 8$

2. Organizational chart for the North Carolina District 11

3-5. Maps showing:

3. Streamflow monitoring network stations, fiscal year $1989 \quad 15$

4. Locations of wells in the 1989 ground-water program 17

5. Water-quality monitoring network stations, fiscal year $1989 \quad 19$

6. Selected index stations in the streamflow, ground-water, and water-quality monitoring programs 21

7. Monthly rainfall for 1989 water year and average monthly rainfall for period 1951-80 22

8. Variation of water levels at selected long-term observation wells for the 1989 water year in the Blue Ridge.

Piedmont, and Coastal Plain Provinces of North Carolina 24

9. Declining ground-water levels in observation well NC-44 at

Cove City, Craven County, in the Coastal Plain Province, 1965-89 25

10. Specific conductance at Yadkin River at Yadkin College during the 1989 water year and mean specific conductance for the period 1975-89 27

11. Total suspended-sediment loads and mean water discharges at Yadkin River at Yadkin College, 1984-89 


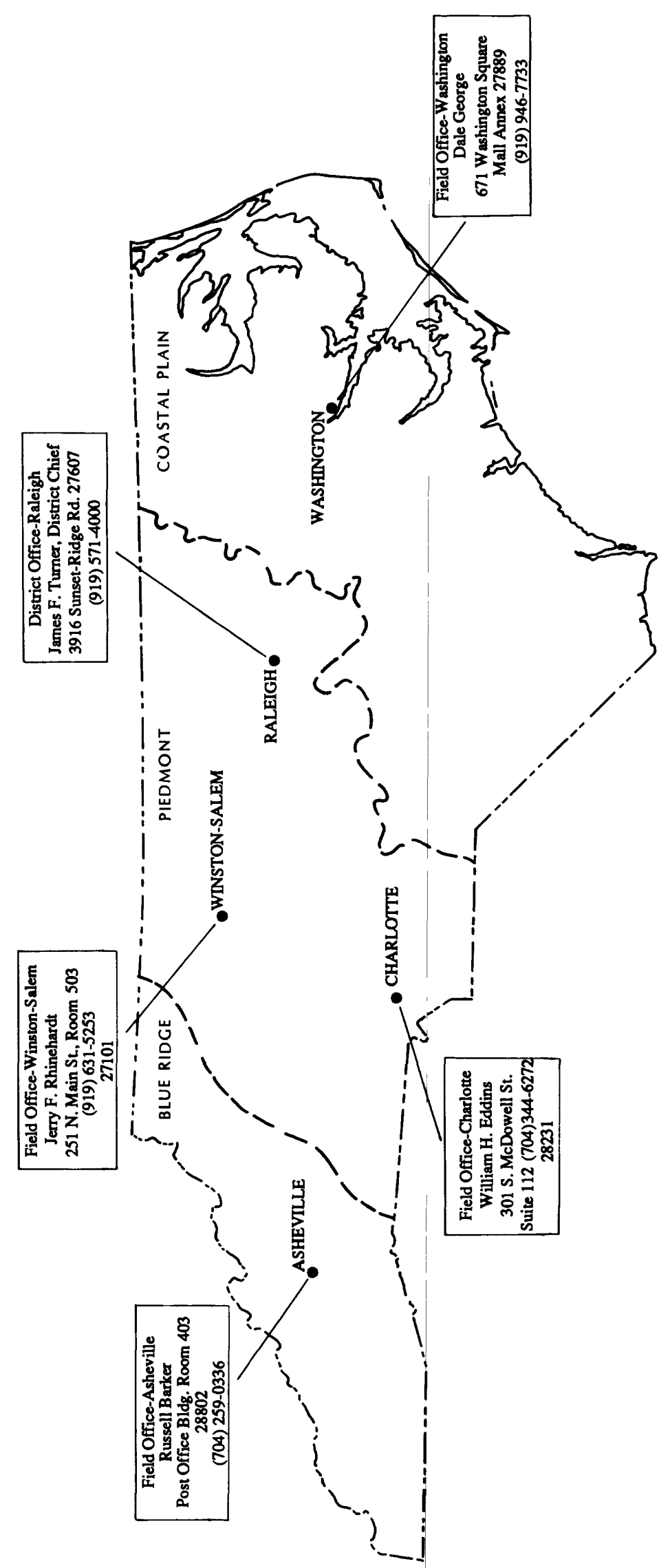




\section{PREFACE}

The U.S. Geological Survey (USGS) was created in 1879 as a bureau of the Department of the Interior by an Act of Congress to oversee the Nation's public lands and to study its mineral resources and geologic structure. Over the ensuing years, the scope of the Survey has expanded to include the study of the Nation's abundant water resources.

Legislation in 1888 authorized the Bureau to survey irrigable lands in arid regions of the Nation, and in 1894, legislation provided funds for gaging streams and determining the Nation's water supply. The need for a comprehensive waterresources information program prompted Congress, in 1928, to enact the Cooperative Matching Program, allowing for cooperative funding for the USGS's waterresources activities with other Federal agencies and State and local governments. In 1964, the scope of the USGS was broadened further to include the responsibility of coordinating all Federal-agency activities in the collection of water data.

The mission of the Water Resources Division of the U.S. Geological Survey is to provide hydrologic information necessary for the management of the Nation's water resources. In order to accomplish this, the USGS in cooperation with other Federal agencies and State and local governments:

- Collects data to determine the quantity, quality, and use of surface and ground water and the quality of precipitation;

- Conducts water-resources investigations and assessments on the national, State, and local levels, characterizes water-resources conditions, and provides the capability to predict the effects of management actions, proposed development plans, and natural phenomena on this natural resource;

- Conducts basic and problem-oriented hydrologic and water-related research useful for the resolution of water-resources problems facing the Nation, States, and local areas;

- Acquires information useful in predicting and delineating water-related natural hazards from flooding, volcanoes, mudflows, and land subsidence;

- Coordinates the activities of all Federal agencies in the acquisition of water data and operates water information centers; 
- Disseminates data and the results of investigations through reports, maps, and other forms of public release;

- Provides scientific and technical assistance in hydrology to other Federal agencies and State and local governments, to licensees of the Federal Energy Regulatory Commission and, on behalf of the U.S. Department of State, to international agencies; and

- Administers the provisions of the Water Resources Research Act of 1984, which include the State Water Resources Research Institute Program (Section 104) and the Water Resources Research Grant Program (Section 105).

The purpose of this report is to describe the water-resources activities of the North Carolina District of the U.S. Geological Survey and to define investigative studies that are currently in progress in the District. An updated list of selected publications is also provided at the back of the report. 


\title{
WATER RESOURCES ACTIVITIES OF THE U.S. GEOLOGICAL SURVEY IN NORTH CAROLINA, 1988-90
}

\author{
Compiled and edited by Rebecca J. Deckard
}

\section{INTRODUCTION}

Stream gaging began in North Carolina in 1895, and in 1921 a District office was established in Asheville. By 1926, water-supply and sewage-disposal problems in the State prompted the District to begin a cooperative streamflow data-collection program.

Although the District's surface-water division was the first to begin a cooperative monitoring program, a ground-water division was established in 1931 to develop a cooperative observation-well program with the State and to investigate the potential for development of a ground-water supply for the Elizabeth City area. The District's surface- and ground-water divisions both continued to expand and develop over the years, and in 1943, the surface-water division of the District moved its office from Asheville to the State capital in Raleigh to be closer to State and Federal cooperators.

In 1944, a water-quality division was added to the District and a laboratory was established on what is now the North Carolina State University campus in Raleigh to analyze the growing number of samples that were being collected at stream-gaging stations across the State. Additional water-quality stations were established across the State, and a statewide cooperative program was developed to study the quality of public surface-water supplies.

With continued growth and expansion of the District's three divisions, the need for a more comprehensive, basin-wide approach to water-resources investigations became evident. In response to this need, the District's surface-water, groundwater, and water-quality divisions merged in 1965 into what is recognized today as the North Carolina District of the U.S. Geological Survey and relocated in Raleigh under the immediate direction of the District Chief.

The North Carolina District consists of the District office in Raleigh and four field offices in Asheville. Charlotte, Washington, and Winston-Salem. Water-resources activities conducted by the District fall under two broad categories: waterresources data and water-resources investigations. 
Water-resources data activities include the systematic collection and processing of data from streamflow, ground-water, and water-quality stations. Data for these stations are stored in the USGS's national WATSTORE computer files located in Reston, Virginia, and are available upon request. Data for selected stations are published annually in a report entitled, "Water Resources Data, North Carolina," as well as in other formal USGS publications.

Water-resources investigations include a wide range of environmental concerns for existing and development-induced conditions. The North Carolina District currently has a number of interpretive studies in progress, the results of which are published in a variety of scientific and technical reports, abstracts, and papers. Reports are provided to cooperating agencies, government depository libraries throughout the State, and various other repositories. A selected list of these reports is found on pages 75--98 of this report.

The USGS conducts water-resources programs in North Carolina in cooperation with State, local, and Federal agencies. These programs are funded through cooperative agreements with the North Carolina Department of Environment, Health, and Natural Resources (DEHNR) (formerly known as the Department of Natural Resources and Community Development), the Department of Human Resources (prior to its incorporation into DEHNR), and the Department of Transportation, as well as a number of city and county governmental agencies. Some indirect support is provided by private enterprise. The USGS also conducts special studies and data-collection programs for the U.S. Army Corps of Engineers, U.S. Environmental Protection Agency, U.S. Marine Corps, U.S. Soil Conservation Service, and the Tennessee Valley Authority. A complete list of USGS cooperators in North Carolina is provided on page 9 of this report.

Water resources in most areas of North Carolina are abundant. However, drought periods during the past several years have revealed that water supplies are not unlimited. Recent controversies regarding eutrophication, synthetic organic chemicals, phosphate detergents, and other stream-quality issues indicate the need for detailed information on the quality of the State's drinkingwater sources.

The ability of the ground-water system to meet future demands is also largely unknown. Withdrawals have produced water-level declines of 150 feet and greater in aquifers throughout large areas of the northeast and central Coastal Plain. The question of the potential for ground water to provide moderate to large water supplies in the Blue Ridge and Piedmont areas is largely unexplored. 
Some water managers and planners consider interbasin transfer a means of meeting future needs in water-poor areas. The hydrologic consequences of such transfers, including freshwater inflow necessary to maintain viable environmental conditions in estuary systems and the effects of proportionately increased waste loading, are not adequately known.

Effects of development on water resources are becoming sensitive issues, particularly in new and expanding urban, industrial, and agricultural areas. Increased flooding potential, deterioration in water quality of streams and ground-water systems from waste disposal, landfill operations, and acid deposition from rainfall are a few examples. In coastal areas, eutrophication of estuary systems from nutrient loading, ecological damage caused by altered patterns of freshwater inflow, declining ground-water levels from overpumping, increased risk of saltwater intrusion, and overdrainage from channelization and dredging projects are of major concern.

Some of the more sensitive, hydrologically oriented environmental concerns in North Carolina are as follows:

- Overstressed ground-water systems statewide;

- Overstressed surface-water supplies statewide;

- Nutrient loading and eutrophication of major estuaries;

- Possible ground-water contamination by waste disposal, induced saltwater intrusion, and other contaminants;

- Possible contamination of surface and ground waters from trace metals and organic substances leaching from landfills and waste-disposal sites;

- Selection and management of waste-disposal sites;

- Effects of acid rainfall on stream systems statewide;

- Loss of resenoir storage due to sedimentation statewide;

- Regional water supplies--toxic materials (inflow) and resuspension of synthetic organic compounds; and

- Pesticide/herbicide migration into streams and ground water.

Priority issues of Federal, State, and local interest for the 1990 fiscal year water-resources program are as follows:

$\checkmark$ Ground-water quality

$\checkmark$ Water supply and wastewater disposal

$\checkmark$ Stream quality

$\checkmark$ Hydrologic hazards 


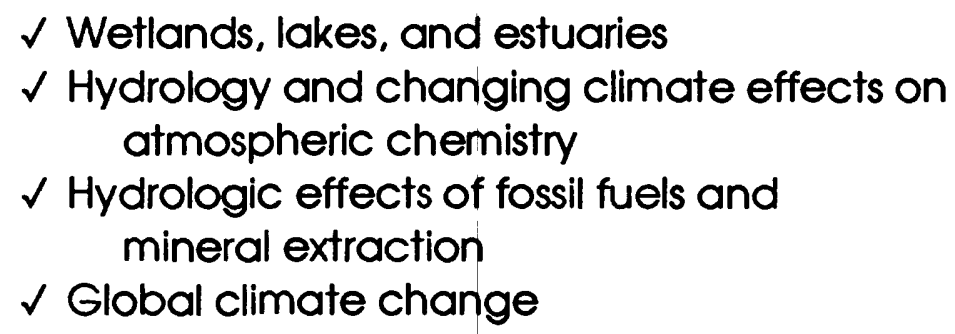

The hydrologic-data program continues to provide the foundation of ongoing and future interpretive investigations in North Carolina and the Nation. The data program is a high priority effort in the Federal-State Cooperative Program.

The 1988-90 program of the North Carolina District, in cooperation with other Federal agencies and State and local governments, addresses most of these issues and North Carolina's need for water-resources information. A summary of the program for fiscal year $1989-90$ is described in following sections of this report.

The North Carolina District also is participating in investigations of national scope, such as the USGS National Water-Quality Assessment Program (NAWQA) and the Appalachian-Piedmont Regional Aquifer Systems Analysis (APRASA) programs. Because of growing concerns about current conditions, trends, and factors that affect the quality of the Nation's water resources, Congress appropriated funds in 1986 for the USGS to begin a NAWQA pilot program.

Based on results of the NAWQA pilot program, it was determined that implementation of the NAWQA program was in the best interest of the Nation and that the USGS was well qualified to establish and implement the program. Sixty study units were designated to investigate ground-and surface-water quality within stream-aquifer systems covering about 45 percent of the land area of the United States. These study-unit investigations will address regional and local water-quality concerns and will provide a unified framework on which to assess regional and national water quality. The North Carolina District serves as headquarters for the study-unit investigation of the Albemarle-Pamlico drainage area.

Regional and national water-quality concerns addressed by the NAWQA program are:

$\checkmark$ Occurrence and concentration of pesticides in ground and surface water and their relation to human and aquatic health criteria; 
$\checkmark$ Relation of the presence of pesticides in ground and surface water to application rates, cropping practices, and climatic, geologic, and soil factors:

$\checkmark$ Relative magnitude of various point- and nonpoint-souce contributions for different types of ground-and surface-water contamination;

$\checkmark$ Effects of agricultural management practices on ground-and surface-water quality:

$\checkmark$ Regional occurrence and concentration of trace elements and industrial organic compounds in ground and surface water; and

$\checkmark$ Effects of changes in municipal wastewater-treatment practices on water quality and ecosystem health.

Study-unit investigations are scheduled to include 4 to 5 years of continuous and intensive data collection and analysis followed by 5 years of less intensive assessment activities. These investigations are to be conducted through the year 2002.

\section{SOURCES OF FUNDS}

Funds to support U.S. Geological Survey water-resources activities in North Carolina are derived from three principal sources.

- Federal Program--Funds for the Federal Program are appropriated by the Congress and are specifically identified in the Survey's annual budget. These funds are used to support research, data collection, high-priority topical programs (such as NAWQA), the coordination of all Federal programs related to collection of water data, and internal support services.

- Federal-State Cooperative Program--Federal funds are appropriated by the Congress and used to match those furnished by State and other tax-supported agencies on a 50-50 basis. These funds are used for a variety of hydrologic data-collection activities and water-resources investigations in which the USGS represents Federal interests and the cooperating agencies represent State and local interests. 
- Other Federal Agencies (OFA) Program--Funds in this program are transferred to the USGS as reimbursement for work performed at the request of another Federal agency.

Additional sources of funds include unmatched reimbursable funds from State and local government agencies and Federal Energy Regulatory Commission licensees.

The proportion of funding for major programs conducted by the North Carolina District in fiscal year 1989 (October 1, 1988 through September 30, 1989) is shown in figure 1.

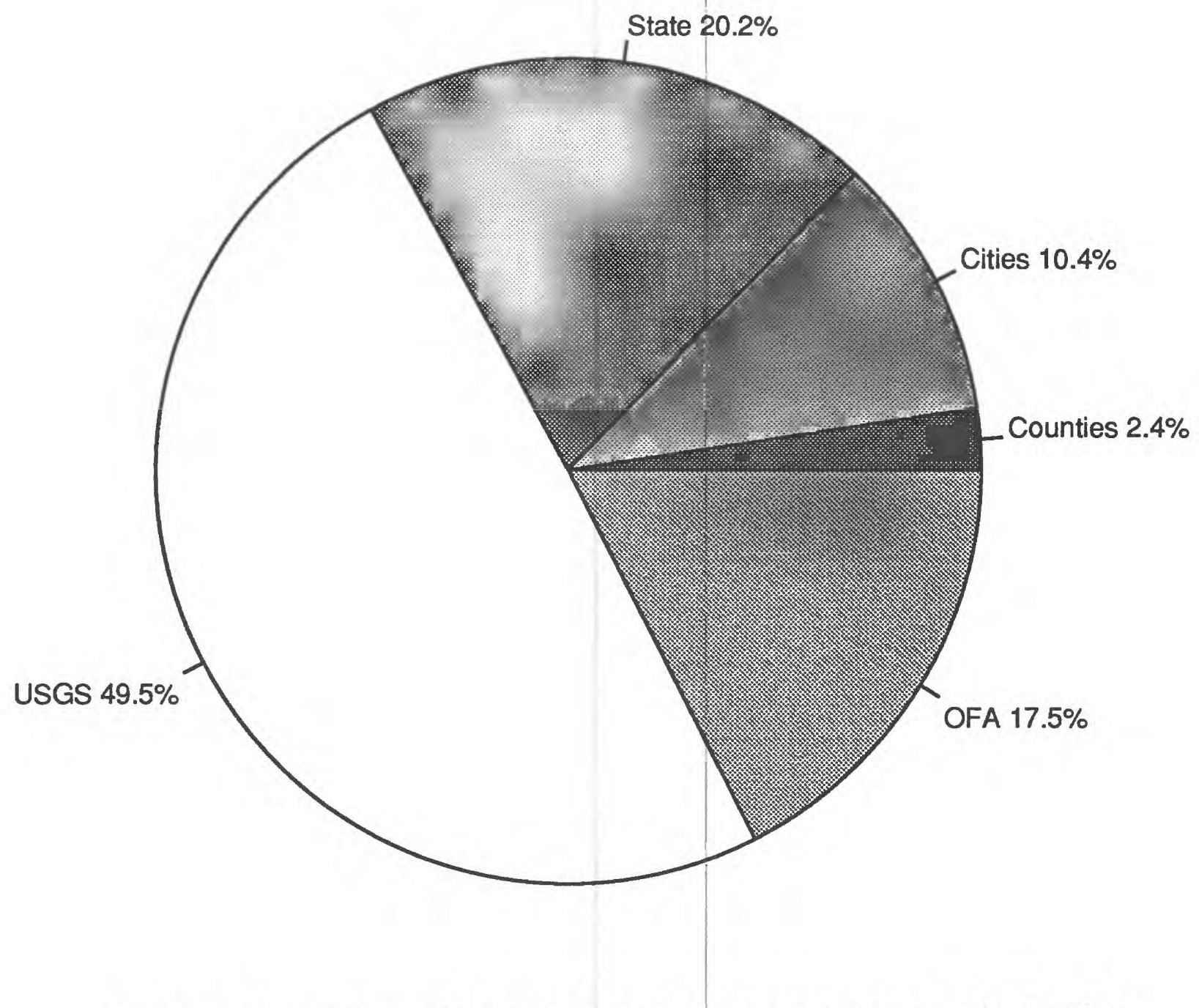

Figure 1.--Proportion of funding for major programs conducted by the North Carolina District in fiscal year 1989. 


\section{COOPERATING AGENCIES}

In 1988-90, the USGS conducted programs in cooperation with 7 State, 43 local, and 10 Federal agencies. Following is a list of USGS cooperators in North Carolina during that period.

\section{State Agencies}

North Carolina Department of Environment, Health, and Natural Resources

Division of Water Resources

Albemarle-Pamlico Estuarine Study

Division of Environmental Health

Division of Environmental Management

North Carolina Department of Transportation

North Carolina State University Agricultural Extension Service

\begin{tabular}{cc}
\multicolumn{2}{c}{ Local Agencies } \\
Chatham County & City of Lexington \\
Currituck County & City of New Bern \\
Forsyth County & City of Raleigh \\
Greene County & City of Rocky Mount \\
Guilford County & Town of Apex \\
Jones County & Town of Ayden \\
Mecklenburg County & Town of Bethel \\
New Hanover County & Town of Carrboro \\
Onslow County & Town of Cary \\
Orange County & Town of Chapel Hill \\
City of Ashevile & Town of Farmville \\
City of Brevard & Town of Hillsborough \\
City of Charlotte & Town of La Grange \\
City of Durham & Town of Pinetops \\
City of Fayetteville & Town of Pittsboro \\
City of Greensboro & Town of Sanford \\
City of High Point & Town of Smithfield \\
City of Jacksonville & Town of Snow Hill \\
City of Kinston & Town of Statonsburg \\
Greenville Utilities
\end{tabular}

Triangle Area Water-Supply Monitoring Project Steering Committee 


\section{Federal Agencies}

Department of the Navy, U.S, Marine Corps

Federal Emergency Management Agency

Federal Energy Regulatory Commission

Federal Highway Administration

Tennessee Valley Authority

U.S. Army Corps of Engineers

U.S. Department of Agriculture, Agricultural Research Service

U.S. Department of Agriculture, Soil Conservation Service

U.S. Environmental Protection Agency

U.S. Fish and Wildlife Service

\section{DISTRICT ORGANIZATION}

The North Carolina District consists of two operating sections, Hydrologic Records and Hydrologic Studies, and three support units. Administrative Services, Publications, and Computer Services (fig. 2). The District's water-resources investigations are conducted by both operating sections with an assigned project chief responsible for overseeing each investigation. Additional support is available to the District from USGS research centers, laboratories, technical consultants, and training centers throughout the United States.

Activities of the Hydrologic Records Section include the collection, processing, and publication of records from statewide surface-water, groundwater, and water-quality monitoring networks. This operating section also prepares interpretive reports on regionalization of streamflow characteristics. sedimentation, stream quality, effects from various land-management practices, channelization effects, urban hydrology, and flood mapping, in addition to processing numerous requests for information.

Activities of the Hydrologic Studies Section include proposing, planning, and conducting water-resources investigations describing the occurrence, availability, and physical, chemical, and biological characteristics of surface-and ground-water resources in North Carolina. Examples of some types of investigations conducted by the Studies Section are: effects of ground-water development; saltwater encroachment; effects of waste disposal on the ground-water system; ground-water supply potential; ground-water use; aquifer mapping: effects of hazardous-waste disposal; aquifer characteristics and effects of hydraulic stress upon various aquifer systems; sediment, stream-quality, and biologic conditions; acid deposition; effects of landfills on ground- and 
ORGANIZATIONAL CHART OF THE NORTH CAROLINA DISTRICT

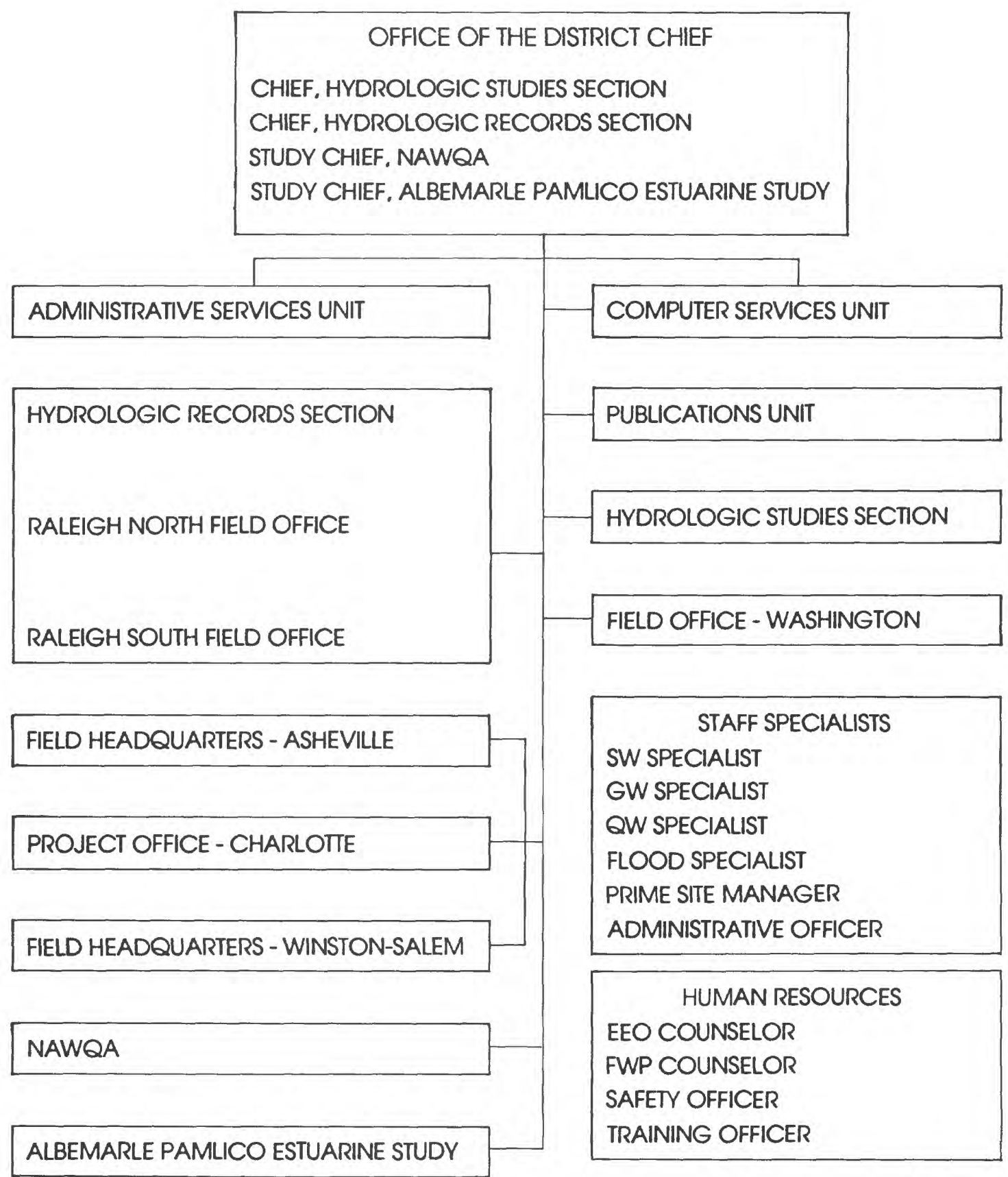

Figure 2.--Organizational chart for the North Carolina District. 
surface-water systems; urban hydrology; and channelization effects. Many of these studies involve the development, calibration, and use of digital simulation models as a means of evaluation. Digital models are also used for hydrologic mapping and design of monitoring networks.

The Administrative Services Unit provides financial management, personnel and procurement services, management analysis and improvement services, and general office support.

The Publications Unit provides overall support in the planning, management, and production of reports. Unit personnel provide assistance to project and section chiefs in the planning, design, and preparation of reports and manuscripts, assuring adherence to Division policy and technical and editorial quality.

The Computer Services Unit provides complete data-processing and related support services, such as data transcription, programming support, and systems analysis. Unit personnel operate and maintain the computer facilities for the District and provide technical assistance to the project staff on the implementation and execution of various digital models, data-base programs, and software required for hydrologic analysis.

Plans for District reorganization and relocation are in progress. District reorganization will provide for expansion to include three primary operating sections: (1) Hydrologic Studies Section, (2) Hydrologic Records Section, and (3) Management Operations Section; and three study units: (1) Albemarle-Pamlico Study Unit, (2) NAWQA Study Unit, and (3) North Carolina Ecology Group. The District will continue to provide discipline-specialist expertise in ground water, surface water, and water quality. Relocation plans are for the District office to move to a new building located at 3916 Sunset Ridge Road, located west of downtown Raleigh. The relocation is scheduled to be complete by the end of the first quarter of fiscal year 1991.

\section{WATER-RESOURCES DATA}

Water-resources data activities include the routine collection and processing of data from streamflow, ground-water, water-quality, and sediment stations located across the State. Data for these stations are processed, analyzed, and stored in the USGS National Water Data Storage and Retrieval System (WATSTORE) in Reston, Virginia, and are available upon request for a minimal fee plus computer costs incurred in producing the end product. Data for selected stations 
are published in an annual report entitled, "Water-Resources Data, North Carolina, Water Year 19_," as well as in other publications of the USGS. This section briefly summarizes District data-collection activities for the period 1988-90.

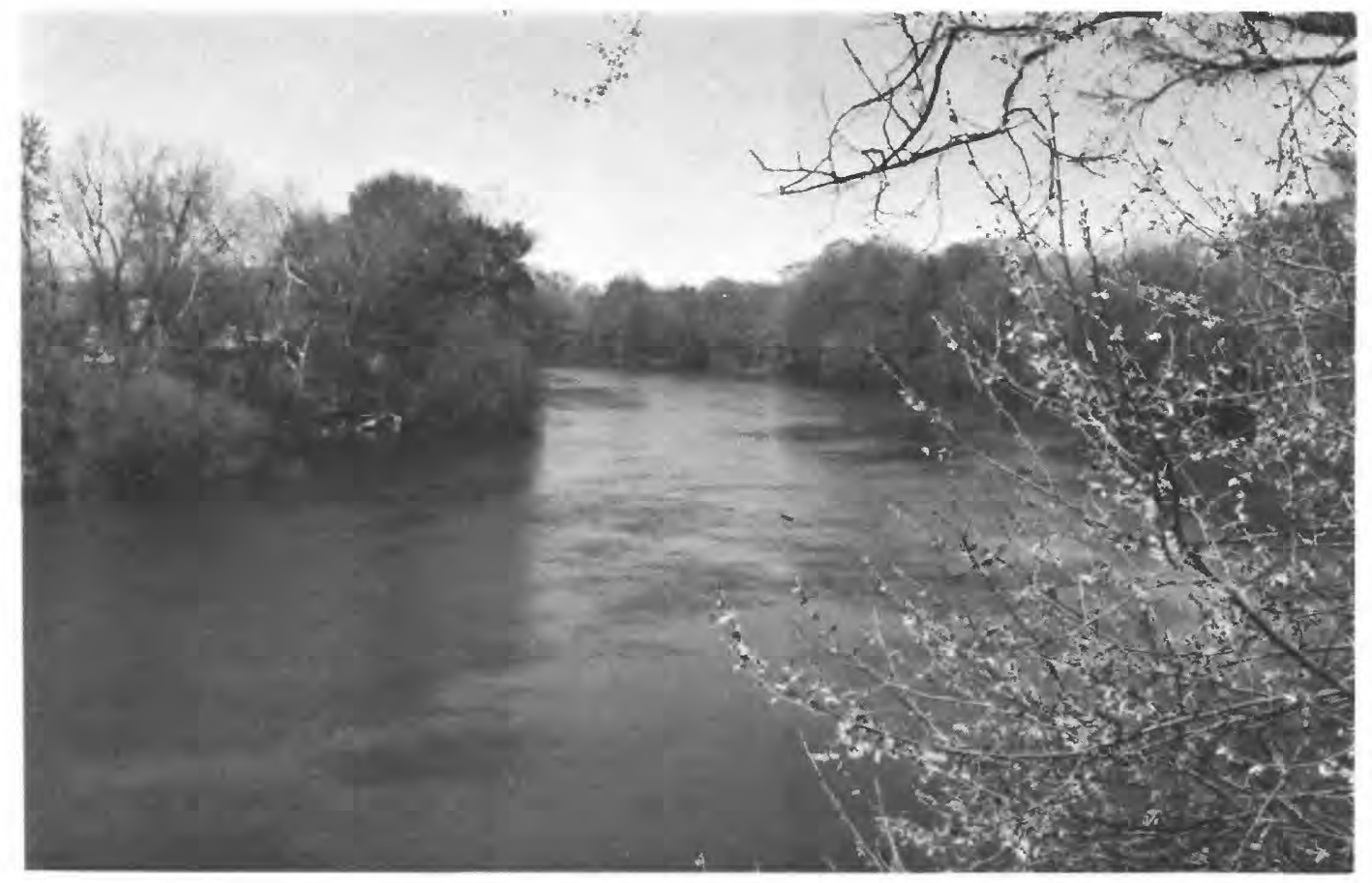

The Neuse River at Kinston, North Carolina.

(Photograph by T.K. Manning, U.S. Geological Survey, Raleigh, North Carolina) 
Prolect: Streamflow network in North Carolina (NCOO1)

Location: Statewide

Project Chief: H.C. Gunter

Period of Project: Continuous since 1927

Cooperation: Federal, State, local

Problem: An appropriate surface-water data base is necessary to provide information for the purposes of surveillance, planning, design, hazard warning, and operation and management in water-related fields, such as water supply, hydroelectric power, flood control, irrigation, bridge and culvert design, wildlife management, pollution abatement, flood-plain management, and water-resources development.

Objectives: To collect (1) surface-water data sufficient to satisfy needs for current uses, such as assessment of water resources, operation of reservoirs or industries, forecasting, disposal of wastes and pollution controls, discharge data to accompany water-quality measurements, compact and legal requirements, and research or special studies; and (2) data necessary for analytical studies to define the statistical properties of, and trends in, the occurrence of water in streams, lakes, and estuaries for use in planning and design.

Approach: Standard methods of data collection are used as described in the USGS publication series, "Techniques of Water-Resources Investigations of the United States Geological Survey." Partial-record gaging will be used instead of complete-record gaging where it serves the required purpose. Locations of the 1989 network stations are shown in figure 3.

Progress: Hydrologic data for continuous record, reservoir, and partial-record surface-water stations in the State were collected and published under the general supenvision of the District office. One station was added in cooperation with the City of Lexington, and four were added in cooperation with the City of Raleigh. Two stations operated in cooperation with the State were retained from the baseline water-quality network. 


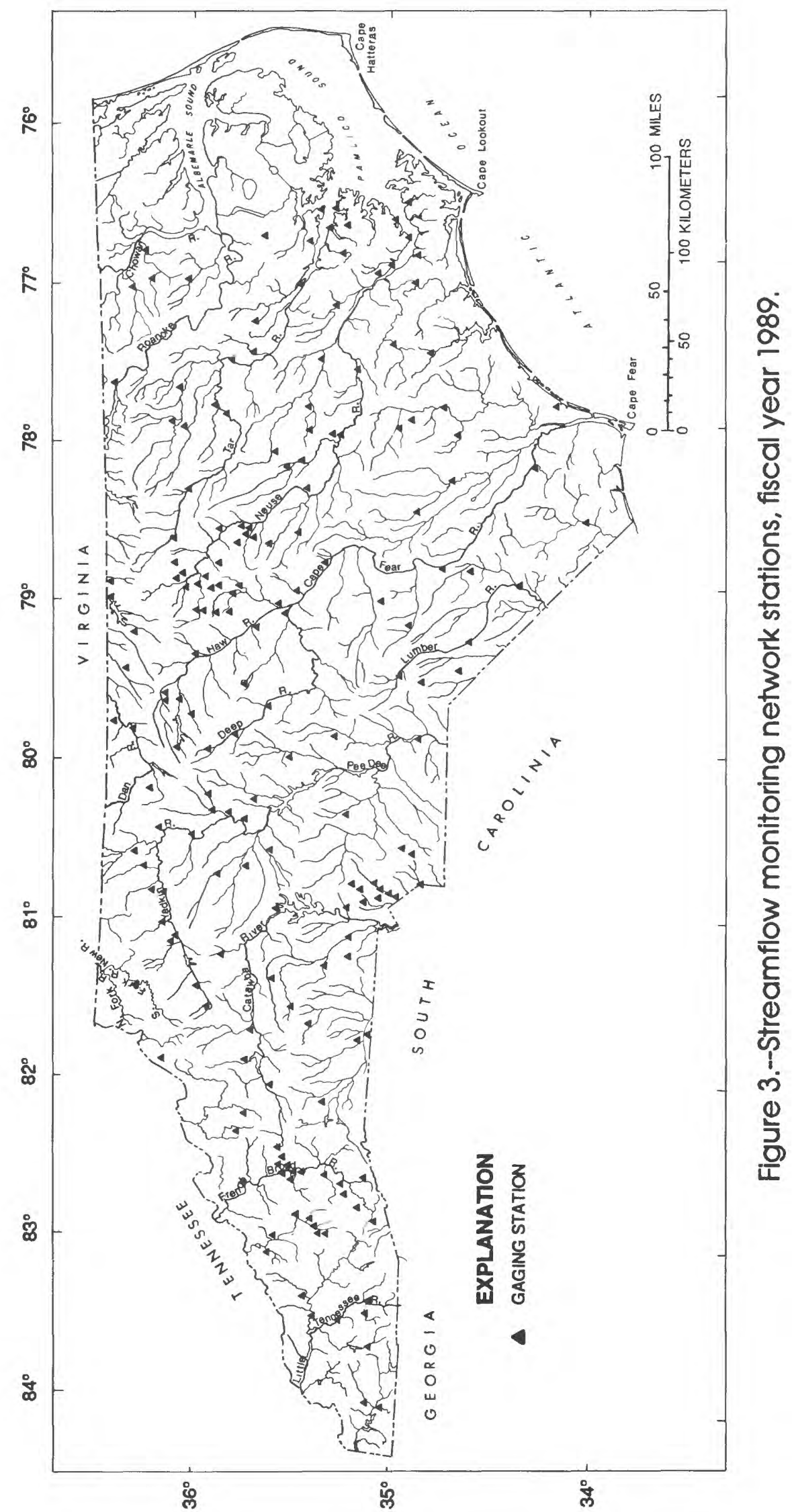


Prolect: Ground-water program in North Carolina (NCO02)

location: Statewide

Prolect Chiefs: R.W. Coble and A.G. Strickland

Period of Project: Continuous since 1943

Cooperation: Federal and State

Problem: Long-term water-level records are needed to evaluate the effects of climate on continuous discharge from and periodic recharge to the groundwater system to provide a data base from which to measure the effects of development and to provide data for management of the resource.

Objectives: To collect, analyze, and publish water-level records for North Carolina. These records provide a long-term data base for evaluating general responses of the hydrologic system to natural climatic variations and induced stresses; known and potential problems can be defined early enough to allow proper planning and management.

Approach: Evaluation of regional hydrogeology allows broad, general definition of aquifer systems and their boundary conditions. Within this framework and with knowledge of the stresses on the systems, the best locations for observation wells are selected to detect short- and long-term system behavior. The network of wells is improved as records become available and detailed areal studies of the ground-water system more closely define the aquifers, their properties, and the stresses to which they are subjected. Locations of wells in the 1989 program are shown in figure 4.

Progress: During 1988-90, continuous and periodic water-level records were obtained from 54 wells in the joint USGS/DEHNR ground-water observationwell program. Water-level records from the Piedmont and Blue Ridge areas of the State will be improved with the planned construction of two new wells designed to measure climatic effects on ground-water storage. In the fall of 1988, synoptic measurements were made in over 100 wells in the southern Coastal Plain to construct potentiometric-surface maps of the stressed Black Creek and upper Cape Fear aquifers.

\section{Report:}

Coble, R.W., Strickland, A.G., and Bailey, M.C., 1989, Ground-water level data for North Carolina - 1987: U.S. Geological Survey Open-File Report 89-68, 152 p. 


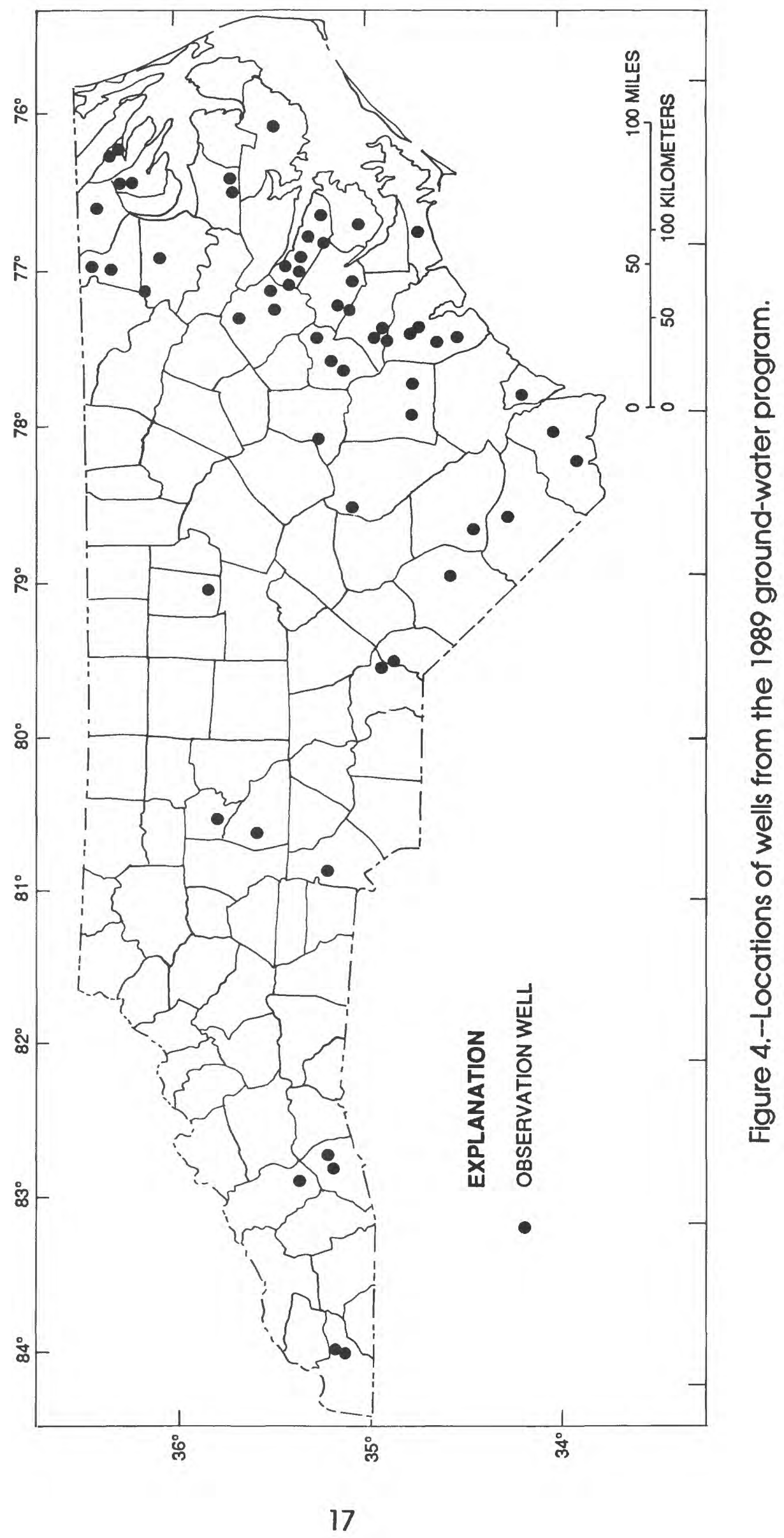


Project: Water-quality network in North Carolina (NCOO3)

Location: Statewide

Prolect Chief: T.K. Manning

Period of Project: Continuous since 1943

Cooperation: Federal

Problem: Water-resource planning and water-quality assessment require a nationwide base of standardized information. For intelligent planning and realistic assessment of the water resource, the chemical and physical quality of the rivers and streams must be defined and monitored.

Objectives: To provide a national bank of water-quality data for broad State and Federal planning and action programs and to provide data for Federal management of interstate and international waters.

Approach: Operation of a network of water-quality stations to provide average chemical concentrations, loads, and time trends as required by planning and management agencies. This network presently consists of the National Stream Quality Accounting Network (NASQAN) and the Hydrologic Benchmark Network (HBMN). Locations of 1989 network stations are shown in figure 5.

Progress: Data collection at the eight NASQAN sites and one benchmark site was done according to NASQAN guidelines with an emphasis toward collecting samples at varying flow conditions. 


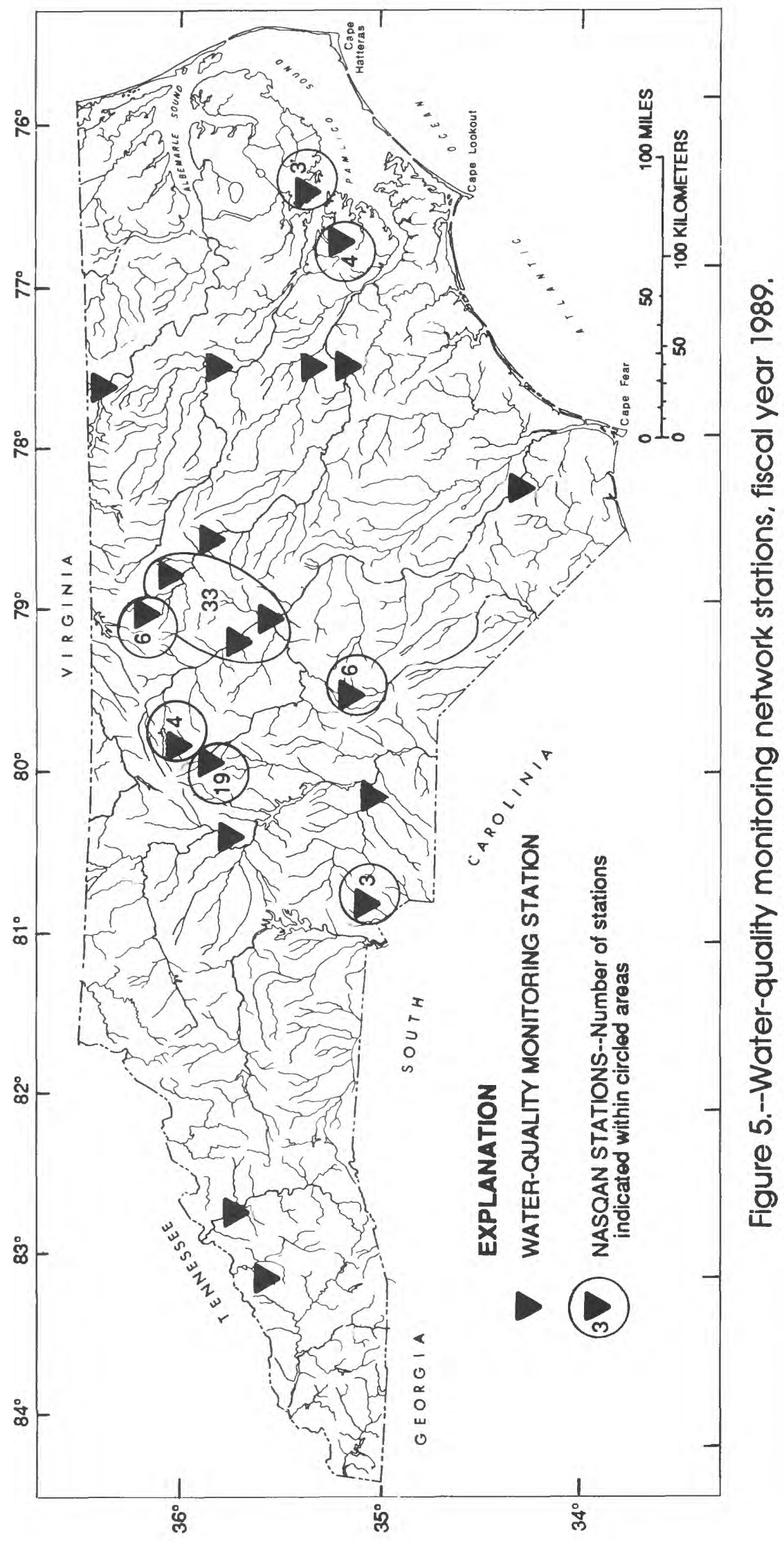




\section{WATER-RESOURCES CONDITIONS}

Drought conditions prevailed over North Carolina during most of the 1988 water year (October 1987-September 1988). The trend of below-normal rainfall that began in 1985 continued in all areas except for coastal regions. As a result, record-low monthly and daily streamflow occurred in the central and western parts of the State, generally during the spring and summer. Managers of several municipal surface-water supply systems in these areas issued mandatory or voluntary water-use restrictions. The lack of rainfall resulted in record-low annual streamflow at many long-term stations in central and western North Carolina, as indicated in the following table:

\begin{tabular}{lc|ccc}
\hline \multicolumn{1}{c}{ Station name } & \multicolumn{2}{c}{$\begin{array}{c}\text { 1988 annual } \\
\text { mean discharge, } \\
\text { in cubic feet } \\
\text { Years of } \\
\text { record }\end{array}$} & $\begin{array}{c}\text { Previous lowest } \\
\text { annual mean } \\
\text { discharge, in cubic } \\
\text { feet per second, } \\
\text { and year }\end{array}$ \\
\hline Deep River near Moncure & 58 & 606.0 & 629.0 & 1981 \\
Jacob Fork at Ramsey & 27 & 23.8 & 30.7 & 1981 \\
Indian Creek near Laboratory & 37 & 40.4 & 42.2 & 1955 \\
First Broad River near Casar & 29 & 43.4 & 54.9 & 1981 \\
South Fork New River near Jefferson & 64 & 233 & 247 & 1956 \\
Davidson River near Brevard & 68 & 70.6 & 71.2 & 1981 \\
French Broad River at Blantyre & 68 & 534 & 561 & 1981 \\
Mills River near Mills River & 57 & 86.8 & 92.1 & 1926 \\
French Broad River at Asheville & 93 & 1.004 & 1.114 & 1981 \\
East Fork Pigeon River near Canton & 34 & 71.9 & 76.6 & 1986 \\
South Toe River near Celo & 31 & 79.4 & 96.1 & 1986 \\
Watauga River near Sugar Grove & 49 & 84.7 & 103 & 1956 \\
Valley River near Tomotla & 76 & 111 & 115 & 1941 \\
\hline
\end{tabular}

Large areas of North Carolina received less-than-normal rainfall in May 1988. The lack of rain accelerated the normal seasonal decline in streamflow to the lowest discharge ever recorded in May at the French Broad River at Asheville (fig. 6). However, sufficient amounts of rain fell in many central Piedmont and southern Coastal Plain counties to sustain normal streamflow in those areas. 


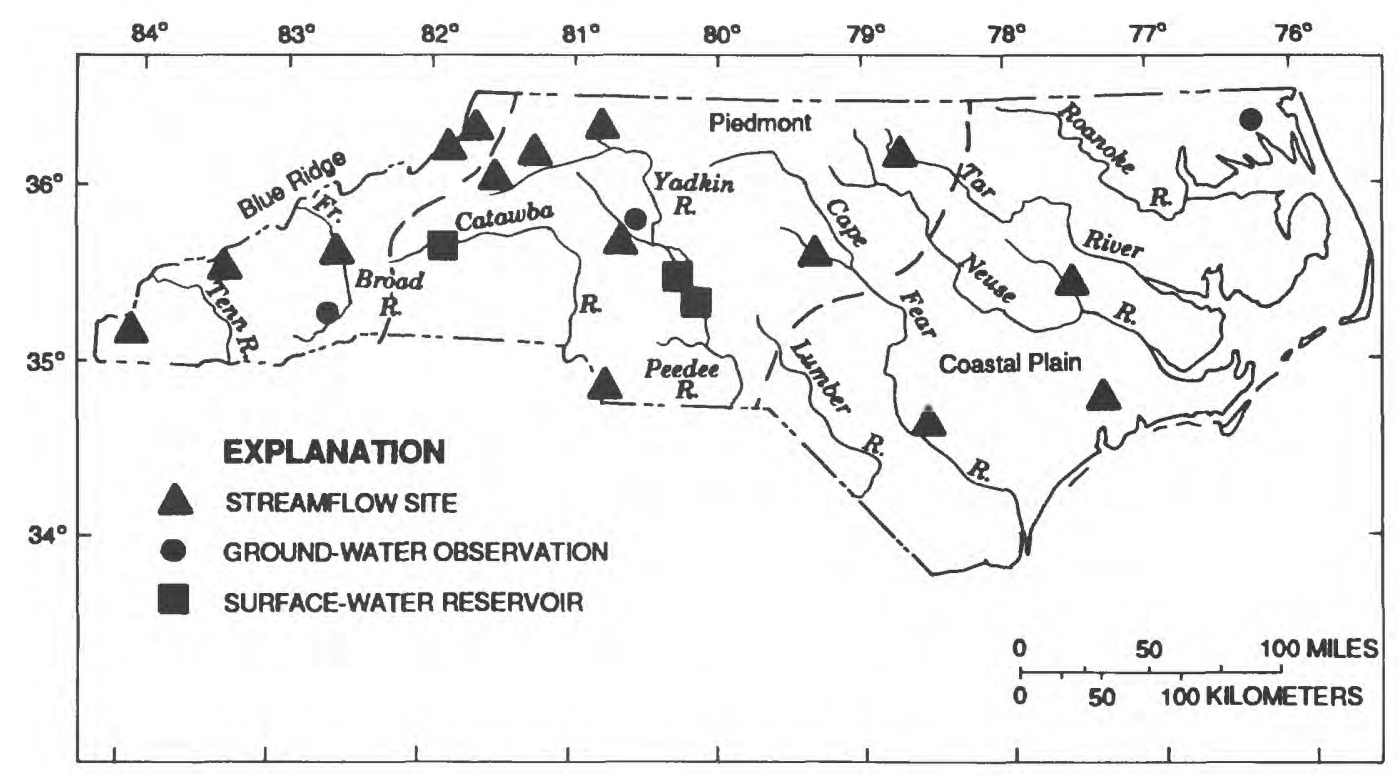

Figure 6.-Selected index stations in the streamflow, ground-water, and water-quality monitoring programs.

During June and July 1988, record-low monthly flow was again recorded for many Blue Ridge and southern Piedmont streams, and the declining water levels of numerous municipal water-supply reservoirs prompted system managers to impose voluntary or mandatory water-use restrictions. During August, the eastern Blue Ridge and the entire northern half of the State again received less-thanaverage rainfall. The lowest flow of many Blue Ridge and Piedmont rivers for the water year was recorded by mid-month. By that time, a total of 20 municipal water-supply systems across North Carolina had imposed water-use restrictions. Rainfall from the remnants of Tropical Storm Chris contributed to the return to normal conditions in the southeast. Elsewhere in North Carolina, where thundershowers produced more abundant rainfall, water-use restrictions were eased or lifted from several municipal surface-water supply systems.

Although precipitation during the fall of 1988 and through January 1989 remained below average across the State, most areas received near- or aboveaverage rainfall during the remainder of 1989. Annual rainfall totals for 1989 exceeded the average by as much as 12.05 inches in Raleigh and 10.38 inches in Asheville (fig. 7). 

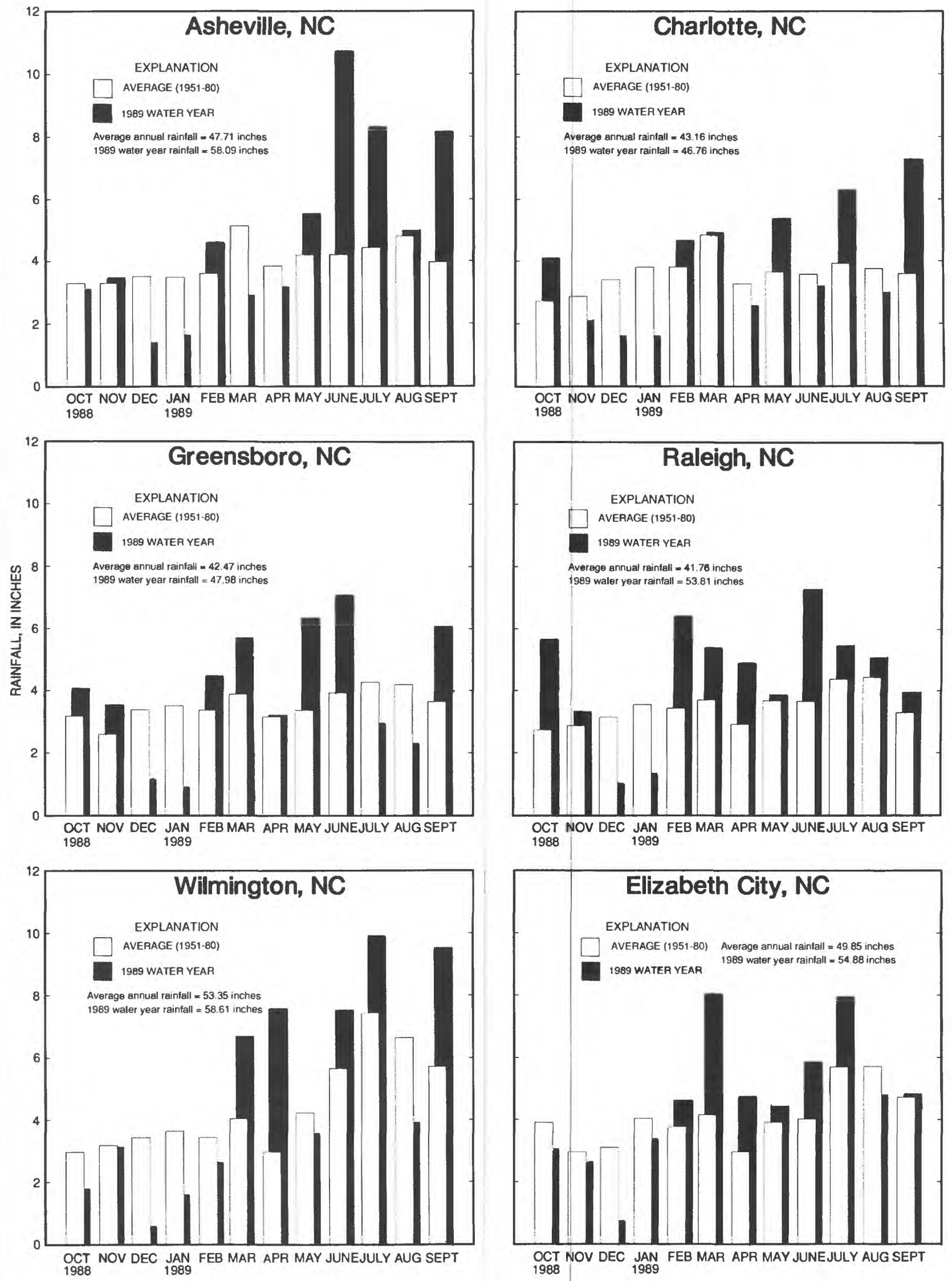

Figure 7.-Monthly rainfall for 1989 water year and average monthly rainfall for period 1951-80 (from NOAA climatological reports). 
In contrast to 1988 drought conditions, extreme rainfall events occurred several times during water year 1989. On July 3-4, heavy rains fell in the Linville River and upper French Broad River basins, resulting in flash floods that caused two drowning deaths and damaged several bridges and roads. Local flooding also occurred on July 16 in the northeastern Piedmont and northwestern Coastal Plain and on July 21-23 near Boone in the northern Blue Ridge Province. More than 8 inches of rain fell on Fayetteville on September 15, causing floods that resulted in two drowning deaths, several earthen dam failures, and damages that totaled more than $\$ 10$ million. Tropical Storm Hugo, following a path from Charlotte north through the western Piedmont and northern Blue Ridge, brought heavy rains to those regions on September 22-23. Streams in that area experienced significant flooding, with recurrence intervals ranging from less than 5 years to 20 years at Watauga River near Sugar Grove.

Ground-water levels in unconfined (water-table) aquifers fluctuated during the 1989 water year as a result of discharge from ground-water reservoirs to streams and periodic recharge from rainfall. The water level in the Piedmont obsenvation well reached record-high levels several times during the year. Water levels in the Blue Ridge observation well indicated complete recovery from the long period of water-level decline that began in March 1988 and remained above average from June through September 1989. The water level in the Coastal Plain obsenation well was near record high late in December 1988 and reached a record high near the end of February 1989, remaining above average throughout the remainder of the water year (fig. 8).

Ground-water withdrawals in the Coastal Plain Province have resulted in declining water levels in some of the confined aquifers for a number of years. This declining trend indicates that some of the water pumped from those aquifers is coming from ground-water storage and that withdrawals are not being completely replenished by increased recharge and(or) by a decrease in natural discharge. An example of this trend is illustrated by the hydrograph of well NC-44 at the City of New Bern well field at Cove City (fig. 9) where water has been withdrawn from the Black Creek and upper Cape Fear aquifers since 1968.

During periods of deficient rainfall, ground-water constitutes a larger component of streamflow; therefore, the mineral content of many streams in North Carolina was somewhat higher during the 1988 water year. Concentrations of major dissolved constituents, such as chloride, sodium, and calcium, were approximately 10- to 100-percent higher in 1988 than in 1987 for the streams sampled. 

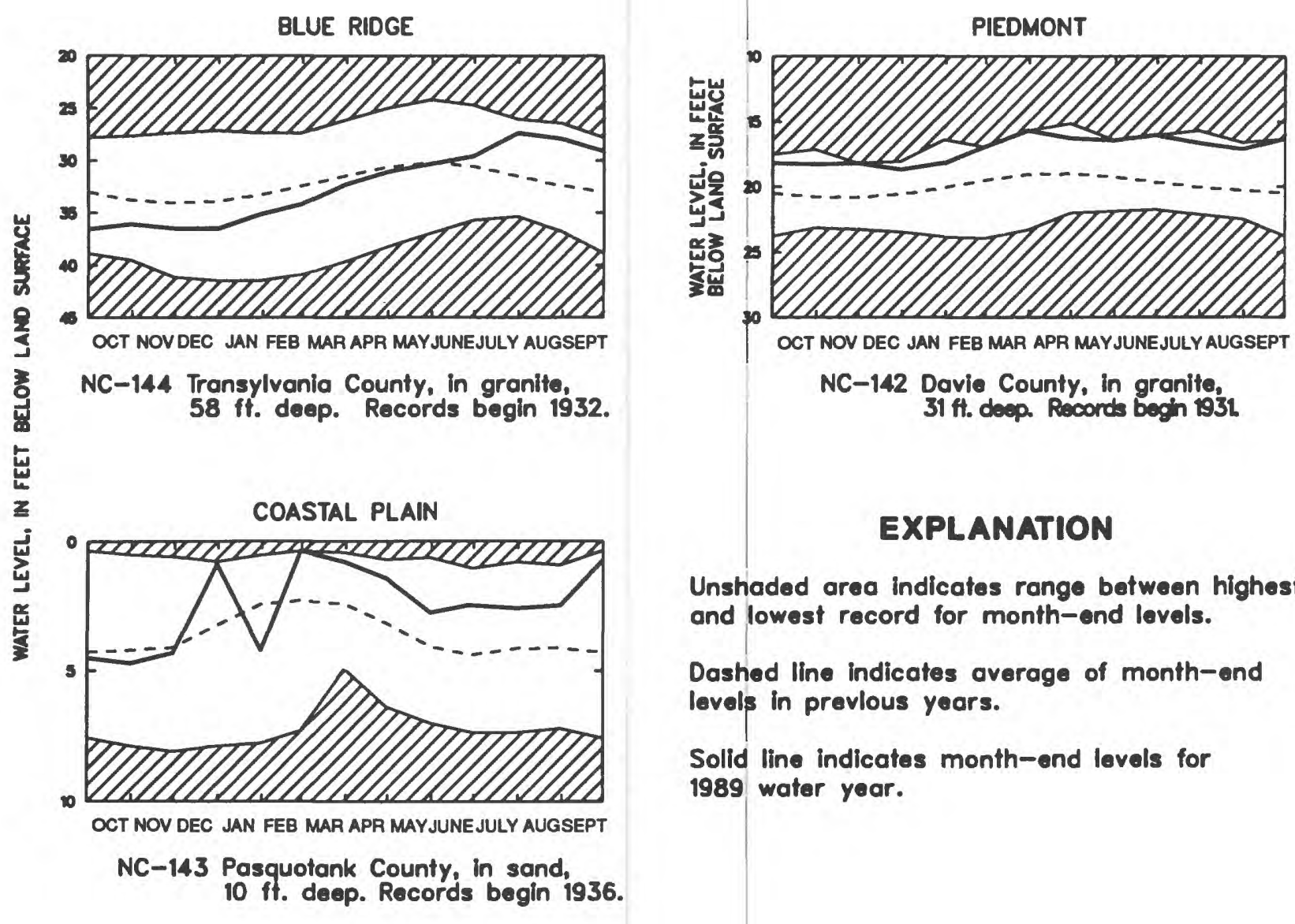

\section{EXPLANATION}

Unshaded area indicates range between highest and lowest record for month-end levels.

Dashed line indicates average of month-end levels in prevlous years.

Solid line indicates month-end levels for 1989 water year.

Figure 8.-Variation of water levels at selected long-term observation wells for the 1989 water year in the Blue Ridge, Piedmont, and Coastal Plain Provinces of North Carolina. 


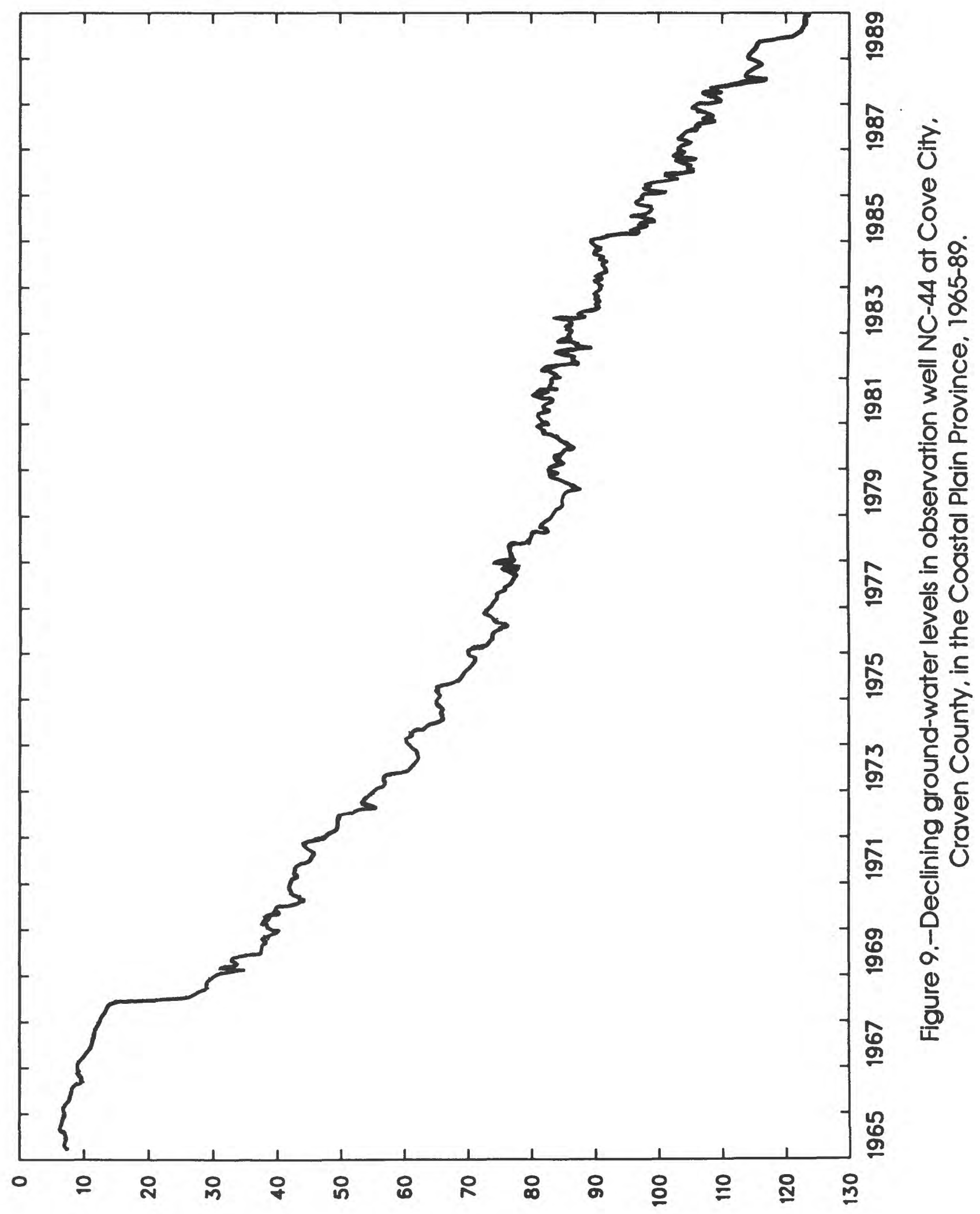

$\exists כ \forall J Y \cap S$ ON 
Specific conductance, which is related to the concentration of dissolved ionic constituents and is often used to estimate dissolved-solids concentrations, was meaured daily in the Yadkin River at Yadkin College. The variations of the monthly and annual means of specific conductance at this site for the year and for the reference period $1975-89$ are shown in figure 10 . The monthly mean specific conductance in the Yadkin River was above the long-term average for each month during the water year.

Daily concentrations of suspended sediment in the Yadkin River at Yadkin College, also a long-term sediment station, are used to define trends. The sediment-transport load for the 1989 water year ( 996,600 tons) was approximately 110 percent of the long-term average annual load for the reference period 195189 ( 890,400 tons) (fig. 11$)$ and was approximately 9 times greater than the annual load for the 1988 water year as a result of increased streamflow at that site during the water year. The annual mean discharge for the 1989 water year was 1.6 times greater than the annual mean discharge for the 1988 water year.

Specific conductance is generally inversely proportional to streamflow, with highest values occurring during base flow when streamflow is principally derived from ground-water discharge. Conversely, sediment concentrations are generally directly proportional to streamflow, with the higher sediment concentrations occurring during a rise in streamflow. The slightly higher specificconductance values and record low sediment load in the Yadkin River at Yadkin College in the 1988 water year were the result of the unusually low streamflow at the site. Annual mean discharge at this site was the fourth lowest for the period of record (1928-88). The maximum mean daily discharge in the 1988 water year at this site was 6,930 cubic feet per second, which is the lowest 1-day maximum for the period of record. In addition, the 3-, 7-, 15-, and 30-day maximum average flows all ranked second lowest for the period of record. These low streamflow conditions in 1988 resulted in higher specific-conductance values and lower sediment-transport loads. 


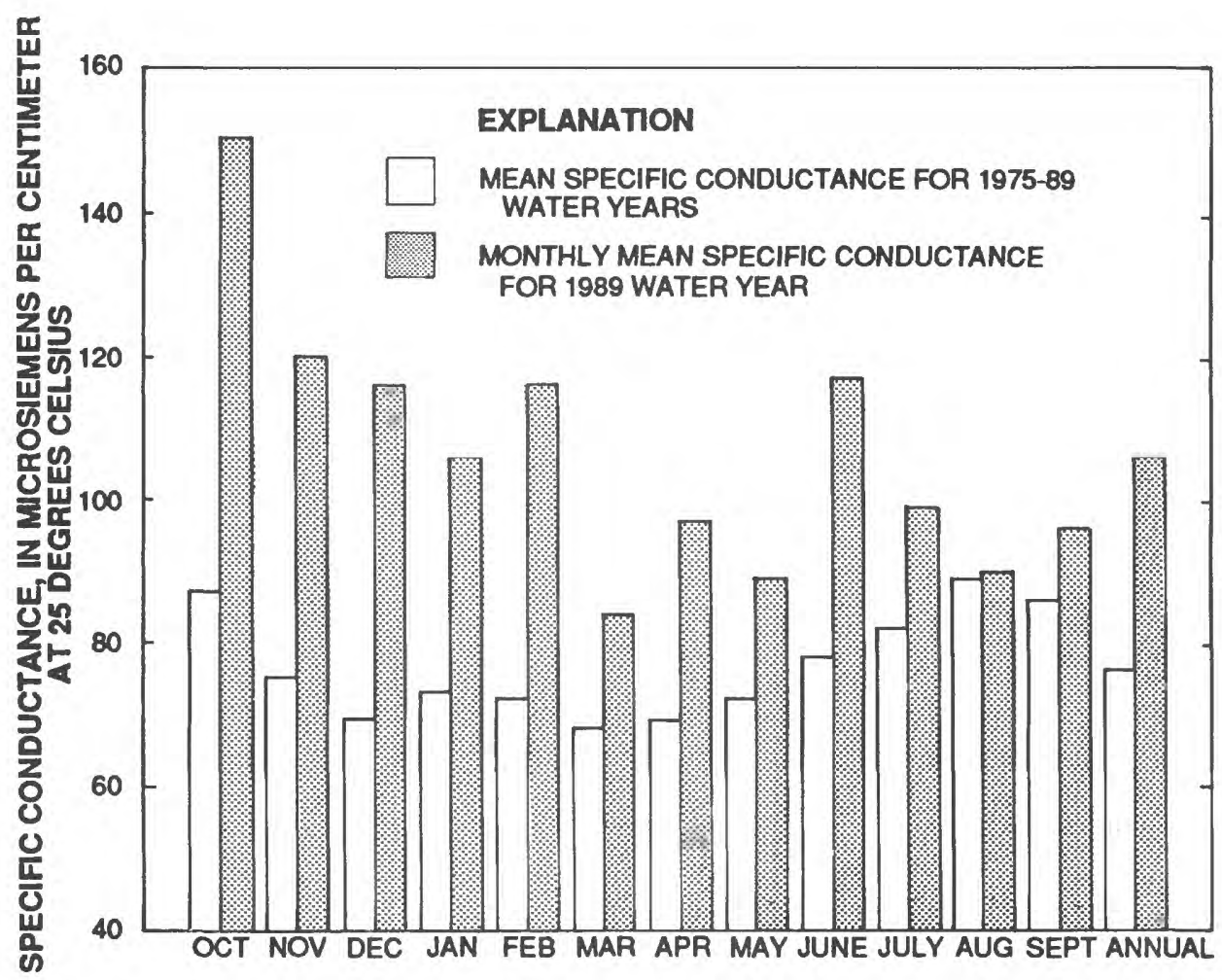

Figure 10.--Specific conductance at Yadkin River at Yadkin College during the 1989 water year and mean specific conductance for the period 1975-89.

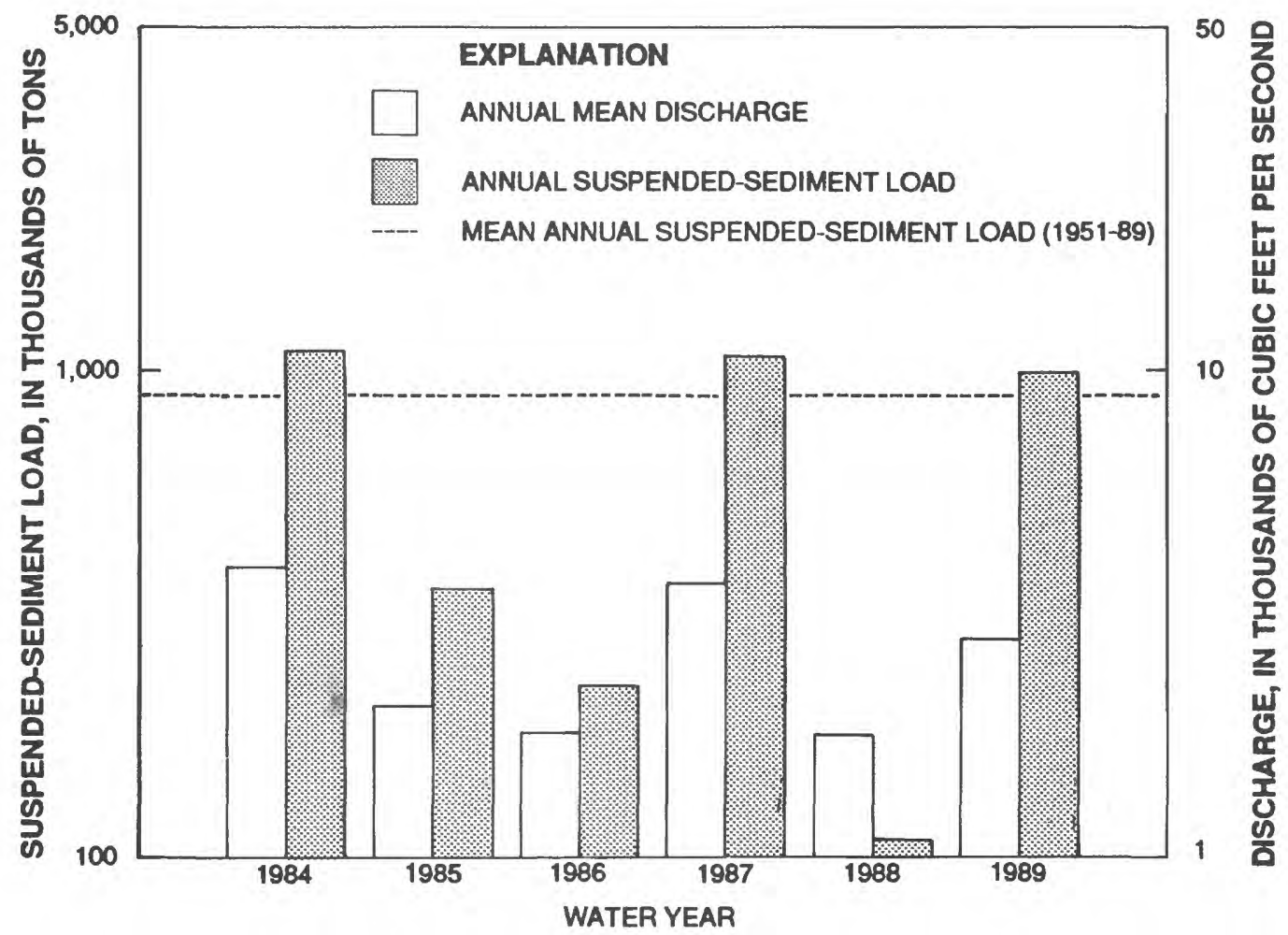

Figure 11.-Total suspended-sediment loads and mean water discharges at Yadkin River at Yadkin College, 1984-89. 


\section{WATER-RESOURCES INVESTIGATIONS}

Water-resources investigations conducted by the North Carolina District of the U.S. Geological Survey in 1988-90 included investigations to determine water use, nonpoint source pollution, water-quality characteristics of streams, effects of land use on surface- and ground-water quality, urban hydrology, estuarine-flow modeling, effects of artificial drainage from wetlands, water-quality trends, the quality of atmospheric deposition, and ground-water modeling of aquifers. This section briefly describes these investigations, summarizes progress during the period, and lists any reports produced.

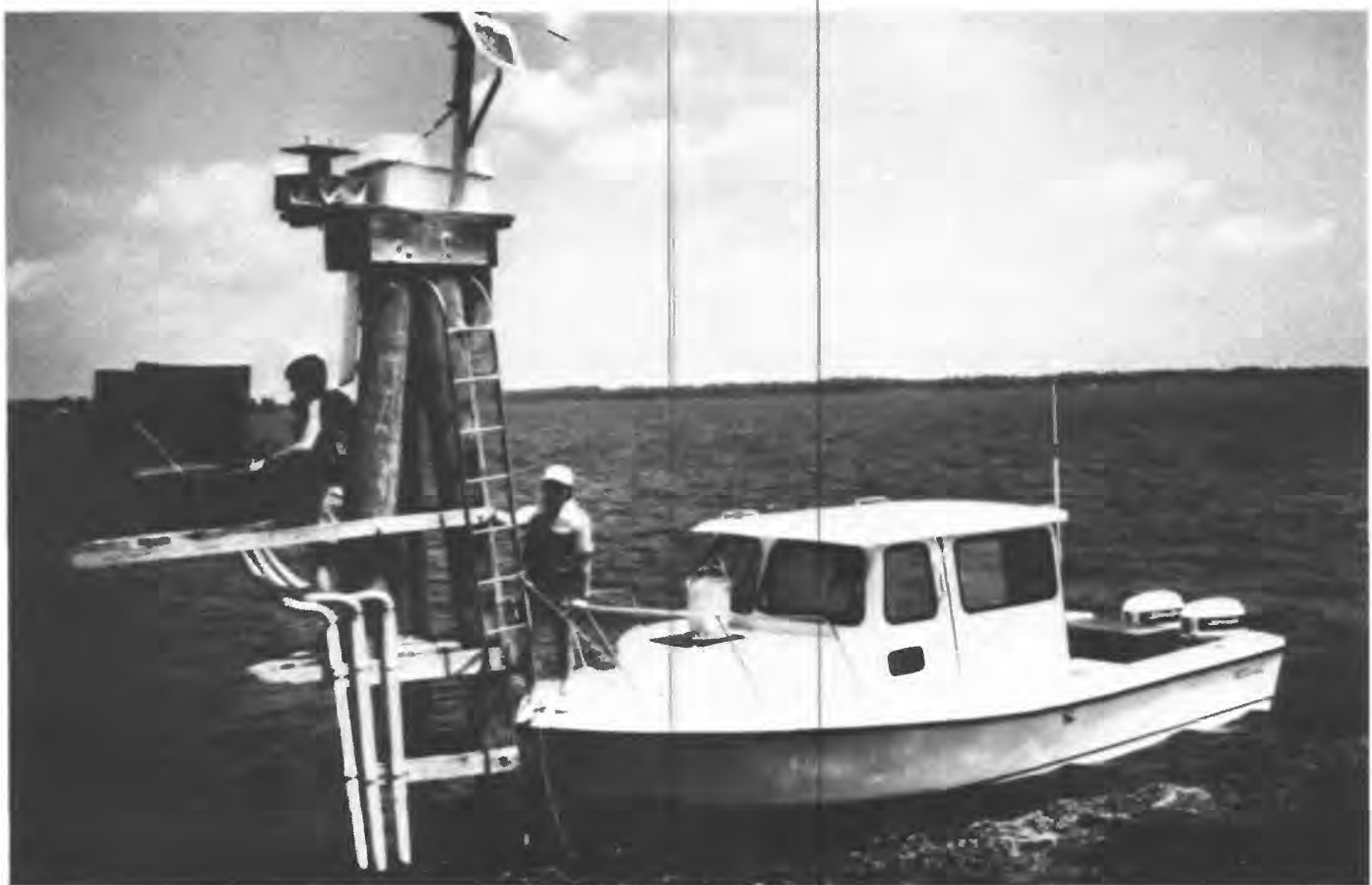

Steve Davis and Rick Treece, U.S. Geological Survey, servicing a water-quality station on the Pamlico River, North Carolina.

(Photograph by J.D. Bales, U.S. Geological Survey, Raleigh, North Carolina) 
Prolect: NC00101--Baseline water- and sediment-quality monitoring program. High Point Lake watershed, North Carolina

Location: High Point, Guilford County, North Carolina

Project Chief: M.S. Davenport

Period of Project: Water Year 1989

Cooperation: Local (City of High Point)

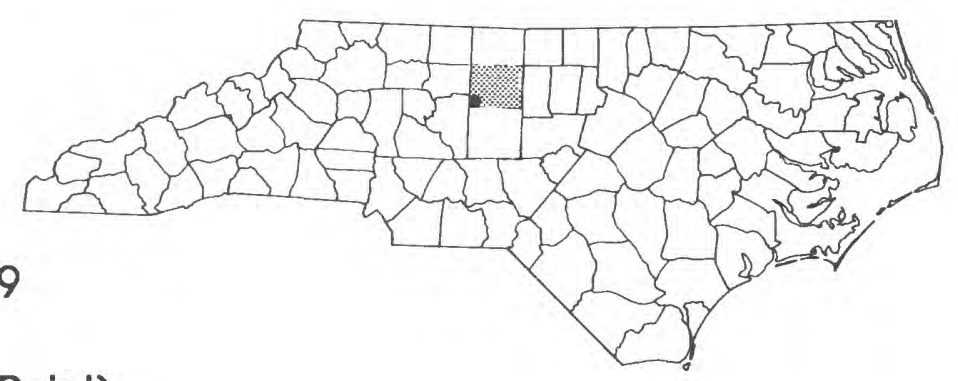

Problem: The 60-square-mile water-supply watershed that serves the city of High Point contains two forks of the Deep River, each of which contains manmade impoundments. Within the watershed are various heavy and light industrial areas, petroleum tank farms, interstate highways, pasture and row-crop areas, golf courses, and residential and urban areas.

Objectives: To (1) establish a water-quality network for continued surveillance and analysis of water-quality trends in the basin; (2) identify detectable concentrations of more than 270 physical, inorganic and organic constituents that are listed in the Safe Drinking Water Act or are known to be used in the watershed; (3) determine the concentrations and distribution of these constituents in the watershed; and (4) calculate preliminary loading estimates to the resenoir system for nutrients and suspended sediment.

Approach: Monitoring will consist of water-column and bottom-sediment sampling in Oak Hollow and High Point Lakes and their major tributary streams. Water samples will be collected at 10 stream and 8 lake sites at various sampling intervals. Analysis will include identification and quantification of physical characteristics, major dissolved constituents, nutrients, trace elements, microbiological constituents, radionuclides, and trace organic compounds, including numerous industrial compounds and pesticides. Baseand high-flow samples will be obtained at selected stream sampling sites.

Progress: Instrumentation is complete. Sample collection is in progress. 
Project: NC00301-Effects of various land-use developments on surface-water quality in the upper Neuse River basin

Location: Northeastern Piedmont of North Carolina

Project Chief: R.G. Garrett

Period of Project: $1988-90$

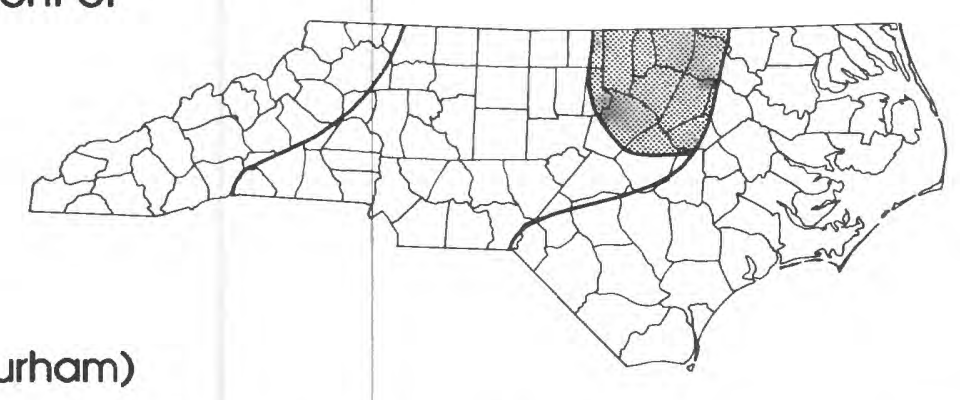

Cooperation: Local (City of Durham)

Problem: Data are needed to assess the effects of land-use development on surface-water quality in the upper Neuse River basin.

Objectives: To detect changes in water quality and to determine how those changes relate to changes in land use, such as large-scale development currently underway in the upper Neuse basin; and to estimate the effects of this development on the water quality of Lake Michie, Little Reservoir, and Falls Lake.

Approach: A network of 16 monitoring sites was established. Data are collected at specific intervals (bimonthly, yearly, floods) for organic constituents, trace metals, nutrients, major constituents, and water discharge.

Progress: Data collection began February 1988 and is currently on schedule. 
Project: NC004--Index sediment station - Yadkin River

Lecation: Piedmont region of North Carolina

Project Chief: R.G. Garrett

Period of Prolect: Continuous since 1951

Cooperation: Federal (USGS)

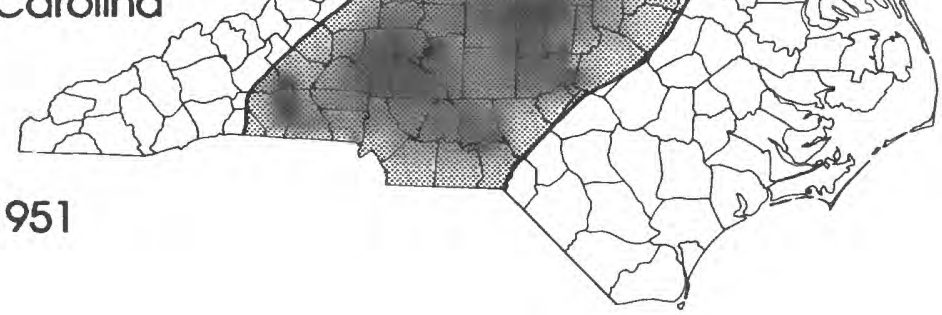

Problem: Water-resource planning and water-quality assessment require a nationwide base of standardized information. Sediment concentrations and discharges in rivers and streams must be defined and monitored.

Objectives: To provide a national bank of sediment data for use in broad Federal and State planning and action programs and to provide data for Federal management of interstate waters.

Approach: Establish and operate a nationwide network of sediment stations to provide spatial and temporal averages and trends of sediment concentration, sediment discharge, and sediment particle size transported by rivers and streams. The State index sediment station is the Yadkin River at Yadkin College (figs. 6 and 11 ).

Progress: The collection of daily sediment samples was continued through the period and additional samples were obtained during high flows. Concentrations of suspended sediment were determined for approximately 400 samples.

Report: All data collected as part of this program are published in the annual data report, "Water-Resources Data for North Carolina." 
Prolect: NCO05--Effects of atmospheric deposition on water quality of North Carolina streams

Lecation: Sandhills area of southeastern North Carolina

Project Chief: D.G. Smith

Period of Prolect: $1983-90$

Cooperation: Federal Research Program (USGS)

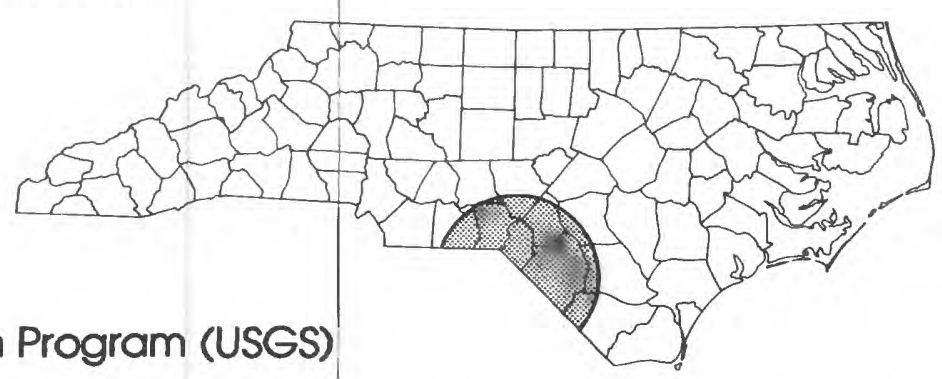

Problem: The extent and severity of atmospheric deposition in North Carolina and its effects on surface-water quality are poorly defined. Potential effects of acid inputs from this deposition include degradation of the biological communities of streams, increased rates of corrosion in watersupply systems, mobilization of trace metals, and threats to drinkingwater supplies.

Objectives: To determine (1) the extent and severity of acid deposition in North Carolina, (2) whether the sources of acid in precipitation are local or distant, and (3) the effects of acid deposition on the water quality of North Carolina streams.

Approach: Jordan Creek watershed in the Sandhills area has been selected as a site to be equipped to monitor amounts and quality of precipitation, stream discharge, stream-water quality, ground-water levels, and groundwater quality. Primarily, stream-water quality will be correlated with precipitation quality, but the influence of acid precipitation on groundwater quality will also be investigated.

Progress: Routine monitoring at one calibrated watershed site and at one atmospheric deposition site in the Sandhills continued for the fifth year of a projected 7-year effort. Several data-checking procedures were implemented, including ion-balance calculations and theoreticalconductivity calculations. Water-quality monitoring at the calibrated watershed site, Jordan Creek, has continued since 1983; additional waterquality sampling sites in the Sandhills have verified that the water quality in Jordan Creek is typical of streams in the area. Two wells have been installed-one for monitoring ground-water levels and one for monitoring ground-water quality during storms. 
Project: NC006-Flood insurance study for Mecklenburg County unincorporated areas

location: Mecklenburg County, N.C.

Project Chief: W.H. Eddins

Period of Prolect: $1989-90$

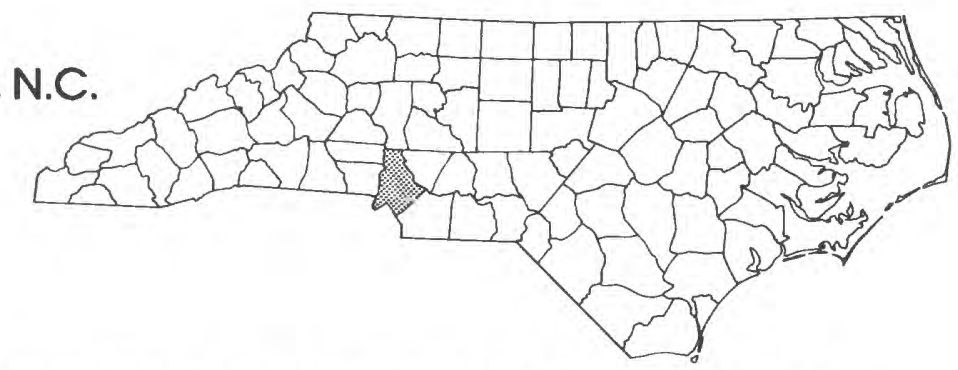

Cooperation: Federal (Federal Emergency Management Administration)

Problem: The National Flood Insurance Act of 1968 and the Flood Disaster Protection Act of 1973 provide for the operation of a flood insurance program. The Federal Emergency Management Agency (FEMA) needs flood studies in selected areas to determine applicable flood insurance premium rates. Changes need to be identified for projected impervious cover for stream basins in Mecklenburg County. Stream cross sections that were determined by photogrammetric methods in 1975-76 need to be verified with field cross sections.

Objective: To complete the flood insurance study for 123 miles of streams that drain an area greater than 1 square mile in unincorporated areas of Mecklenburg County.

Approach: The flood-plain study conducted for Mecklenburg County in 1976-78 will be updated to meet the requirements of the Federal Emergency Management Agency.

Progress: The project is nearly complete. Approximately 115 miles of streams in Mecklenburg County have been studied. Only 8 miles of streams remain to be studied. 
Project: NCOO7-Water-use data-collection program in North Carolina

Location: Statewide

Project Chief: T.P Schrader

Period of Project: Continuous since 1978

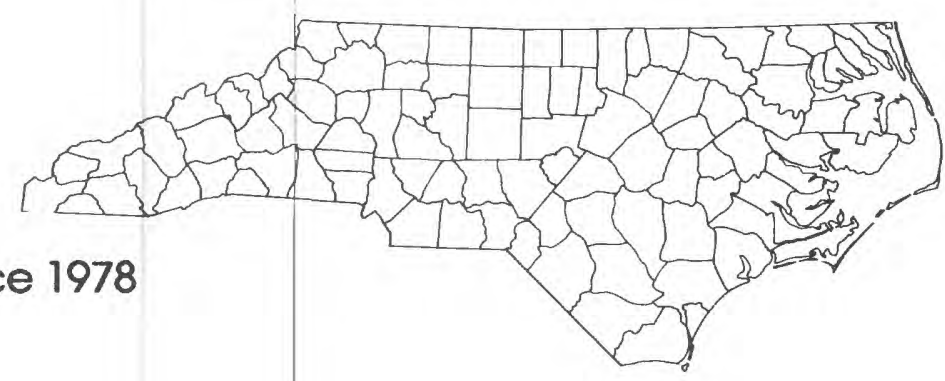

Cooperation: State (DEHNR)

Problem: There is an increasing need for better data on quantities of water being used for all purposes in North Carolina. This information is essential for long-range planning and water management.

Objective: To develop and operate a coordinated water-use data-collection, management, and reporting program that will be a water-resource planning and management tool for the State and will provide input to the national water-use data system.

Approach: Water-use information is obtained from various governmental agencies that collect water-use data and from municipalities, self-supplied industries, agricultural irrigators, and other water users. These data are stored in the State Water-Use Data System (SWUDS). Statewide estimates of water use are compiled for 12 categories of use and are published in a national water-use circular that is published every 5 years. In addition, water-use data are updated periodically, and detailed water-use surveys are conducted for special projects in certain study areas.

Progress: Results of the study pertaining to the Roanoke-Chowan subregion of North Carolina and Virginia were published in a map report. Statewide water-use data were published in "Estimated Use of Water in the United States in 1985," U.S. Geological Survey Circular 1004. This report contains water-use estimates for 12 categories of water use and includes water withdrawals, returns, and consumption. A water-use survey was conducted in nine counties in the southern Coastal Plain of North Carolina. This study focused on the collection of irrigation water-use and well information and the mapping of these data to define areas of intense pumping: A data base of public-supply wells was constructed for the Environmental Protection Agency's Municipal Wells Project II. These data were used for demonstration purposes at a workshop on hydrogeologic mapping and were stored in ARC/INFO data sets, a computer-based source of data for the USGS's waterresources studies. 


\section{Report:}

Treece, M.W., Jr., 1990, Water withdrawals in the Roanoke-Chowan subregion of North Carolina and Virginia, 1983: U.S. Geological Survey Water-Resources investigations Report 90-4007, 1 sheet.

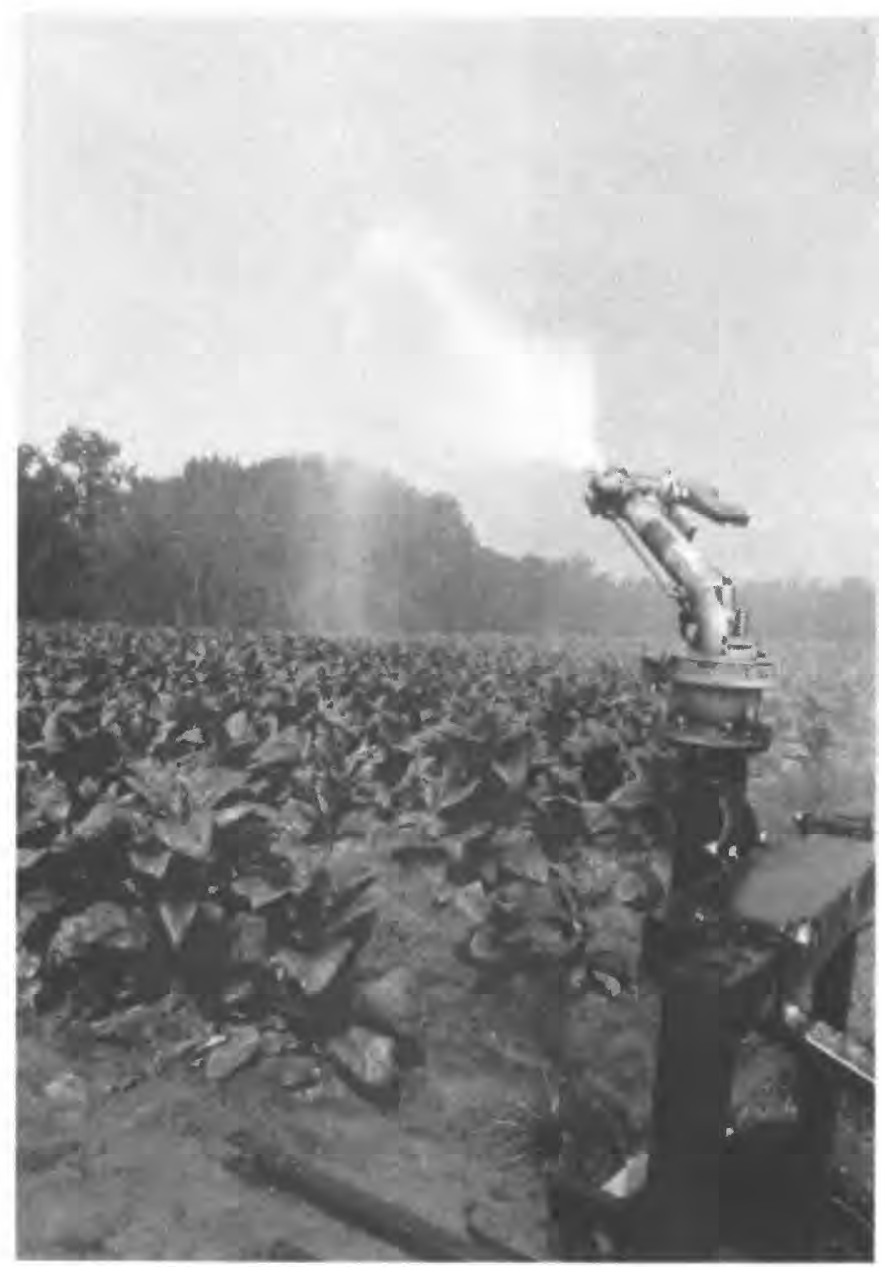

Irrigation of tobacco with traveling gun system. (Photograph by M.W. Treece, Jr., U.S. Geological Survey) 
Project: NCO10-Effects of channel relocation and proposed bridge construction on floodflows of the Catawba River near Marion, North Carolina

Location: McDowell County, North Carolina

Project Chilef: T.C. Stamey

Period of Project: $1987-88$

Cooperation: Local (McDowell County)

Problem: The relocation of a part of the Catawba River near Marion, North Carolina, and the proposed addition of a main bridge and an overflow bridge on U.S. Highway 221 have created a need for an evaluation of the effects of these physical changes on floodflow in the river.

Objectives: To determine the 100-year discharge, elevation-discharge

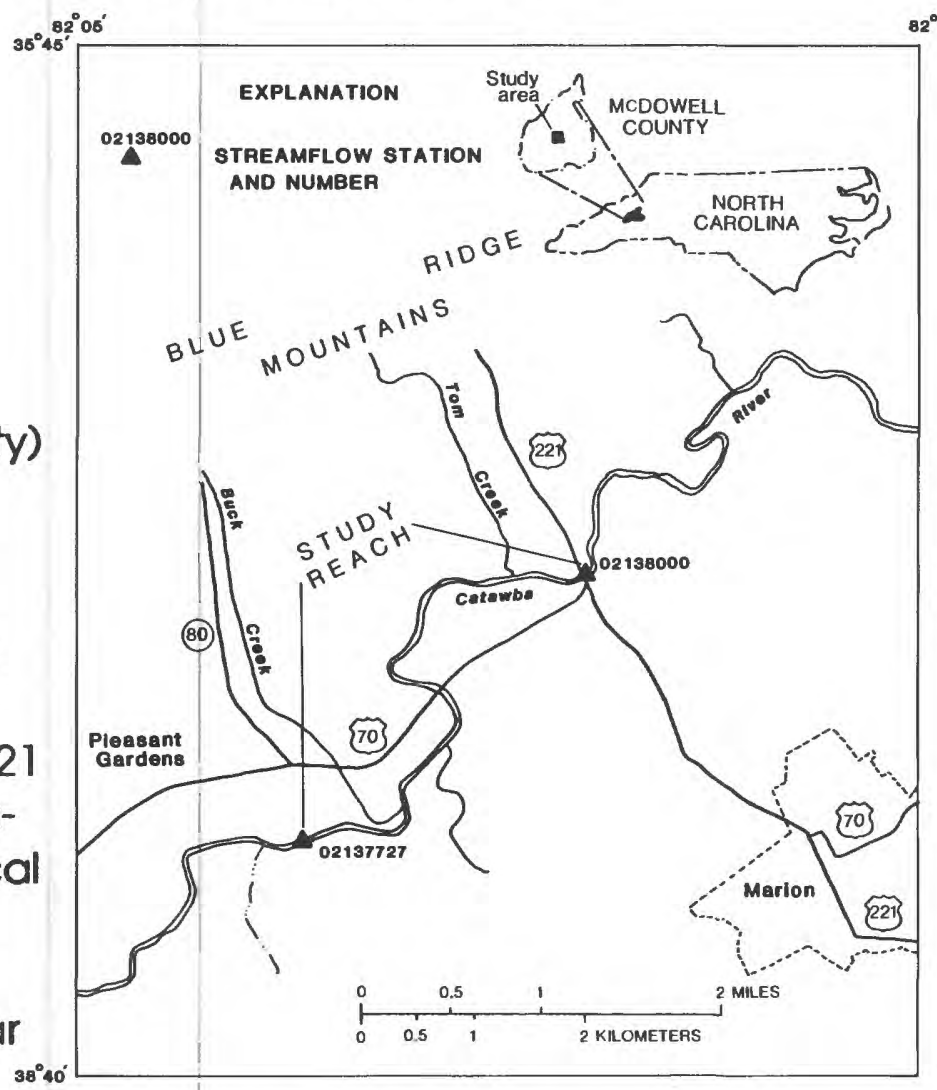
relations, flood profiles, flooding, and flooding effects for the proposed bridge conditions and channel relocation.

Approach: Land-surface elevations of the stream channel and flood-plain cross sections at 17 locations along the stream were surveyed. Streamflow data for two stations at the beginning and the end of the study reach were analyzed and used in determining flood frequencies and in the calibration of the USGS step-backwater model. This model was used to determine the 100-year flood profiles, floodways, and floodiflow effects for 1988 and for proposed bridge conditions within the study reach.

Progress: Investigation has been completed and the results have been published.

\section{Report:}

Stamey, T.C., 1989, Effects of channel relocation and proposed bridge construction on floodflows of the Catawba River near Marion, North Carolina: U.S. Geological Survey Water-Resources Investigations Report 88-4207, 16 p. 
Project: NC053--Effects of channelization on the hydrology of Chicod Creek watershed, North Carolina

Location: Pitt and Beaufort Counties, N.C.

Project Chief: R.R. Mason, Jr.

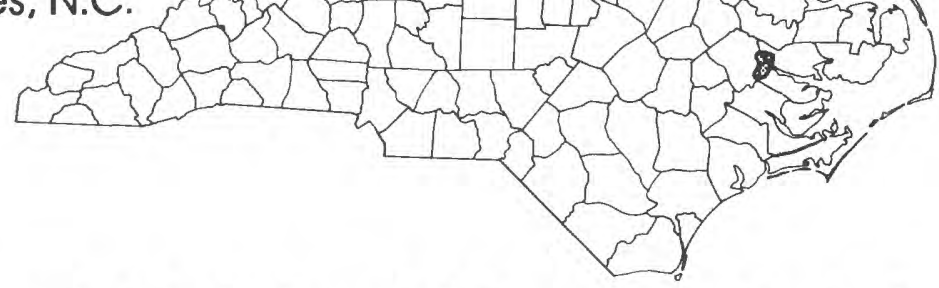

Period of Project: $1976-87$

Cooperation: Federal (U.S. Department of Agriculture, Soil Conservation Service)

Problem: The characteristics of many small stream basins in eastern North Carolina have been changed by channel improvements designed to decrease flooding and improve drainage. The effects of channelization on areal hydrology have not been studied.

Objective: To determine the effects of stream channelization on the hydrology of the Chicod Creek watershed, including streamflow, surface-water quality, and ground-water conditions.

Approach: Streamflow, water quality, and ground-water levels will be measured before, during, and after channelization activities. Streamflow and groundwater data will be analyzed by standard techniques, including correlation with nearby longer-term data-collection stations. Water-quality studies will include the occurrence and transport of conventional chemical constituents, trace metals, pesticides, and organic materials. Sediment and streambed material will be collected at two instream sediment traps to determine efficiencies and other characteristics of traps.

Progress: Collection and analysis of data have been completed and reports documenting the findings were published in 1984, 1988, and 1990.

\section{Reports:}

Watkins, S.A., and Simmons, C.E., 1984, Hydrologic conditions in the Chicod Creek basin, North Carolina, before and during channel modifications, 1975-81: U.S. Geological Survey Water-Resources Investigations Report 84-4025, $36 \mathrm{p}$.

Mason, R.R., 1988. Ground-water and surface-water conditions in the Chicod Creek basin, North Carolina, before, during, and after channel modifications, in Proceedings of the symposium on coastal water resources, Wilmington, N.C., May 22-25, 1988: Bethesda, Md., American Water Resources Association, p. 419-427. 
Mason, R.R., Jr., Simmons, C.E., and Watkins, S.A., 1990, Effects of channel modifications on the hydrology of Chicod Creek basin, North Carolina, 1975-87: U.S. Geological Survey Water-Resources Investigations Report $90-4031,83 \mathrm{p}$.

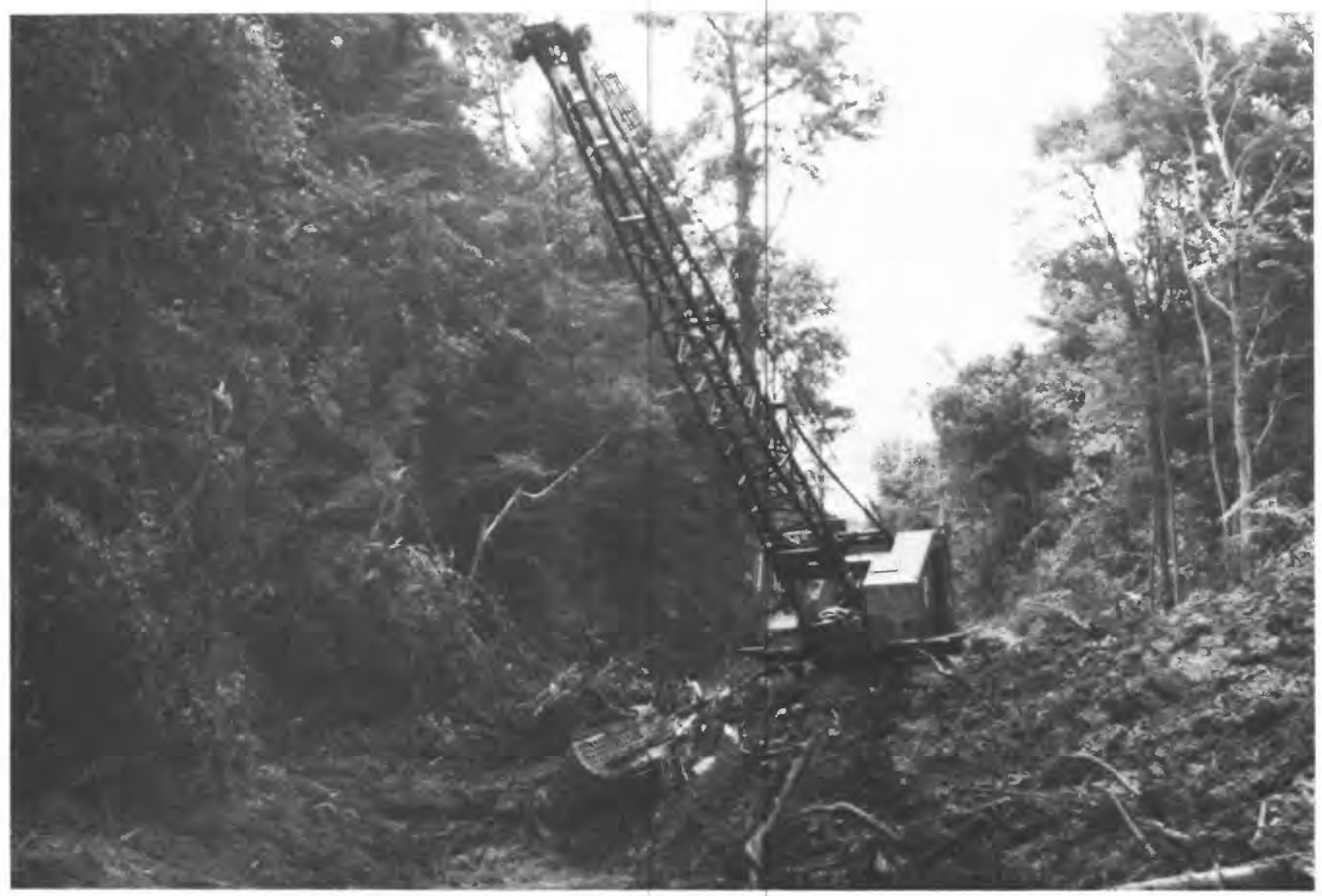

Excavation by dragline in the upstream main stem of Chicod Creek. (Photograph by Albert Coffey, U.S. Department of Agriculture, Soil Conservation Service) 
Prolect: NC071--Coastal Plain aquifer study--Regional Aquifer Systems Analysis (RASA)

Lecation: Eastern North Carolina

Project Chlef: G.L. Giese

Period of Prolect: $1979-88$

Cooperation: Federal

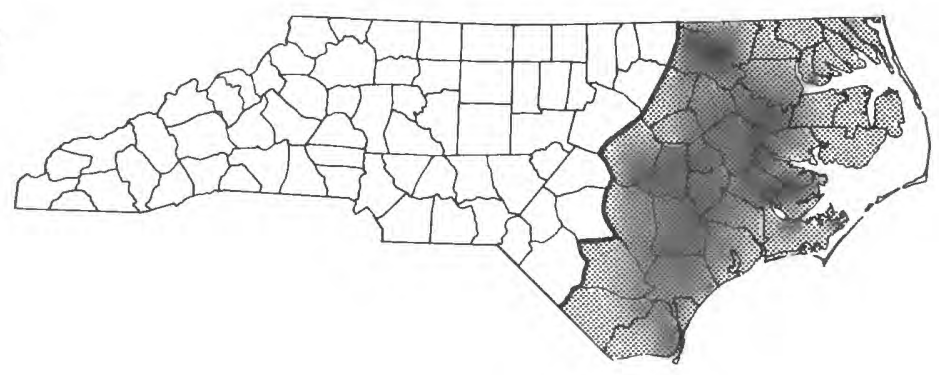

Problem: Ground water is the major source of water for every type of freshwater use in the North Carolina Coastal Plain. Withdrawal of water from several major aquifer units at rates in excess of recharge is now taking place. resulting in extensive cones of depression and the threat of saltwater intrusion into previously fresh aquifers in several areas.

Objectives: To develop the capability to make predictive evaluations of waterlevel fluctuations in the North Carolina Coastal Plain aquifers, which can best be achieved by means of a digital computer model designed to simulate the response of the multilayered aquifer system to pumping and other stresses. To accomplish this major objective, several preliminary objectives must be achieved. These are to (1) define the geology, hydrology, and geochemistry of the aquifer system; (2) define, using historical data, the ground-water flow system, natural ground-water quality, and position of freshwater-saltwater interface before extensive ground-water withdrawals began; and (3) develop a computerized data-base system to store data for use in model development.

Approach: To (1) compile and evaluate existing geologic, hydrologic, and geochemical data; (2) develop contour maps of hydrogeologic, hydrologic, and geochemical parameters and interpolate from maps values of parameters at node points in a digital-model grid system; (3) enter node values in computerized data-management system; (4) develop preliminary steady-state and transient models; and (5) collect data needed, on basis of preliminary model results, to refine models.

Progress: Investigation is complete and results have been released in three reports. 


\section{Reports:}

Coble, R.W., Giese, G.L., and Winner, M.D., Jr., 1987. Application of Regional

Aquifer System Analysis study results to ground-water management in North Carolina, in Vecchioli, John, and Johnson, A.I., eds., Regional aquifer systems of the United States, Aquifers of the Atlantic and Gulf Coastal Plain: Bethesda, Md. . American Water Resources Association, Monograph Series No. 9, p. 39-49.

Winner, M.D., Jr., and Coble, R.W., 1989. Hydrogeologic framework of the North Carolina Coastal Plain aquifer system: U.S. Geological Survey Open-File Report 87-690 (pending publication as Professional Paper 1404-I), 155 p. Giese, G.L., Eimers, J.L., and Coble, R.W., 1991, Simulation of ground-water flow in the Coastal Plain aquifer system of North Carolina: U.S. Geological Survey Open-File Report 90-372, 178 p. 
Project: NC073--Water quality of inflow to and outflow from Falls and Jordan Lakes, North Carolina

Lecation: North-central North Carolina

Project Chief: R.G. Garrett

Period of Project: $1982-87$

Cooperation: Federal (U.S. Army Corps of Engineers)

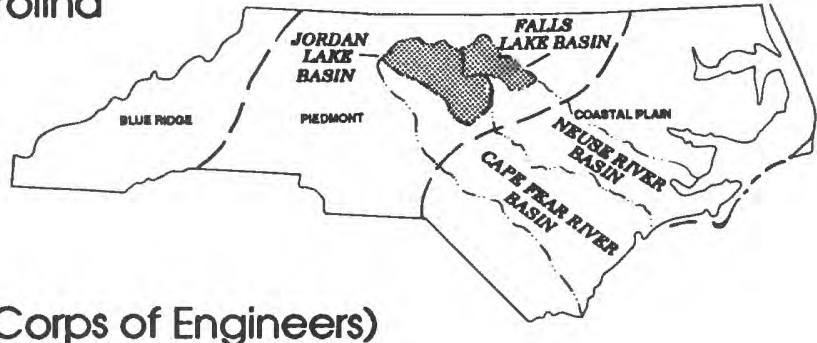

Problem: The filling of the 13,900-acre Jordan Lake was completed in February 1982. The filling of the 11,300-acre Falls Lake was completed in June 1983.

Few data are available on the quality of inflow to the lakes; however, several cities plan to use the lakes for public water supply. Chemicalquality characteristics of inflow and outflow need to be determined for current and future development of these lakes for water supply.

Objective: To collect hydrologic data for evaluating chemical-quality characteristics of inflow to and outflow from Falls and Jordan Lakes under existing conditions.

Approach: Seven sites on major streams flowing into Falls Lake and four sites on streams flowing into Jordan Lake were selected as data-collection stations, as well as one site at each outflow. Continuous stage, temperature, and specific conductance are to be collected at each site. Concentrations of major constituents, nutrients, trace metals, and suspended sediment are to be determined from approximately 12 stream samples per year. Values of alkalinity, $\mathrm{pH}$, dissolved oxygen, and specific conductance are to be determined at time of sample collection.

Progress: Water-quality data collection has been completed, and the results were published in two reports in 1990.

Reports:

Garrett, R.G., 1990, Water-quality characteristics of inflow to and outflow from B. Everett Jordan Lake, North Carolina, 1982-86: U.S. Geological Survey Water-Resources Investigations Report 90-4096, 49 p.

Garrett, R.G., 1990. Water-quality characteristics of inflow to and outflow from Falls Lake, North Carolina, 1982-87: U.S. Geological Survey Water-Resources Investigations Report 90-4097, 56 p. 
Prolect: NCO74--Effects of stream restoration on hydrology of the Grove Creek watershed and Open Marsh Water Management of salt marshes at Hobucken and West Onslow Beach, North Carolina

Lecation: Duplin, Onslow, and Pamlico Counties, North Carolina

\section{Prolect Chief: B.F. Pope}

Period of Prolect: $1982-91$

\section{Cooperation: State (DEHNR)}

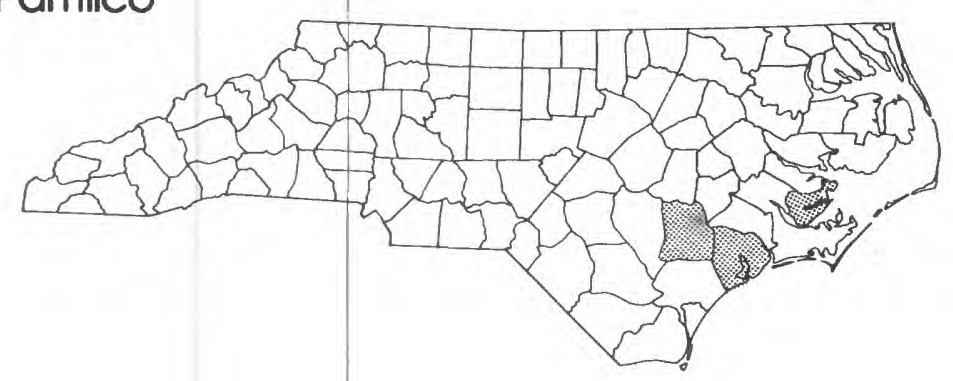

Problem: Grove Creek, in its present swampy condition, and the tidal marshes at Hobucken and West Onslow Beach are breeding grounds for mosquitos. Because a water environment is critical to mosquito development, the North Carolina Department of Environment, Health, and Natural Resources needs documentation of hydrologic changes that occur as a result of their streamrestoration techniques at Grove Creek and Open Marsh Water Management techniques to be used at Hobucken and West Onslow Beach marshes, which are designed to limit mosquito breeding areas and thus reduce mosquito populations.

Objective: To define the hydrology of Grove Creek and the tidal marshes at Hobucken and West Onslow Beach before, during, and after the different modification techniques used at each site to control mosquito breeding.

Approach: Ten data-collection sites will be established within the Grove Creek basin, including one site on Nahungo Creek, an adjacent control basin. Streamflow data will be collected at two sites on a continuous basis and at one site on a periodic basis. Continuous or periodic ground-water elevations will be collected at 25 shallow wells. Limited surface-water quality will be collected at five locations. A total of 6 recording surfacewater gages and 8 ground-water level gages will be operated at the Hobucken and West Onslow Beach sites. Periodic water-level measurements will be made in 22 wells. Entomologic data collection will be done by a private contractor to determine the effects of the hydrologic changes on mosquito populations.

Progress: Two reports have been published for the Grove Creek sites. Data are being compiled and analyzed to define hydrologic conditions at the Hobucken and West Onslow Beach sites; a final report is in preparation. 


\section{Reports:}

Stamey, T.C., 1985, Frequency and duration of flooding of Grove Creek near Kenansville, North Carolina, for present and proposed restored channel conditions: U.S. Geological Survey Water-Resources Investigations Report 85-4298, $52 \mathrm{p}$.

Stamey, T.C., 1989, Sediment transport and accretion and the hydrologic environment of Grove Creek near Kenansville, North Carolina: U.S. Geological Survey Water-Resources Investigations Report 89-4086, 30 p.

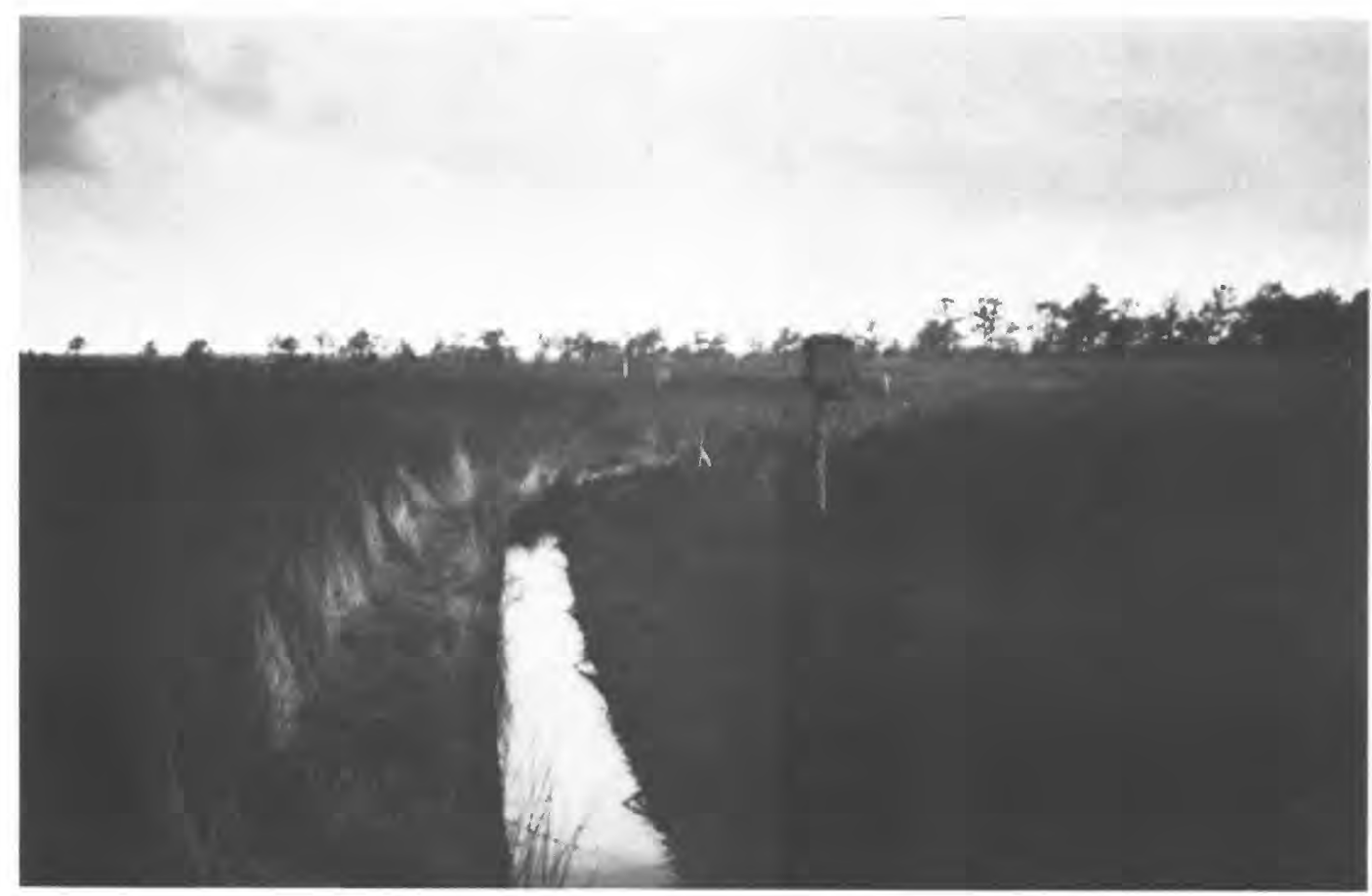

Observation well near Open Marsh Water Management ditch at salt marsh near Hobucken, North Carolina.

(Photograph by B.F. Pope, U.S. Geological Survey, Raleigh, North Carolina) 
Project: NCO75--Central Coastal Plain aquifer study

Location: East-central North Carolina

Project Chief: W.L. Lyke

Period of Project: $1983-88$

Cooperation: State (DEHNR) and local

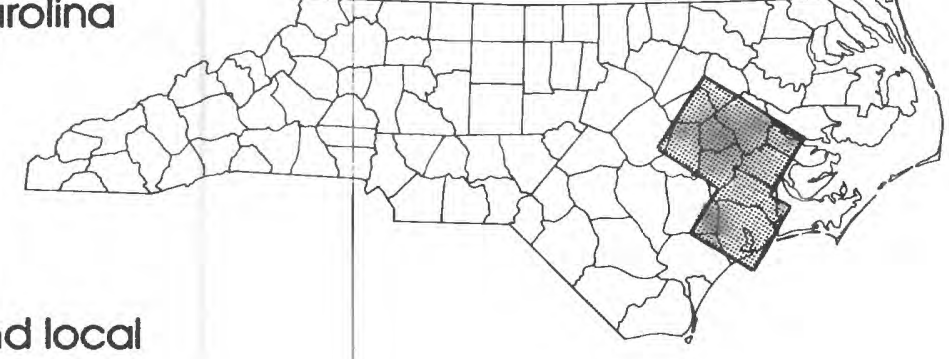

Problem: Increasingly heavy ground-water use by municipalities and industries since World War II has stressed the Cretaceous aquifer system of the central Coastal Plain, producing water-level declines of several feet per year. As a result of these declines, 14 local agencies and the North Carolina Department of Environment, Health, and Natural Resources joined with the USGS to conduct a study of the water-supply potential in this area.

Objectives: To (1) evaluate the ground-water supply potential of the central Coastal Plain and (2) make quantitative predictive evaluations of the effects of alternative ground-water development schemes, especially with regard to maximum development potential and declines in water levels.

Approach: To (1) develop a hydrogeologic framework for the study area; (2) incorporate the framework into a digital computer model of the ground-water flow system; (3) simulate, using the model, the response of the flow system to pumping stresses and evaluate the ground-water supply potential of the central Coastal Plain study area; and (4) perform some test-well drilling and observation-well construction.

Progress: The investigation is complete and results have been published in 11 reports.

\section{Reports:}

Lyke, W.L., and Winner, M.D., Jr., 1986, Altitude of basement surface in the central Coastal Plain area of North Carolina: U.S. Geological Survey Water-Resources Investigations Report 86-4082, 2 sheets.

Winner, M.D., Jr., and Lyke, W.L., 1986, History of ground-water pumpage and water-level decline in the Black Creek and upper Cape Fear aquifers of the central Coastal Plain of North Carolina: U.S. Geological Survey WaterResources Investigations Report 86-4168, $21 \mathrm{p}$. 
Brockman, A.R., Lyke, W.L., and Winner, M.D., Jr., 1989, Potentiometric surface of the Peedee aquifer in the central Coastal Plain of North Carolina. December 1986: U.S. Geological Survey Water-Resources Investigations Report 87-4236, 1 sheet.

Lyke, W.L., Winner, M.D., Jr., and Brockman, A.R., 1989, Potentiometric surface of the Black Creek aquifer in the central Coastal Plain of North Carolina, December 1986: U.S. Geological Survey Water-Resources Investigations Report 87-4233, 1 sheet.

Winner, M.D., Jr., and Lyke, W.L., 1989, Aquifers in Cretaceous rocks of the central Coastal Plain of North Carolina: U.S. Geological Survey WaterResources Investigations Report 87-4178, $71 \mathrm{p}$.

Winner, M.D., Jr., Lyke, W.L., and Brockman, A.R., 1989, Potentiometric surface of the lower Cape Fear aquifer in the central Coastal Plain of North Carolina, December 1986: U.S. Geological Survey Water-Resources Investigations Report 87-4234, 1 sheet.

Winner, M.D., Jr., Lyke. W.L., and Brockman, A.R., 1989, Potentiometric surface of the upper Cape Fear aquifer in the central Coastal Plain of North Carolina, December 1986: U.S. Geological Survey Water-Resources Investigations Report 87-4235, 1 sheet.

Eimers, J.L., Lyke, W.L., and Brockman, A.R., 1990, Simulation of ground-water flow in aquifers in Cretaceous rocks in the central Coastal Plain. North Carolina: U.S. Geological Survey Water-Resources Investigations Report 89-4153, $101 \mathrm{p}$.

Lyke, W.L., 1990, Ground-water study of the central Coastal Plain, North Carolina: U.S. Geological Survey Open-File Report 90-192, Water Fact Sheet. Lyke, W.L., and Brockman, A.R., 1990, Ground-water pumpage and water-level declines in the Peedee and Black Creek aquifers in Onslow and Jones Counties, North Carolina, 1900-86: U.S. Geological Survey Water-Resources Investigations Report 89-4197, 32 p.

Lyke, W.L., and Winner, M.D., Jr., 1990, Hydrogeology of aquifers in Cretaceous and younger rocks in the vicinity of Onlsow and southern Jones Counties, North Carolina: U.S. Geological Survey Water-Resources Investigations Report 89-4128, $49 \mathrm{p}$. 
Prolect: NC081--Effects of land-management practices on sediment and chemical transport in Guilford County, North Carolina

Lecation: Guilford County, North Carolina

Project Chief: D.A. Harned

Period of Project: $1984-91$

Cooperation: Local (Guilford County Soil and Water Conservation District)

Problem: Extensive farming in the Piedmont Province of the southeastern States results in agricultural runoff, one of the major nonpoint sources of pollution from agricultural lands. Agricultural runoff is a known contributor of sediments, nutrients, and toxic substances to water resources, yet its full effect is unknown.

Objectives: To (1) evaluate and quantify fluvial sediment and associated chemical constituents transported via surface water from basins chosen according to land-management practices; and (2) define changes in quantities of sediment and selected nutrients and organics following implementation of Best Management Practices (BMP's) in a mixed land-use basin.

Approach: Four small basins are being studied. One is forested and will remain that way for the duration of the project to characterize background conditions. Two are totally agricultural, one using BMP's and the other using standard land-management practices. Existing hydrologic and chemical characteristics will be compared over a 4- to 5-year period. The fourth basin has mixed-rural land uses. It will be characterized during the initial 3-year period and then BMP's will be implemented for a 2- to 3-year followup period.

Progress: Chemical-quality samples continue to be collected from surface water at the background and mixed-rural land-use basins, and from surface water, unsaturated and saturated zone water, precipitations, and soil at the two agricultural basins. Discharge data is collected at all four basins and ground-water levels are monitored at the two agricultural basins. BMP's are being implemented at the mixed-rural land-use basin. 


\section{Reports:}

Hill, C.L., 1986, Monitoring the effects of land-management practices on sediment and chemical transport in northeastern Guilford County. North Carolina (abs.), in Proceedings of the fourth annual meeting of the Weed Science Society of North Carolina: Raleigh, N.C., p. 62-63.

Hill, C.L., 1987. Monitoring the effects of land-management practices on water quality in Guilford County, North Carolina, in Proceedings of the American Water Resources Association symposium. May 1987: American Water Resources Association, p. 137-147.

Hill, C.L., 1989, Hydrologic and chemical-quality data from four rural basins in Guilford County, North Carolina, 1985-88: U.S. Geological Survey Open-File Report 89-578, $105 \mathrm{p}$.

Hill, C.L., 1989, The effects of land-management practices on surface- and groundwater quality in rural northeastern Guilford County, North Carolina (abs.), in U.S. Geological Survey second national symposium on water quality: Abstracts of the technical sessions, Orlando, Florida, November 12-17, 1989: U.S. Geological Survey Open-File Report 89-409, p. 38.

Hill, C.L., 1991, Effects of land-management practices on sediment yields in northeastern Guilford County, North Carolina: U.S. Geological Survey Water-Resources Investigations Report 90-4127, 40 p. 
Project: NC082--Evaluation of the hydrogeology in the Cincinnati arch region with regard to isolation of nuclear wastes in buried crystalline rocks

Location: Eastern Indiana, north-central Kentucky, and western Ohio

Project Chief: O.B. Lloyd, Jr.

Period of Prolect: $1984-88$

Cooperation: Federal (USGS)

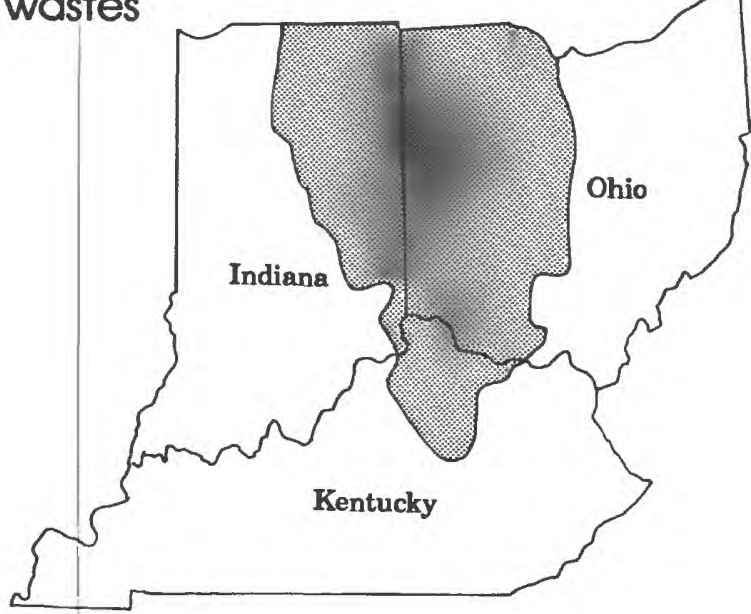

Problem: There is a need for a permanent repository for high-level radioactive wastes that will (1) isolate the wastes from an accessible environment for a long period of time and protect the wastes from human intrusion, and (2) minimize migration of wastes and be an environment in which transport is predictable in both time and space.

Objectives: To summarize the hydrology of the Paleozoic sediments in the Cincinnati arch area and determine (1) if suitable hydrogeologic characteristics exist for isolation of high-level radioactive waste in buried crystalline rocks that may underlie the area, and (2) if sufficient data are available to define areas where the buried crystalline-rock concept might be applied in any subsequent site-screening program.

Approach: Existing data will be compiled and reviewed. Appropriate maps and cross sections will be prepared to define the hydrogeologic conditions.

Progress: Investigation has been completed and results have been published. Data were collected and analyzed to determine (1) the depth to, thickness, extent, water-transmitting capacity, hydraulic head, and ground-water quality of the Mount Simon Sandstone (the formation that lies directly on the crystalline basement rock) and (2) the thickness, extent, continuity, and water-transmitting capacity of confining beds that occur between the top of the Mount Simon Sandstone and the bottom of the Knox Dolomite.

\section{Report:}

Lloyd, O.B., Jr., and Davis, R.W., 1989, Preliminary hydrogeologic evaluation of the Cincinnati arch region for underground high-level radioactive waste disposal, Indiana, Kentucky, and Ohio: U.S. Geological Survey WaterResources Investigations Report 88-4098, 42 p. 
Prolect: NC083--Ground-water supply and potential for contamination, Cherry Point Marine Corps Air Station, North Carolina

Lecation: Craven County, North Carolina

Project Chief: J.L. Eimers

Period of Project: 1986-92

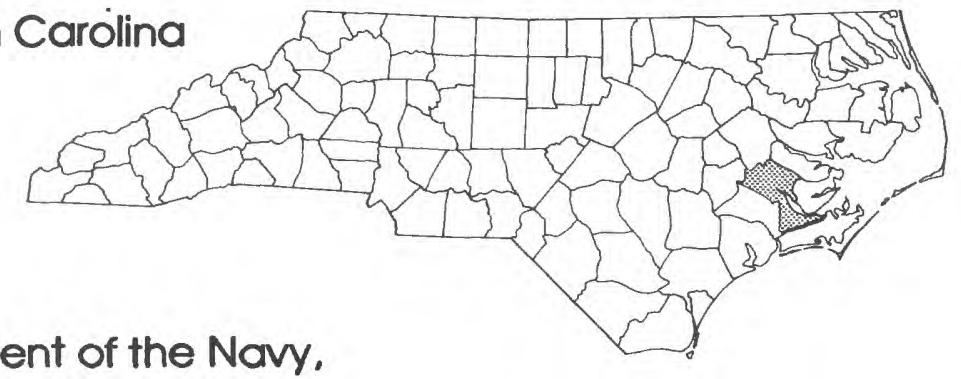

Coeperation: Federal (Department of the Navy, U.S. Marine Corps)

Problem: Since the Cherry Point Marine Corps Air Station opened in 1942, water supply for the Air Station has been derived from the confined Castle Hayne aquifer. Hazardous and toxic liquid wastes have been spilled or disposed of at numerous landfill sites for more than $\mathbf{4 0}$ years. The heaviest concentration of disposed wastes and spills is very near the line of production wells that supply most of the water for the Air Station. In some places the potentiometric surface in the Castle Hayne aquifer is below the water table, thereby creating the potential for downward movement of contaminants from the water table into the Castle Hayne aquifer. Potential contamination of the water-supply aquifer is also recognized through the possibility of direct connection between the aquifers from improper well construction, incomplete plugging, or corroded or breached casing.

Objectives: To evaluate (1) the quality of ground water being pumped from the Air Station wells that tap the Castle Hayne aquifer, (2) the potential for contamination of the water-supply aquifer by hazardous and toxic wastes that occur at various surface disposal sites at the Air Station and by salinewater encroachment, and (3) alternative ground-water use and management practices that will help reduce the chances for contamination of the watersupply aquifer.

Approach: Water samples will be collected from all supply wells and other selected wells that tap the Castle Hayne aquifer. Chemical analyses will include priority pollutants and other constituents associated with work at the Air Station. Test wells will be drilled into the Castle Hayne aquifer, an intermediate aquifer, and the water-table aquifer. Water samples will be collected from test wells and analyzed. Geophysical logs will be made of all wells. Potentiometric surface maps and a hydrogeologic framework will be 
developed. Aquifer tests will be made to determine hydraulic properties. The potential for contamination will be evaluated based on water-quality. hydrologic, and hydrogeologic data. The development of a digital model is planned for use in optimization studies of management practices.

Progress: Hydrogeologic and ground-water quality investigations near the wastewater treatment plant and polishing lagoon have been completed; continuous water-level recorders were installed on 8 of 12 wells open to the surficial and intermediate aquifers in May and June 1987. Four reports have been prepared.

\section{Reponts:}

Lloyd, O.B., Jr., and Daniel, C.C., III, 1988, Distribution, source, and significance of selected organic compounds in water from the Castle Hayne aquifer. Cherry Point, North Carolina, in Proceedings of the symposium on coastal water resources, Wilmington, North Carolina, May 22-25, 1988: Bethesda, Maryland, American Water Resources Association, p. 519-530.

Lloyd, O.B., Jr., and Daniel, C.C., III, 1988, Hydrogeologic setting, water levels, and quality of water from supply wells at the U.S. Marine Corps Air Station. Cherry Point, North Carolina: U.S. Geological Survey Water-Resources Investigations Report 88-4034, 76 p.

Murray, L.C., and Daniel, C.C., III, 1990, Hydrogeologic and water-quality data from well clusters near the wastewater-treatment plant, U.S. Marine Corps Air Station, Cherry Point, North Carolina: U.S. Geological Survey Open-File Report 89-615, $56 \mathrm{p}$.

Murray, L.C., and Keoughan, K.M., 1990, Hydrogeologic data, water levels, and quality of water from monitoring wells installed at the U.S. Marine Corps Air Station, Cherry Point, North Carolina: U.S. Geological Survey WaterResources Investigations Report 89-4200, 86 p. 
Prolect: NC084--An appraisal of the ground-water resources of Camp Lejeune Marine Corps Base, North Carolina

Location: Onslow County, North Carolina

Project Chief: A.P. Cardinell

Period of Project: 1986-92

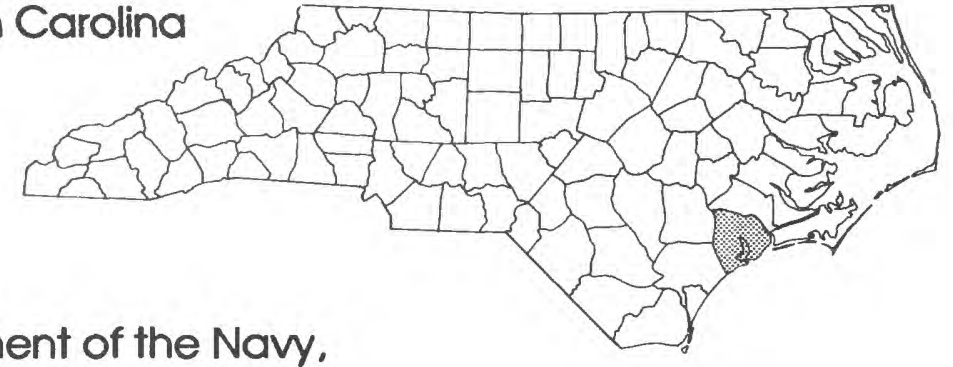

Cooperation: Federal (Department of the Navy. U.S. Marine Corps)

Problem: Since Camp Lejeune Marine Corps Base was established in the late 1930 's, more than 100 water-supply wells have been drilled and placed in operation to satisfy increasing demands for water at the Base. Ground-water withdrawals from these wells rate among the largest in the State and supplied 6.9 million gallons per day to the Base population of about 68,000 in 1988 . The amount of waste generated by Base operations has also increased. There is concern that increased ground-water needs will also increase the threat of contamination of existing wells by disposed wastes and saline water. Evaluation of the hydrogeology of the Base, determination of ground-water use, and assessment of management practices are needed to reduce the chances of contamination and to help assure that future water-supply needs are met.

Objectives: To define the ground-water resources of the Base and to construct a ground-water flow model that can be used to evaluate alternative ground-water use and management practices to aid in reducing chances for further contamination and assuring that future water-supply needs are met.

Approgch: The study has been divided into three phases: Phase 1 will examine available hydrologic, hydrogeologic, and water-use data; Phase 2 will collect additional data needed to complete data gaps and construct observation wells; and Phase 3 will develop a ground-water flow model that can be used for optimization studies of management practices.

Progress: Preliminary geologic sections were made from existing well-log data. To fill data gaps, additional test wells were drilled to depths up to 250 feet at various locations on the Base, and a seismic-reflection profiling survey on the New River was completed. Digital water-level recorders were established at 14 wells on the Base, and digital recorders were placed on one tidal gage, a rain gage, and one streamflow gage. Construction of a fine- 
grid, finite-difference ground-water flow model is planned for the last phase of the study.

\section{Reports:}

Harned, D.A., Lloyd, O.B., Jr., and Treece, M.W., Jr., 1989. Assessment of hydrologic and hydrogeologic data at Camp Lejeune Marine Corps Base, North Carolina: U.S. Geological Survey Water-Resources Investigations Report 89-4096, $64 \mathrm{p}$.

Cardinell, A.P., Harned, D.A., and Berg, S.A., 1990, Continuous seismic-reflection profiling of hydrogeologic features beneath New River, Camp Lejeune, North Carolina: U.S. Geological Survey Water-Resources Investigations Report 89-4195, $33 \mathrm{p}$.

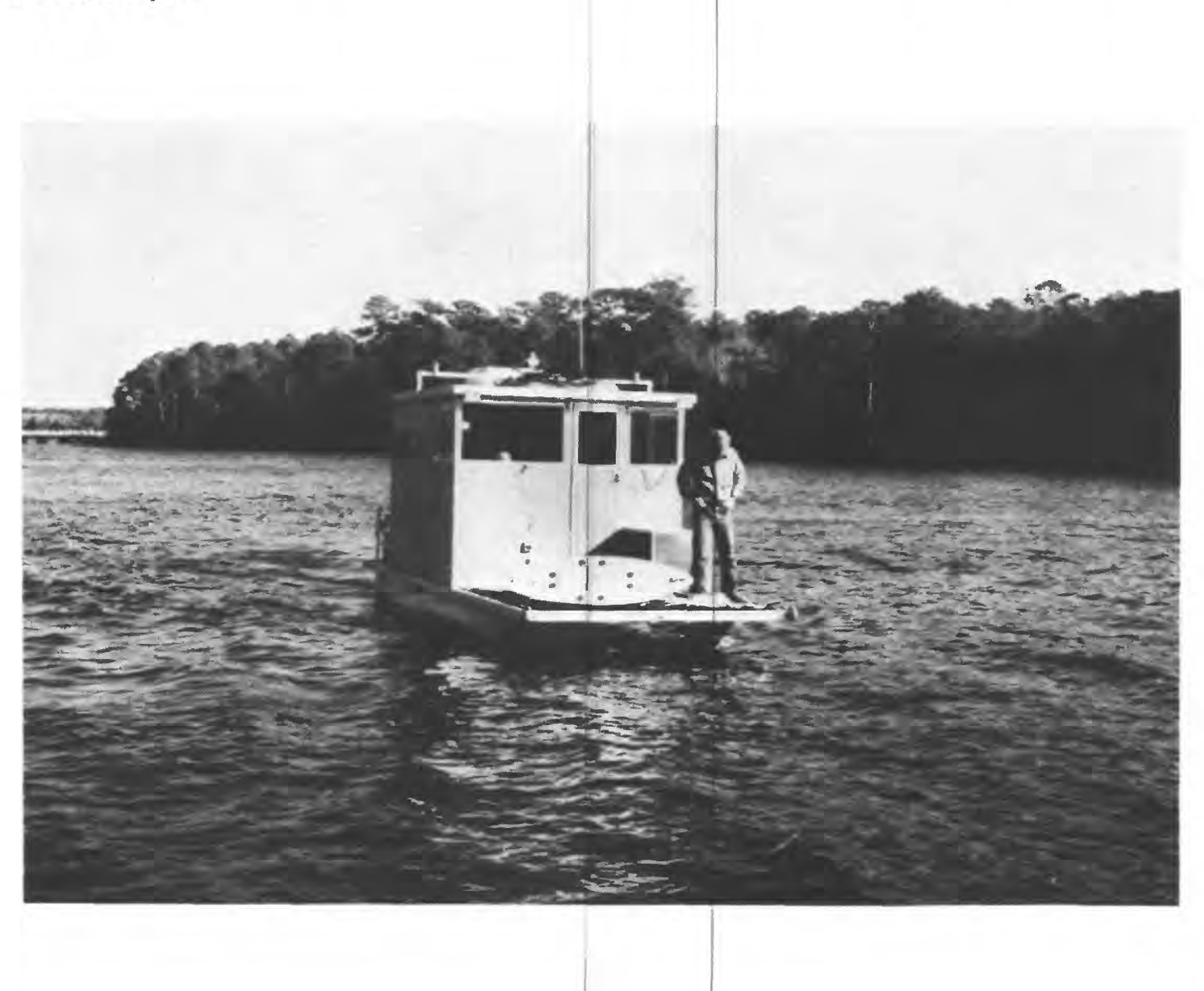

John West, U.S. Geological Survey, Geologic Division, standing on the boat next to profiling equipment used in the seismic-reflection profiling survey of the New River estuary at Camp Lejeune. North Carolina.

(Photograph by D.A. Harned, U.S. Geological Survey, Raleigh, North Carolina) 
Project: NC085-A reconnaissance evaluation of surface-water, drinking-water, and effluent-water quality in the Greensboro, North Carolina, area

Lecation: Greensboro, Guilford County, North Carolina

Project Chief: M.S. Davenport

Period of Project: $1986-87$

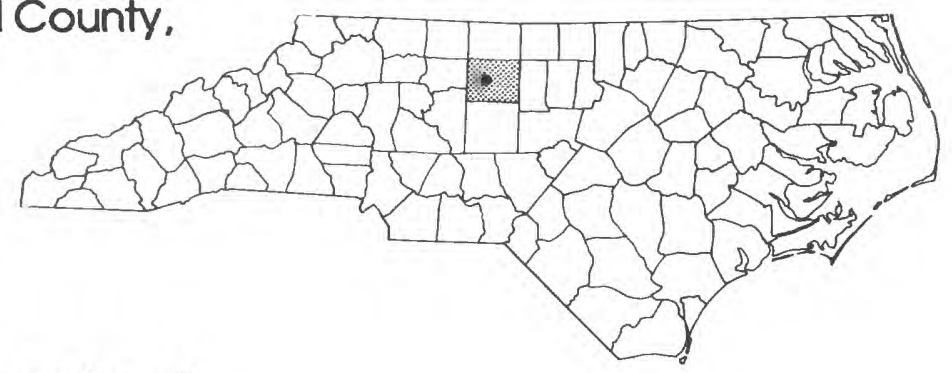

Cooperation: Local (City of Greensboro)

Problem: As the largest municipality in the Haw River basin upstream from Jordan Lake, the City of Greensboro is concerned about the quality of surface waters in the city's water-supply watershed and downstream in the Haw River basin.

Objectives: To (1) define quality of water in the Greensboro area with particular emphasis on trace elements, nutrients, and synthetic organic compounds:

(2) define quality of water in the city's raw water-supply reservoirs and outflow from two wastewater treatment plants; (3) compare quality of water draining urban, suburban, and rural watersheds; and (4) determine loadings of nutrients and trace elements.

Approach: Water-quality and stream data were collected at 19 sampling sites, compiled, and analyzed based on sampling-site location, land use, State and Federal water-quality standards and criteria, and loadings.

Progress: Investigation has been completed and results were published in 1988 and 1989.

\section{Reports:}

Davenport, M.S., 1988, Surface-water and water-quality data from selected streams and treated waters in the Greensboro area, North Carolina, 1986-87: U.S. Geological Survey Open-File Report 88-169, 462 p.

Davenport, M.S., 1989. Water quality in Reedy Fork and Buffalo Creek basins in the Greensboro area, North Carolina, 1986-87: U.S. Geological Survey Water-Resources Investigations Report 88-4210, 81 p. 
Project: NC086-Low-flow characteristics of North Carolina streams

location: Statewide

Project Chief: G.L. Giese

Period of Project: $1986-89$

Cooperation: Federal (USGS)

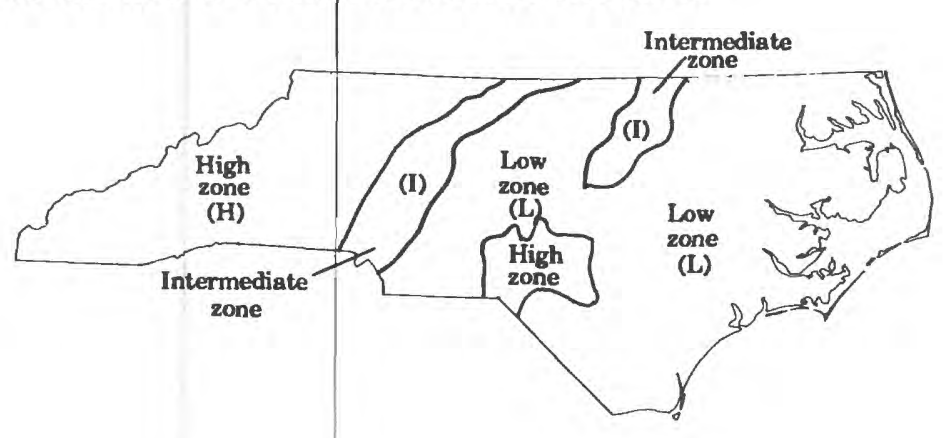

Problem: Since the early 1950's, the USGS has been the recognized source for low-flow frequency estimates for streams in North Carolina. Recent implementation of a new State policy to deny or severely restrict waste-discharge permits for streams with zero flows and the 7 consecutive-day 10-year minimum average flow level (minimum 7Q10 flow) makes it important to develop more accurate estimates for low-flow frequency characteristics, particularly for small streams where minimum $7 Q 10$ flows are likely to be zero and where little or no streamflow data are available.

Objective: To develop reliable methods for estimating low-flow frequency characteristics of North Carolina streams for use at sites where few or no discharge measurements are available.

Approach: Approximately 900 sites will be selected for which low-flow characteristics have been determined for natural conditions on the basis of actual discharge measurements. These sites will be used in conjunction with geologic, topographic, and climatological maps to establish regions of similar low-flow characteristics. Equations or other tools will be developed to estimate low-flow statistics for each region.

Progress: Ten low-flow hydrologic zones covering the entire State were identified. Regression equations and/or statistical summaries for estimating low-flow statistics were provided for each hydrologic zone.

Report: Final report describing the study has received Director's approval for publication. Camera-ready copy is in progress. 
Project: NC087--Water-quality characteristics of selected streams in forested areas of North Carolina

Location: Statewide

Project Chief: W.S. Caldwell

Period of Project: $1986-89$

Cooperation: State (DEHNR)

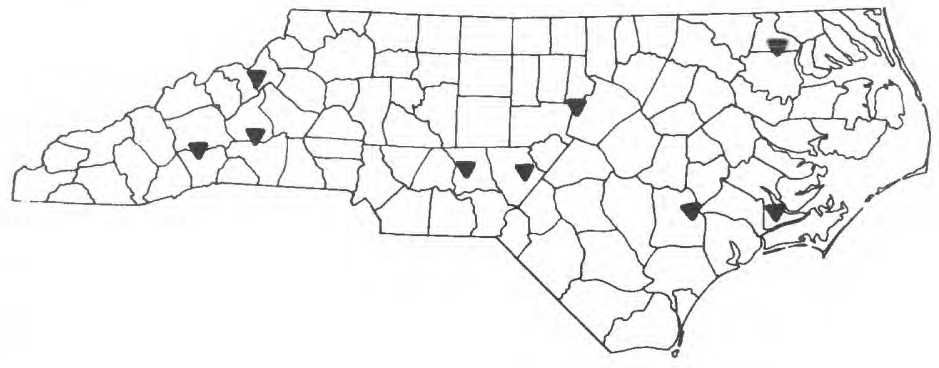

Problem: A substantial data base does not exist for defining background or natural levels of nutrients, most toxic chemicals, and priority pollutants for North Carolina streams. In many instances, changes in various constituent levels, caused by man-induced activities, cannot be accurately quantified until levels contributed by background sources are determined.

Objectives: To adequately assess the background constituent level of streams in forested areas of the State will require (1) quantifying selected physical and chemical characteristics of streamflow draining undeveloped forested basins; (2) identifying and quantifying selected biological constituents, fish communities, and benthic macroinvertibrates in selected streams; and (3) determining relations of chemical characteristics of streamflow to precipitation chemistry, basin soils, basin geology, and aquatic biology.

Approach: Physical, chemical, and biological data will be collected from nine streams draining undeveloped, forested basins across the State. The basins range in size from 0.67 to 7.53 square miles. Samples will be collected to define characteristics during a full range of flow and seasonal conditions.

Progress: The collection of data was completed in September 1988, and interpretation of results has begun. The physical and chemical data are being used to (1) compare constituent levels from each geochemical zone, and (2) facilitate development of regional or area-wide estimates of background constituent levels. The biological data are being used to characterize the biological organisms present in the individual streams during the time of sampling. 
Project: NCO90--National ground-water atlas (Segment 10)

Location: Illinois, Indiana, Kentucky,

Ohio, and Tennessee

Project Chief: O.B. Lloyd, Jr.

Period of Prolect: $1987-89$

Cooperation: Federal (USGS)

Problem: A unified summary of ground-water conditions in the Nation is needed.

A national ground-water atlas will summarize in one publication and at common scales the ground-water information the Survey has collected and published over the years.

Qbjectives: To (1) provide a summary of the ground-water resources in the study area for an audience that includes the lay public, consultants, planners, colleges and universities, congressional staffs and other governmental agencies, and (2) synthesize ground-water information that now exists at many scales into a single document that can be used to respond to requests for information from the above groups and others.

Approach: Existing ground-water data, including that generated by the Regional Aquifer Systems Analysis (RASA) program, will be compiled and evaluated. Pertinent data and illustrations will be assembled to define hydrologic conditions for all important aquifers in the study area, and the text will be prepared to describe the information for the intended audience.

Progress: Pertinent reports and illustrations have been obtained and important aquifers have been identified. Illustrations are being prepared to describe the hydrologic and water-quality characteristics, and the thickness and extent of these aquifers.

Report: The report has been completed and has been submitted for approval for publication. 
Prolect: NC091--Estuarine water quality and the management of artificial drainage from wetlands

Lecation: Beaufort and Hyde Counties, North Carolina

Project Chief: M.W. Treece, Jr.

Period of Project: $1987-92$

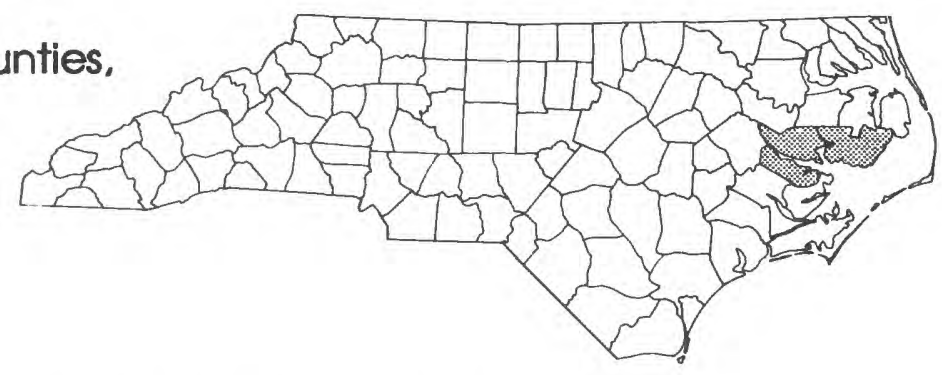

Coeperation: State (DEHNR/Albemarle-Pamlico Estuarine Study)

Problem: The Albemarle-Pamlico peninsula contains one of the largest continuous areas of wetlands in the Nation. Land surfaces on the peninsula and on adjoining areas are typically only a few feet above sea level and, under natural conditions, much of the land is swampy. Consequently, much of these wetlands are artificially drained to permit agricultural use. Two issues related to artificial-drainage activities on the peninsula have not been adequately addressed: (1) downstream effects of artificial-drainage management activities (water-control structures) are unknown, and (2) the effects of intermittent freshwater drainage on aquatic nursery area salinity regimes are not well understood.

Objectives: To (1) quantify the effects of tidegates and flashboard risers on runoff rates and volumes, and on sediment and nutrient loads in drainage ditches immediately downstream from agricultural fields; (2) determine the effects of variable and changing freshwater flows on the salinity in a particular nursery area in Pamlico Sound; and (3) qualitatively assess the cumulative effects of artificial drainage activities on downstream aquatic nursery areas.

Approach: Two sets of sites will be established; each set of sites will consist of (1) a site that has water-control structures in place, and (2) two sites that have no water-control structures but, after two years of data collection, will have water-control structures installed. Two years of data collection will follow installation of the control structures. Discharge from the sites will be monitored; nutrient and sediment concentrations will be measured bi-weekly and during five high-flow events per year. Conductivity meters and a tide gage will be placed in nursery area receiving waters to continuously monitor conductivity and water level. 
Progress: Field data-collection sites have been established. Three flashboard riser sites are in Beaufort County and three tidegate sites are in Hyde County. All sites have been instrumented with stage recorders, velocity meters. and automatic water-quality samplers. Raingages have been installed near the Beaufort County sites and near the Hyde County sites. A tide gage has been installed in the Campbell Creek nursery area; conductivity meters will be in place by July 1989. Water-quality data collection has begun and manual discharge measurements are underway. Extensive efforts at coordination with State and local officials and with other researchers have been made. Two reports have been published.

\section{Reports:}

Bales, J.D., 1988, Fractional step method for two-dimensional estuarine transport, in Abt, S.R., and Gessler, Johannes, eds., Hydraulic engineering, Proceedings of the 1988 national conference: New York, American Society of Civil Engineers, p. 1182-1187.

Bales, J.D., 1989, Land drainage and estuarine salinity response, in Ports, M.A., ed. Hydraulic engineering. Proceedings of the 1989 national conference on hydraulic engineering: New York, American Society of Civil Engineers, p. 200-205.

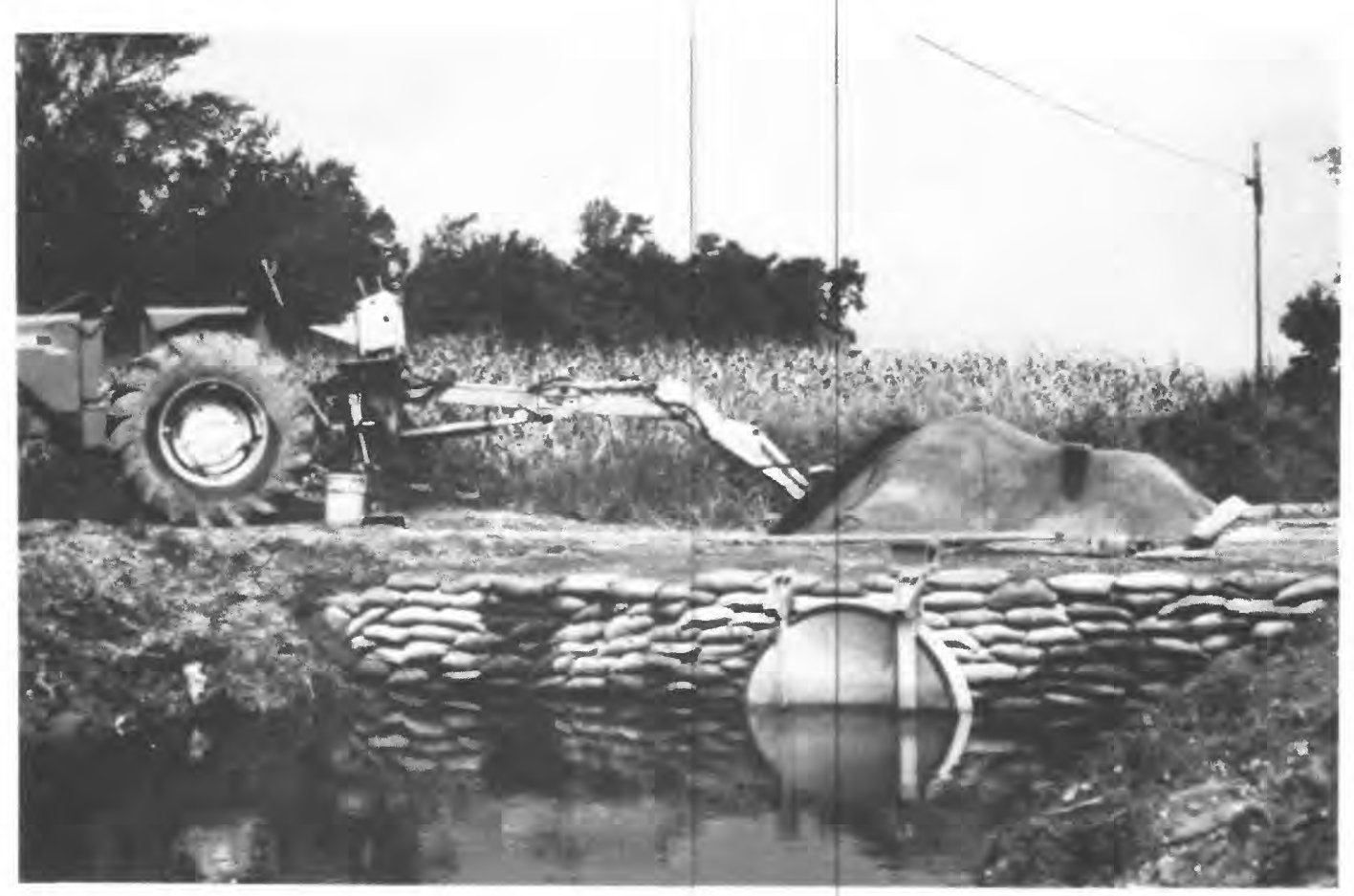

Installation of a tide gate in Hyde County, North Carolina. (Photograph by J.D. Bales, U.S. Geological Survey, Raleigh, North Carolina) 
Project: NC092--Determination of flows and flow patterns in the Pamlico River and Neuse River estuaries

Location: Pamlico River and Neuse River estuaries, North Carolina

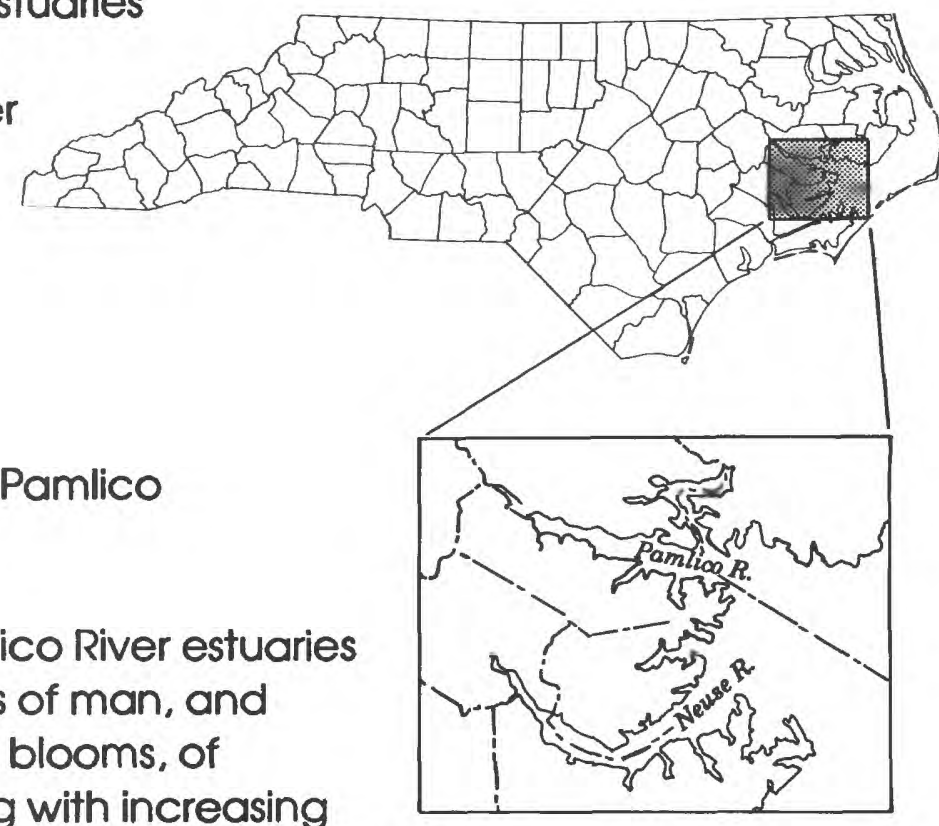

Project Chief: J.D. Bales

Period of Project: $1987-92$

Coeperation: State (DEHNR/Albemarle-Pamlico Estuarine Study)

Problem: The Neuse River and the Pamlico River estuaries are heavily affected by the activities of man, and symptoms, such as fish kills and algal blooms, of water-quality problems are occurring with increasing frequency. Yet, there is not now a data-collection network designed to provide continuous-flow information for either of the estuaries, nor is there any documentation of the flow patterns that is required to properly implement existing management programs.

Objectives: To (1) collect and analyze information needed to obtain a record of flow and flow patterns in the Pamlico River and Neuse River estuaries, and (2) provide a calibrated and validated hydrodynamic model of the two systems.

Approach: The study will include (1) long-term confinuous data collection (tidal data, conductivity, and meteorological information), (2) short-term intensive velocity measurements within the systems, and (3) numerical model calibration, validations, and application. Following validation of the numerical model, flows and flow patterns will be determined in the Neuse and Pamlico River estuaries from the continuous records of stage, conductivity, meteorological conditions, and tributary inflows.

Progress: Five tide gages and two conductivity meters have been installed in the Pamlico River. Six tide gages and two conductivity meters have been installed in the Neuse River. The North Carolina Geodetic Survey has placed benchmarks near each tide gage. Water-quality meters for continuously monitoring conductivity, temperature, and dissolved oxygen have been placed on 11 aids-to-navigation in the two rivers. Bathymetric data for the entire Albemarle-Pamlico system were received from the National Ocean Survey. A 
computer program for generating a numerical grid from bathymetric data has been obtained and is being applied. Preliminary work with the hydrodynamic model has begun.

\section{Reports:}

Bales, J.D., 1987, Review of concepts and data relevant to hydrodynamic and water-quality modeling of the Albemarle-Pamlico Sound. North Carolina, in Duffy, M.A., ed., Proceedings of the workshop on hydrodynamic and waterquality models for the Albemarle-Pamlico estuarine study: Raleigh, North Carolina Department of Natural Resources and Community Development. Report No. 87-03, p. 13-28.

Bales, J.D. 1989. Flows and flow patterns in the Pamlico and Neuse River estuaries, in Holman. R.E., ed. . Project abstracts for period 1989-1990. Albemarle-Pamlico estuarine study: Raleigh, North Carolina Department of Environment, Health, and Natural Resources, Project no. 89/08, September 1989, p. 8.

Bales, J.D., 1989, Off-site effects of water-control structures, in Holman, R.E., ed., Project abstracts for period 1989-1990. Albemarle-Pamlico estuarine study: Raleigh, North Carolina Department of Environment, Health, and Natural Resources, Project no. 89/08, September 1989, p. 9.

Bales, J.D., 1990, Data-collection program for Pamlico River estuary model calibration and validation, in Spaulding, M.L., ed., Estuarine and coastal modeling. Proceedings of the conference, Newport, R.I., November 15-17, 1989: New York, American Society of Civil Engineers, p. 492-501.

Bales, J.D., 1990 Hydrodynamics and circulation of the Pamlico River and Neuse River estuaries (abs.), in North Carolina Department of Environment. Health. and Natural Resources, Project abstracts - FY 89 and FY 90: Raleigh, North Carolina Department of Environment, Health, and natural Resources. Project no. 90-18, p. 26.

Treece, M.W., and Bales, J.D., 1990, Hydrologic and water-quality effects of artificial-drainage control (abs.), in North Carolina Department of Environment, Health, and Natural Resources, Project abstracts - FY89 and FY90: Raleigh, North Carolina Department of Environment, Health, and Natural Resources, Project no. 90-18, p. 27. 
Prolect: NC093--Hydrologic characteristics and water-quality trends of the Albemarle-Pamlico estuarine system, North Carolina

location: Northern Coastal Plain and northeastern Piedmont, North Carolina

Project Chiet: D.A. Harned

Period of Project: 1987-89

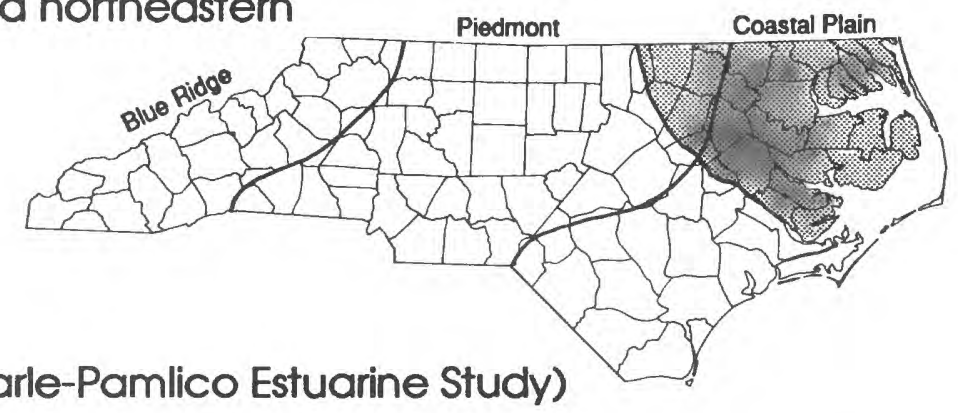

Cooperation: State (DEHNR/Albemarle-Pamlico Estuarine Study)

Problem: Existing information on the Albemarle-Pamlico estuarine system needs to be compiled and evaluated for temporal and spatial trends relating to water quality in the system.

Objectives: To identify, compile, and analyze existing hydrologic, water-quality, and related data from the Albemarle and Pamlico Sounds drainage basin.

Approach: Existing information, such as land-use data, agricultural statistics and fertilizer-use data, forest data, and data on road length, atmospheric precipitation quality, population, manufacturing employment, streamflow, point sources, and estuary water quality will be entered into a Statistical Analysis System (SAS) data set. These data will be analyzed using parametric and nonparametric techniques to determine temporal and spatial trends in water quality and to identify correlations.

Progress: A bibliography was compiled and published. The water-quality and basin characteristics data sets have been constructed and edited. Data analysis has been completed and the final report has been published. Four films documenting this estuary study were planned, shot, and edited for the Coastal Celebration Fair, April 8, 1989.

\section{Reports:}

Bales, J.D., and Nelson, T.M., 1988, Bibliography of hydrologic and water-quality investigations conducted in or near the Albemarle-Pamlico Sounds region, North Carolina: U.S. Geological Survey Open-File Report 88-480, 148 p.

Harned, D.A., and Davenport, M.S., 1990, Water-quality trends and basin activities and characteristics for the Albemarle-Pamlico estuarine system, North Carolina and Virginia: U.S. Geological Survey Open-File Report 90-398, $164 \mathrm{p}$. 
Project: NC094-Development of ecological surveys for the National Water-Quality Assessment (NAWQA) program

Location: Nationwide

Project Chief: M.E. Gurtz

Period of Project: $1987-92$

Cooperation: Federal (USGS)

Problem: The NAWQA program is an ongoing program of data acquisition, interpretation, and assessment of the Nation's water resources. Biological aspects being considered

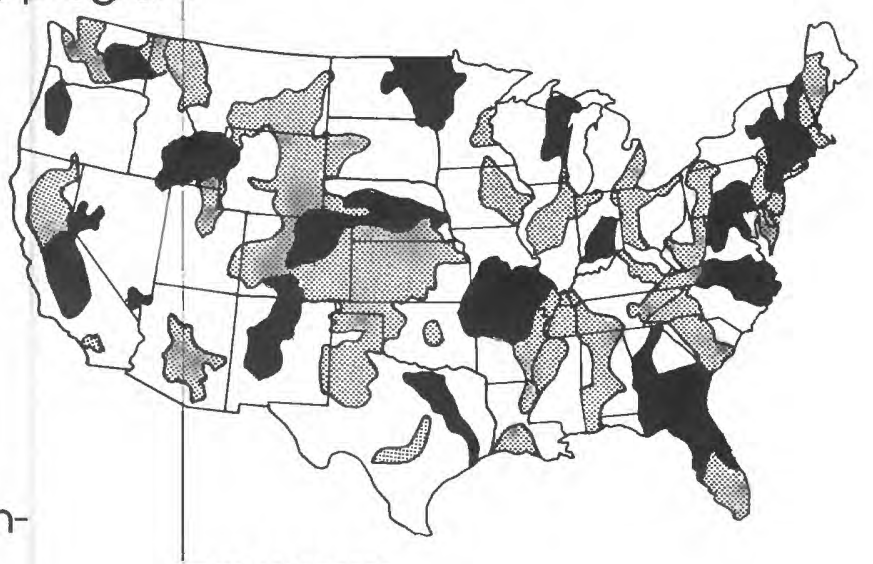
EXPLANATION

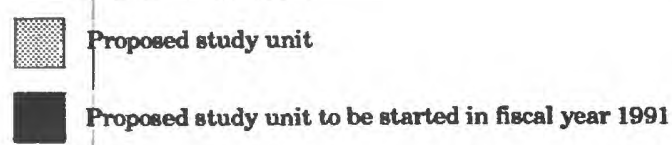
for this program include bioassays, tissue analysis, and ecological surveys. An ecological survey will provide an assessment of the current status of aquatic biological communities in the basin, establish a baseline for trends in biological communities, aid interpretation of physical and chemical aspects of water quality as well as other biological measures, and lead to improved understanding of the functioning of river systems.

Objectives: To develop protocols for conducting ecological surveys in NAWQA.

Approach: Development of procedures for conducting an ecological survey in NAWQA will be conducted in two phases: Phase I will include a literature search and will involve consultations with scientists within and without the USGS on concepts on ecological surveys; Phase II will include a field test of methods and revision of recommended procedures.

Progress: Progress toward development of ecological surveys has included consultations with USGS scientists (project chiefs of the NAWQA surfacewater pilot-study units, researchers from the National Research Program and the Biology Task Group, and others), plus discussions with researchers from universities and State agencies, the U.S. Fish and Wildlife Service, and the U.S. Environmental Protection Agency. An extensive literature review has been conducted, and field tests have begun in two pilot studies: the Yakima River in Washington and the upper Illinois River in Illinois, Indiana, and Wisconsin. 


\section{Report:}

Gurtz, M.E., 1989, Ecological aspects of the National Water-Quality Assessment program, in Pederson, G.L., and Smith, M.M., compilers, U.S. Geological Survey second national symposium on water quality: Abstracts of the technical sessions, Orlando, Florida, November 12-17, 1989: U.S. Geological Survey Open-File Report 89-409, p. 33-34.

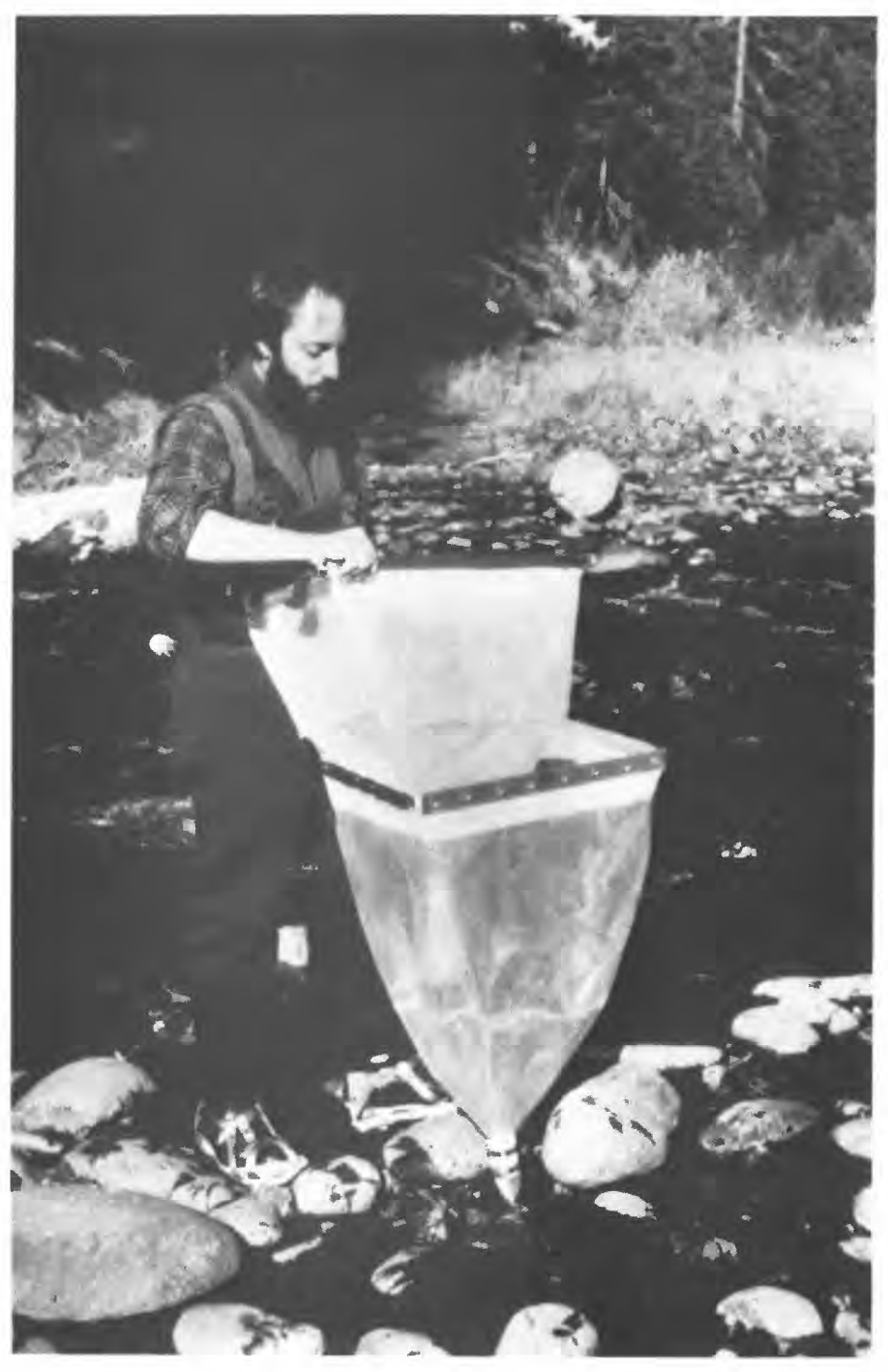

Steve Fend, U.S. Geological Survey National Research Program, using a kick net to collect benthic macroinvertebrate samples in Rattlesnake Creek, Washington.

(Photograph by M.E. Gurtz, U.S. Geological Survey, Raleigh, North Carolina) 
Project: NC097--Urban stormwater hydrology in North Carolina

Location: Statewide

Prolect Chief: R.R. Mason

Period of Prolect: 1988-94

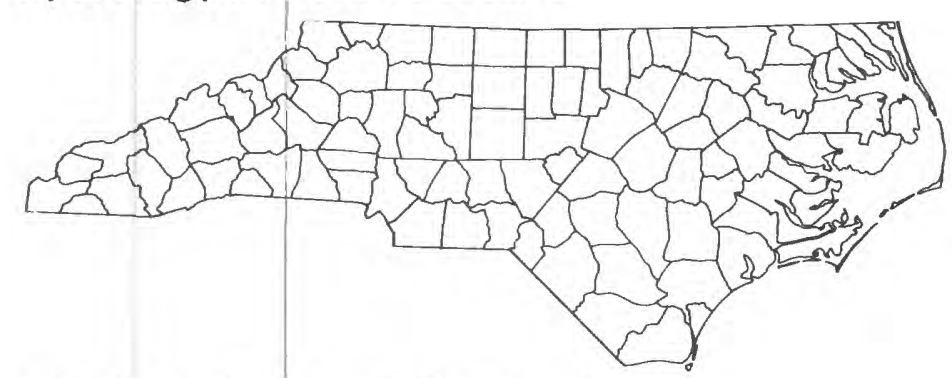

Cooperation: State and local (N.C. Dept. of Transportation and the Cities of Asheville, Chapel Hill, Fayetteville, and Raleigh)

Problem: Present methods for estimating peak stream discharge were developed using data from topographic, geologic, and climatic conditions in many parts of North Carolina. Application of these techniques to urban streams can produce questionable and, perhaps, biased results. In addition, effective design, management, and regulation of urban stormwater systems requires accurate, inexpensive methods of estimating storm runoff volumes and of formulating and routing flood hydrographs. Such methods have not been developed or tested for either rural or urban areas in North Carolina.

Objectives: To (1) develop new methods for estimating peak discharges of urban streams that will be applicable throughout North Carolina and (2) develop simple urban hydrograph formulation techniques. A secondary objective is the development of a data base for regionalization of urban rainfall-runoff model parameters.

Approach: Objectives will be met through individual rainfall-runoff studies conducted in cooperation with several North Carolina cities, such as Raleigh, Asheville, Chapel Hill, and Fayetteville. These individual projects include collection of concurrent rainfall and runoff data at a number of urban basins in each city. Most include calibration and verification of urban runoff models, simulation of long-term flood histories, and flood-frequency analyses. A large data base resulting from ongoing and proposed data collection and computer model studies combined with data available from previous urban studies in the Piedmont and Coastal Plain will be subjected to a statewide regionalization study. The regionalization study will include elements to develop regionally applicable hydrographs. The flood-frequency study will follow methods of Sauer and others (1983), whereas the unit hydrograph analysis will follow the approach outlined by Inman (1986). 
Progress: Collection of rainfall-runoff data is complete in Asheville and Raleigh and continues in Fayetteville. Schematics for computer models have been calibrated for the Asheville and Raleigh sites. As a result of a major flood that occurred in Fayetteville on September 15, 1989, the USGS, in cooperation with the city, undertook a new study to document the extent and severity of that flood. As a result, members of the project staff were temporarily reassigned to the new project and elements of the Urban Stormwater Hydrology Project were delayed. The Fayetteville flood documentation study has been completed and a report is in preparation. 
Prolect: NC098--Analysis of estuarine water quality using continuousmonitoring data

Lecation: Albemarle and Pamlico Sounds and their tributaries

Prolect Chief: R.G. Garrett

Period of Prolect: 1988-continuous

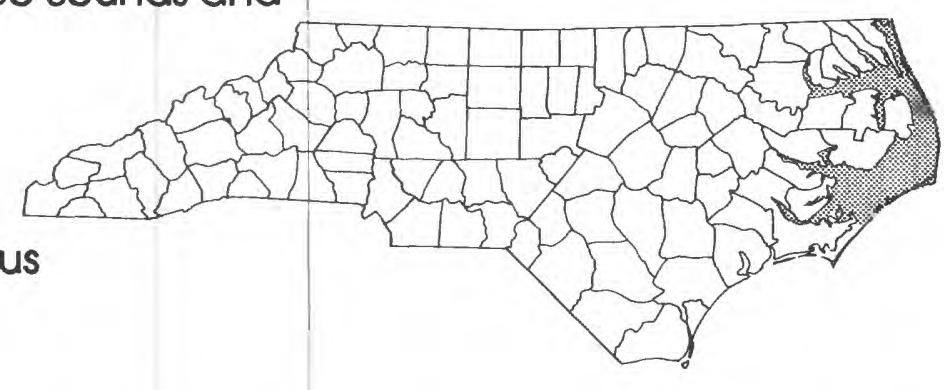

Cooperation: State (DEHNR)

Problem: Indications of environmental stress in the Albemarle-Pamlico (A-P) estuarine system are increasing; these indicators of stress appear to be directly related to A-P water quality. In order to characterize water-quality conditions in the A-P waters and to gain some understanding of the dynamics of the estuarine water-quality processes, a continuous record of important water-quality constituents is needed at a number of locations in the A-P estuarine system. Information on dissolved oxygen, temperature, and specific conductance is needed for predicting the onset of critical water-quality conditions, for defining baseline water-quality conditions, and for assessing the effects of management activities on water quality.

Objectives: To (1) collect water-quality data for a number of years and (2) provide data analysis needed to determine baseline water-quality conditions to provide insight into the dynamics of the water-quality processes and to evaluate the effects of management actions.

Approach: Water quality will be continuously monitored at 29 sites. Data from these sites will be integrated with continuously-monitored information from other sites. Dissolved oxygen and specific conductance will be recorded at 15-minute intervals for three vertical locations in the water column at each site; temperature will be monitored at one depth. Spatial and temporal variations in water quality will be evaluated.

Progress: Data collection began in April 1989. Instrumentation was completed in July 1989. 
Project: NC09801-Flow and salinity characteristics of West Neck Creek, Virginia Beach, Virginia

Location: West Neck Creek, Virginia Beach, Virginia

Project Chief: J.D. Bales

Period of Project: $1990-1992$

Cooperation: State (DEHNR)

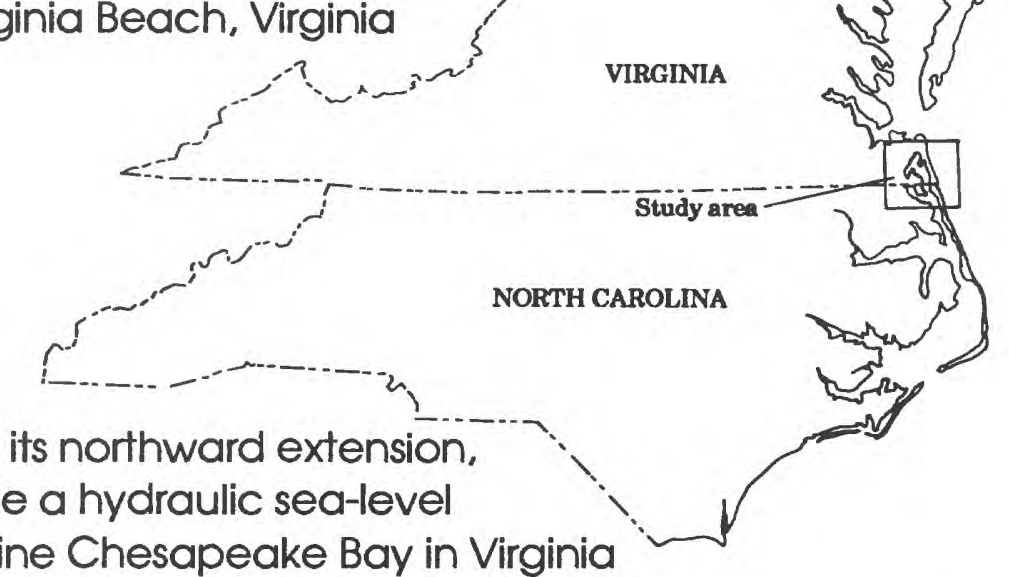

Problem: West Neck Creek and its northward extension, London Bridge Creek, provide a hydraulic sea-level connection between the saline Chesapeake Bay in Virginia and the relatively fresh waters of northern Currituck Sound in North Carolina. Recent completion of a bypass channel has led to concerns that the greater flow capacity of the bypass channel may bring more saline Chesapeake Bay water and Virginia Beach urban runoff into Currituck Sound during periods of prolonged northerly winds.

Objectives: To (1) define the flow regime of West Neck Creek, and (2) quantify and assess saltwater transport through the Creek.

Approach: An ultrasonic velocity meter will be used to determine the magnitude and direction of flow in the canal. Water-level recorders at each end of the canal will be used to characterize the water-surface slope in relation to wind speed and direction and to rainfall. Continuous records of salinity at each end of the canal will be used, along with flow records, to quantify the saltwater movement through the study reach.

Progress: The ultrasonic velocity meter (DCP) is operating. Station files have been established in ADAPS, and water year 1990 records are being processed. 
Prolect: (NC100) Leachate discharge at solid-waste disposal sites in Mecklenburg County, North Carolina

Lecation: Mecklenburg County, North Carolina

Project Chief: M.S. Davenport

Period of Project: $1989-94$

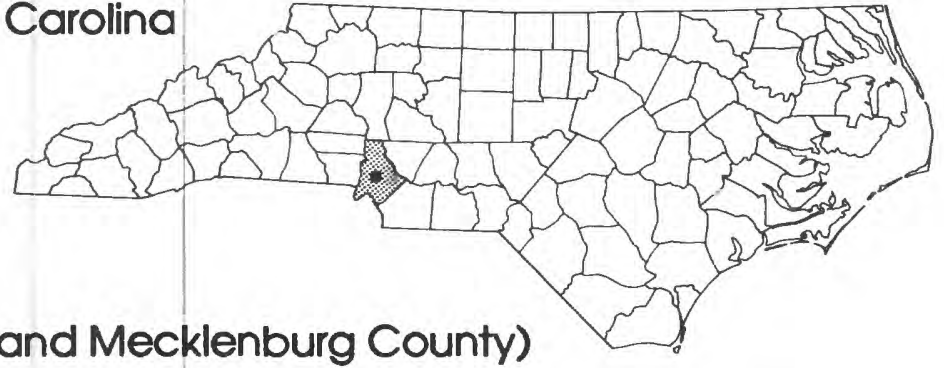

Cooperation: Local (City of Charlotte and Mecklenburg County)

Problem: The Charlotte-Mecklenburg County area is one of the most highly industrialized, rapidly growing areas in North Carolina. City-county solid-waste disposal sites are reaching capacity; new sites need to be located. Due to the complex hydrology of waste-disposal sites. State agencies are reluctant to permit new sites due to lack of scientific data on which to base decisions.

Objectives: To (1) characterize the quality, occurrence, and movement of ground water within the saturated zone and quantify vertical infiltration of water through the unsaturated zone; (2) estimate annual leachate discharge from landfills to adjacent drains and determine yields of selected constituents;

(3) determine occurrence and extent of leachate plume(s) and identify major plume constituents; and (4) evaluate existing monitoring networks to determine spatial and temporal suitability for achieving objectives 1-3.

Approach: Monitor ground-water levels and quality in areas of recent closure, long-term closure, and active landfilling. Construct depth profiles of selected constituent concentrations showing vertical and lateral spatial distribution. Measure infiltration rates through the unsaturated zone and below clay landfill caps. Determine concentration-discharge relationships. Estimate annual leachate discharge and annual yields of selected constituents. Determine occurrence and areal extent of leachate plumes using terrain conductivity and subsurface resistivity coupled with specific conductance measurements.

Progress: A majority of the wells and surface-water sampling sites have been installed. Data collection is ongoing from previous studies. 


\section{Reports:}

Eddins, W.H., and Crawford, J.K., 1984, Reconnaissance of water-quality characteristics of streams in the city of Charlotte and Mecklenburg County. North Carolina: U.S. Geological Survey Water-Resources Investigations Report 84-4308, $105 \mathrm{p}$.

Eddins, W.H., and Cardinell, A.P., 1987, Surface- and ground-water quality data at selected landfill sites in Mecklenburg County, North Carolina: U.S. Geological Survey Open-File Report 87-567, 393 p.

Cardinell, A.P., Barnes, C.R., Eddins, W.H., and Coble, R.W., 1989, Hydrologic environments and water-quality characteristics at four landfills in Mecklenburg County, North Carolina, 1980-86: U.S. Geological Survey Water-Resources Investigations Report 89-4035, 79 p. 
Project: NC101--Surface-water quality assessment for Region J, North Carolina

Lecation: North-central North Carolina

Prolect Chief: C.R. Barnes

Period of Project: $1988-1992$

Cooperation: Local (Triangle Area Water-Supply Monitoring Project Steering Committee)

Problem: The continued rapid development of the Research Triangle area (Region J) of North Carolina has led to concerns regarding the quality of surface-water supplies. There are no long-term regional water-quality monitoring data for many of the streams tributary to the Region's drinkingwater supplies. Many of these streams receive a complex mix of treated industrial and municipal wastes in addition to nonpoint urban and agricultural runoff.

Objectives: To (1) supplement the existing State data base for major ions, nutrients, and trace elements, (2) begin first regional data base on synthetic organic compounds, (3) document spatial differences in regional surfacewater quality, (4) determine temporal trends in water quality and examime causes of the trends, and (5) provide water-quality data to local planners and managers.

Approach: A 3-year, fixed-interval sampling program will be used to assess water quality at 20 stream and 11 reservoir sites. Constituents studied will include general water-quality indicators, major ions and nutrients, trace elements and organics. Eighteen stream sites will be gaged to provide continuous discharge data. Selected bed-sediment samples will be taken from 7 stream and 2 lake sites in the Haw River and Neuse River systems. High-flow samples at two selected sites will be analyzed for synthetic organic compounds.

Progress: Sampling has progressed as scheduled. Most water-quality constituents are within acceptable, expected ranges. Nutrient concentrations increased below populated areas. Trichloromethane and three pesticides (dieldrin, lindane, and diazinon) occurred frequently at low levels below wastewatertreatment plants. Concentrations of the synthetic organic compounds appear to be extremely low. Bed sediment samples indicated the presence of low levels of organochlorine compounds (DDT and PCB's). 
Prolect: NC102-Statewide reservoir sedimentation program

Lecation: Statewide

Project Chief: C.J. Weaver

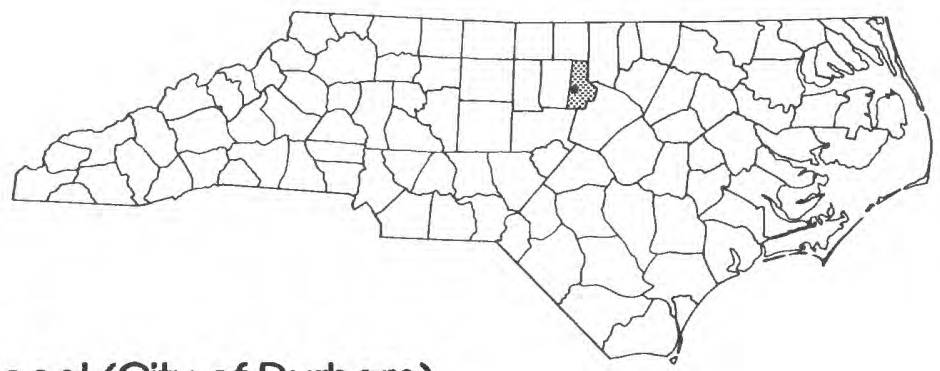

Cooperation: State (DEHNR) and local (City of Durham)

Problem: The natural accumulation of sediment on a reservoir bottom progressively reduces the usable storage. Faced with rising demand and the recurrence of droughts, reservoir managers need accurate information about deposition rates in order to plan for adequate supplies in the future. Another growing concern is the presence of toxic substances attached to finegrained sediments buried at the reservoir bottom and their ultimate effect on water quality and aquatic ecosystems. The North Carolina Department of Environment, Health, and Natural Resources wants to assess the threat posed to the quantity and quality of the State's water supply, and many municipalities throughout the State are concerned about their own systems.

Objectives: To (1) determine present bathymetry and storage, (2) quantify present and historic sedimentation rates, and (3) characterize physical properties of inflowing, outflowing, and bottom sediments. The long-term objective is an evaluation of the relation between sedimentation rates and watershed and reservoir characteristics.

Approach: Lake Michie, Durham County, will be the first reservoir studied. Results of this study will provide (1) a basis for the standardization of data-collection techniques and procedures at other sites and (2) guidance for the longrange reservoir sedimentation program. Bathymetry will be determined with an automated positioning system and integrated depth finder. Maps will be drawn with the aid of a contouring software package. Historic deposition rates will be determined from the calculated loss of storage since previous surveys. Current delivery and deposition rates will be measured directly using transport rates determined at continuous-record discharge gaging stations at the reservoir inflow and outflow streams. Cores will be taken and particle-size analyses made to characterize physical properties of sediment on an areal basis. 
Progress: In April 1990, 28 core samples were obtained throughout the length of the lake bottom and in February 1991, a bathymetric and geophysical survey of Lake Michie was conducted to define current bottom depths and locate points where core samples of bottom sediments could be retrieved. These data are being used to prepare a contour map of the lake bottom.

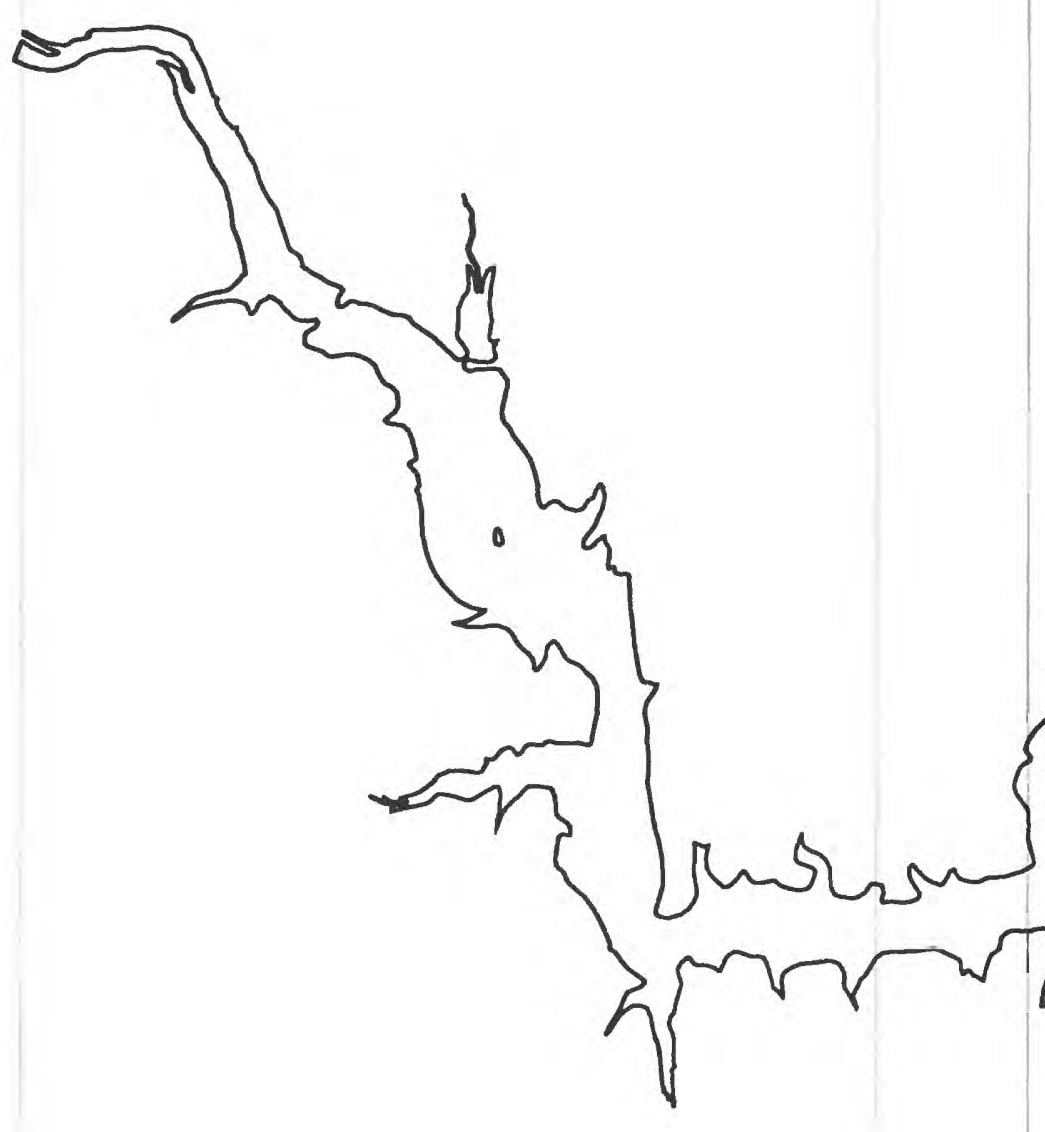

Digitized base map of Lake Michie near Durham, North Carolina. (Map compiled by Landmark Engineering Company, Cary, North Carolina) 
Project: NC103--Hydrology of the Sand Hills aquifer

Location: Moore and Hoke Counties, North Carolina

Prolect Chief: R.W. Coble

Period of Project: $1990-91$

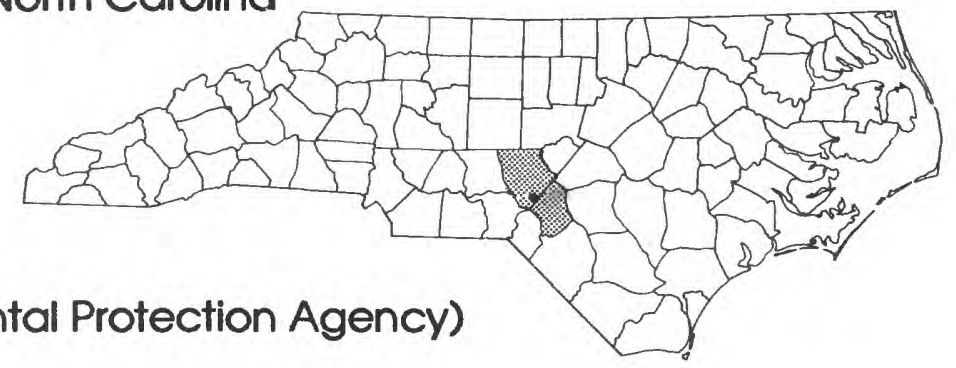

Cooperation: Federal (U.S. Environmental Protection Agency)

Problem: Disposal of pesticides at six sites in the Aberdeen area resulted in contamination of soil and ground water. Lindane and alpha-benzene hexachloride have been identified in water from several municipal wells on the east side of Aberdeen Creek. Details of the hydrogeology and groundwater flow are insufficiently known to answer questions posed by the U.S. Environmental Protection Agency about ground-water flow in the Aberdeen area, the potential for ground-water movement from the west side of town to the east side beneath Aberdeen Creek, and the source areas of water moving to the contaminated muncipal wells.

Objectlves: To determine the effects of the ground-water contamination in the Aberdeen area, it will be necessary to (1) characterize the ground-water flow in the vicinity of Aberdeen, (2) determine the effects of pumping wells (specifically municipal wells) on the ground-water flow, (3) determine if ground-water can move from the west side of Aberdeen Creek to municipal wells on the east side, and (4) determine the source areas for water withdrawn from the Aberdeen municipal wells.

Approach: Ground-water flow will be characterized by constructing a potentiometric surface map using water-level data from inventoried wells and piezometers constructed for this study. The effects of pumping wells on ground-water flow will be determined by constructing a variable-grid, finite-difference ground-water flow model. Hydrogeologic analysis will come from existing logs and those from test holes. Water-use data will be collected for model input. Scenarios of varying pumping and aquifer coefficients will reveal if flow beneath the creek is possible and reasonable. The flow model will define cones of depression around and flow paths to municipal wells using a particle-tracking package. 
Progress: Field work and data collection are complete. Test holes have been drilled and 37 piezometers have been constructed at 8 sites. Test-hole data and 40 geophysical logs were used to define the hydrogeology of 4 aquifers. Constant-rate aquifer tests and slug tests were performed. Potentiometric-surface maps have been constructed from water-level data from 150 wells. Construction of a ground-water flow model is in progress. 


\section{SELECTED PUBLICATIONS ON WATER RESOURCES}

Selected publications on water resources in North Carolina are listed on the following pages; many of the reports are available for public inspection at one of the offices shown in the figure inside the front cover of this report, as well as at larger public and university libraries across the State. For information on the availability of these publications, contact the District Chief, U.S. Geological Survey, 3916 Sunset Ridge Road, Raleigh, North Carolina 27607.

The following list includes U.S. Geological Survey publications, reports from cooperating agencies, and outside publications, such as professional journal articles and symposium proceedings, prepared by members of the District staff. New reports published or released by the USGS are announced monthly in "New Publications of the U.S. Geological Survey." Subscriptions to this monthly list are available upon request to the U.S. Geological Survey, National Center, Mail Stop 582, Reston, Virginia 22092.

Most USGS publications are available at cost from the U.S. Geological Survey, Books and Open-File Reports, Federal Center, Box 25425, Building 810. Denver, Colorado 80225 . Some of the types of USGS publications available include: Bulletins, Open-File Reports (books and maps), Water-Resources Investigations Reports (books and maps), Water-Supply Papers, Professional Papers, Techniques of Water-Resources Investigations, and Selected Papers in the Hydrologic Sciences. Circulars are available at no charge upon request.

USGS maps, such as Hydrologic Investigations Atlases, Hydrologic Unit Maps, and topographic maps can be purchased from the U.S. Geological Survey, Map Distribution Center, Federal Center, Box 25286, Denver Colorado 80225. Some of these maps are also available for inspection at the USGS offices listed on the inside of the front cover.

Listed reports prepared by the U.S. Geological Survey in cooperation with, and published by, State or local agencies may be inspected at or obtained from the cooperating agency. The U.S. Geological Survey office in Raleigh maintains a loan library that contains copies of some of these reports. In addition, many of the reports are available for inspection at the larger public and university libraries throughout the State. 
The North Carolina Department of Environment, Health, and Natural Resources has an extensive library of publications relating to water resources in North Carolina. Most USGS publications originating from the North Carolina District also are available for inspection there. The North Carolina Department of Environment, Health, and Natural Resources is located in the Archdale Building, 512 N. Salisbury Street, Raleigh, North Carolina 27601.

Professional journal articles and symposium proceedings are available from the publisher or from the professional organization sponsoring the symposium. Reprints of articles or symposium proceedings papers can often be obtained by contacting the author directly.

Prior to the 1975 water year, records of streamflow, ground-water levels, and quality of water were published in the USGS Water-Supply Paper series. However, these data are currently combined and published annually for each State in the U.S. Geological Survey Water-Data Report series. The title of the North Carolina annual data report is "Water-Resources Data for North Carolina-Water Year (date): U.S. Geological Survey Water-Data Report NC-(19_-1." It contains streamflow data, water-quality data for surface water and ground water, and ground-water level data from the basic network of observation wells.

The USGS also publishes such special reports as the U.S. Geological Survey Yearbook, which provides a comprehensive description of the Federal Government's largest earth-science agency. Summaries of research in progress and results of completed investigations are published each fiscal year in the Professional Paper series, "Geological Survey Research." Both publication series are sold by the U.S. Geological Survey, Books and Open-File Reports, Federal Center, Box 25425, Building 810, Denver, Colorado 80225.

Further information regarding publications of the U.S. Geological Survey is available from the District Chief, U.S. Geological Survey, Water Resources Division, 3916 Sunset Road, Raleigh, North Carolina 27607. 


\section{Surface Water}

\section{Data Reports}

\section{Streamflow data}

Daily streamflow records, beginning with water year 1975, are released in the annual publication, "Water Resources Data for North Carolina, Water Year 19." Before 1961, this was an annual series in three parts: Part 2-A contained data for streams draining to the Atlantic Ocean; Part 3-A contained data for streams in the New River basin; and Part 3-B contained data for streams in the Tennessee River basin. For the period 1961-70, 5-year compilations were published containing data for North Carolina. The parts for this period are Part 2, Volume 1, containing data for streams draining to the Atlantic Ocean: Part 3, Volume 2, containing data for streams in the New River basin; and Part 3. Volume 4, containing data for streams in the Tennessee River basin. Also, from 1961 through 1974, daily streamflow records were released annually in a single open-file report covering the entire State.

\section{Floods}

The U.S. Geological Survey outlines flood-prone areas on topographic maps as part of a recent nationwide Federal program for managing flood losses. In North Carolina, 480 flood-prone area maps have been completed. These maps are available from the District Chief, U.S. Geological Survey, 3916 Sunset Road, Raleigh, North Carolina 27607. Basic-data reports pertaining to surface-water resources are listed below:

Jackson, N.M., Jr., Wollin, E.G., Reeder, H.E., and Dillard, T.E., 1977 (revised), Thomas, N.O., and Bonham. W.G., 1976. Annual maximum peak stages and discharges of North Carolina streams: U.S. Geological Survey Open-File Report 77-367, 226 p.

Mason, R.R., and Hill, C.L., 1988, Programs for generating data tables for the annual water-resources data report of the U.S. Geological Survey: U.S. Geological Survey Open-File Report 88-173, 13 p.

Meikle, R.L., 1983, Drainage areas of selected sites on North Carolina streams: U.S. Geological Survey Open-File Report 83-211, 163 p.

Thomas, N.O., 1973, Summaries of streamflow records: North Carolina Department of Natural and Economic Resources, Office of Water and Air Resources, 303 p. 
Thomas, N.O., and Jackson, N.M., Jr., 1981, Manual for leveling at gaging stations in North Carolina: U.S. Geological Survey Open-File Report 81-1104, 37 p.

U.S. Geological Survey, 1961-64. Surface-water records of North Carolina.

1965-74, Water-resources data for North Carolina--Part 1, Surface-water records.

1975-90. Water-resources data for North Carolina, water year 19_: U.S. Geological Survey Water-Data Report NC-19_-1.

Yonts, W.L., 1971, Low-flow measurements of North Carolina streams: North Carolina Department of Water and Air Resources, $236 \mathrm{p}$.

\section{Interpretive Reports}

Arteaga, F.E., and Hubbard, E.F., 1974, Evaluation of reservoir sites in North Carolina, Regional relations for estimating the reservoir capacity needed for a dependable water supply: U.S. Geological Survey Water-Resources Investigations 46-74, $60 \mathrm{p}$.

Bales, J.D., 1987, Review of concepts and data relevant to hydrodynamic and water-quality modeling of the Albemarle-Pamlico Sound, North Carolina, in Duffy, M.A., ed., Proceedings of the workshop on hydrodynamic and waterquality models for the Albemarle-Pamlico estuarine study: Raleigh, North Carolina Department of Natural Resources and Community Development, Report No. 87-03, p. 13-28.

1988. Fractional step method for two-dimensional estuarine transport, in Abt, S.R., and Gessler, Johannes, eds., Hydraulic engineering. Proceedings of the 1988 national conference: New York, American Society of Civil Engineers, p. 1182-1187.

1989a. Flows and flow patterns in the Pamlico and Neuse River estuaries (abs.), in Holman, R.E., ed. . Project abstracts for period 1989-1990. AlbemarlePamlico estuarine study: Raleigh, North Carolina Department of Environment, Health, and Natural Resources, Project no. 89/08, September 1989, p. 8.

1989b, Off-site effects of water-control structures (abs.), in Holman, R.E.. ed. Project abstracts for period 1989-1990, Albemarle-Pamlico estuarine study: Raleigh, North Carolina Department of Environment, Health, and Natural Resources, Project no. 89/08, September 1989, p. 9. 
1990a, Data-collection program for Pamlico River estuary model calibration and validation, in Spaulding, M.L., ed., Estuarine and coastal modeling, Proceedings of the conference, Newport, R.I., November 15-17, 1989: New York, American Society of Civil Engineers, p. 492-501.

1990b. Hydrodynamics and circulation of the Pamllco River and Neuse River estuarles (abs.), in North Carolina Department of Environment, Health, and Natural Resources, Project abstracts - FY89 and FY90: Raleigh, North Carolina Department of Environment, Health, and Natural Resources, Project no. 90-18, p. 26.

Billingsley, G.A., Fish, R.E., and Schipf, R.G., 1957, Water resources of the Neuse River basin, North Carolina: U.S. Geological Survey Water-Supply Paper 1414. $89 \mathrm{p}$.

Coble, R.W., 1979, A technique for estimating heights reached by the 100-year flood on unregulated, nontldal streams in North Carolina: U.S. Geological Sunvey Water-Resources Investigations 79-69, 14 p.

Daniel, C.C., III, 1977. Digital flow model of the Chowan River estuary, North Carolina: U.S. Geological Survey Water-Resources Investigations 77-63, 84 p.

1978, Land use, land cover, and drainage on the Albemarle-Pamlico peninsula, eastern North Carolina, 1974: U.S. Geological Survey Water-Resources Investigations 78-134, 2 sheets.

1980, Hydrology, geology and soils of pocosins: A comparison of natural and altered systems, in Richardson, C.J., ed., Pocosin wetlands: An integrated analysis of Coastai Plain freshwater bogs in North Carolina: Stroudsburg. Pa., Hutchinson Ross Publishing Company, p. 69-108.

Eddins, W.H., and Jackson, N.M., Jr., 1980, A technique for estimating flood heights on small streams in the city of Charlotte and Mecklenburg County, North Carolina: U.S. Geological Survey Water-Resources Investigations 80-106, 16p.

Fish, R.E., LeGrand, H.E., and Billingsley, G.A., 1957, Water resources of the YadklnPee Dee RIver basin, North Carolina: U.S. Geological Survey Water-Supply Paper 1415, $115 \mathrm{p}$. 
Giese, G.L., 1976, Thermal loading of Hyco Lake, North Carolina--The effect of heated water on temperature and evaporation, 1966-74: U.S. Geological Survey Water-Resources Investigations 76-48, $46 \mathrm{p}$.

Giese, G.L., Wilder, H.B., and Parker, G.G., Jr., 1985, Hydrology of major estuaries and sounds of North Carolina: U.S. Geological Survey Water-Supply Paper 2221, $107 \mathrm{p}$.

Goddard, G.C., Jr., 1963, Water-supply characteristics of North Carolina streams: U.S. Geological Survey Water-Supply Paper 1761, 223 p.

Goddard, G.C., Jr., Jackson, N.M., Jr., Hubbard, E.F., and Hinson, H.G., 1970, A proposed streamflow data program for North Carolina: U.S. Geological Suney Open-File Report, $69 \mathrm{p}$.

Gunter, H.C., Mason, R.R., and Stamey, T.C., 1987, Magnitude and frequency of floods in rural and urban basins of North Carolina: U.S. Geological Survey Water-Resources Investigations Report 87-4096, $52 \mathrm{p}$.

Haire, W.J., 1968, Floods on Boone and Winkler Creeks at Boone, North Carolina: U.S. Geological Survey Hydrologic Investigations Atlas HA-323.

1968, Floods on Little Buffalo Creek at West Jefferson, North Carolina: U.S. Geological Sunvey Hydrologic Investigations Atlas HA-331.

Heath, R.C., 1978, Floods and droughts, The worst are yet to be: North Carolina Water Resources Research Institute (brochure).

Hinson, H.G., 1965, Floods on small streams in North Carolina, Probable magnitude and frequency: U.S. Geological Survey Circular 517,7 p.

Hubbard, E.F., and Stamper, W.G., 1972, Movement and dispersion of soluble pollutants in the northeast Cape Fear estuary, North Carolina: U.S. Geological Survey Water-Supply Paper 1873-E, 31 p.

Jackson, N.M., Jr., 1968, Flow of the Chowan River, North Carolina, A study of the hydrology of an estuary affected primarily by winds: U.S. Geological Survey Open-File Report, 29 p.

Lindskov, K.L., 1974, Movement and dispersion of soluble materials in Saiem Creek, Muddy Creek, and Yadkin River between Winston-Salem and Salisbury, North Carolina: U.S. Geological Survey Water-Resources Investigations 6-74, 26 p. 
Martens, L.A., 1968, Flood inundation and effects of urbanization in metropolitan Charlotte, North Carolina: U.S. Geological Survey Water-Supply Paper 1591-C. $60 \mathrm{p}$.

Mason, R.R., and Jackson, N.M., Jr., 1985, Cost-effectiveness of the stream-gaging program in North Carolina: U.S. Geological Survey Water-Resources Investigations Report 85-4036, 109 p.

1985, North Carolina surface-water resources, in National water summary 1985-Hydrologic events and surface-water resources: U.S. Geological Survey Water-Supply Paper 2300, p. 355-360.

McMaster, W.M., and Hubbard, E.F., 1970, Water resources of the Great Smokey Mountains National Park, Tennessee and North Carolina: U.S. Geological Survey Hydrologic Investigations Atlas HA-42O.

Putnam, A.L., 1972, Effects of urban development on floods in the Piedmont Province of North Carolina: U.S. Geological Survey Open-File Report, 87 p.

Putnam, A.L., and Lindskov, K.L., 1973, Water resources of the upper Neuse River basin, North Carolina: U.S. Geological Survey Water-Resources Investigations $12-73,68 p$.

Simmons, C.E., and Aldridge, M.C., 1980, Hydrology of the Chicod Creek basin, North Carolina, prior to channel improvements: U.S. Geological Survey Open-File Report 80-680, 27 p.

Stamey, T.C., 1985, Frequency and duration of flooding of Grove Creek near Kenansvilie, North Carolina, for present and proposed restored channel conditions: U.S. Geological Survey Water-Resources Investigations Report $85-4298,52 \mathrm{p}$.

1989a, Effects of channel relocation and proposed bridge construction on floodflows of the Catawba River near Marion, North Carolina: U.S. Geological Survey Water-Resources Investigations Report 88-4207, 16 p.

1989b. Sediment transport and accretion and the hydrologic environment of Grove Creek near Kenansville, North Carolina: U.S. Geological Survey WaterResources Investigations Report 89-4086، $30 \mathrm{p}$. 
Stamper, W.G., 1975, Flood mapping in Charlotte and Mecklenburg County, North Carolina: U.S. Geological Survey Open-File Report, 21 p.

Stewart, J.M., Heath, R.C., and Morris, J.N., 1978, Floods in western North Carolina November 1977, A lesson for the future: North Carolina Water Resources Research Institute.

Turner, J.F., Jr., 1966, Evaporation study in a humid region, Lake Michie, North Carolina: U.S. Geological Survey Professional Paper 272-G. p. 137-150.

U.S. Geological Survey, 1975, Hydrologic unit map-1974. State of North Carolina: U.S. Geological Survey, scale 1:500,000, 1 sheet.

Watkins, S.A., and Simmons, C.E., 1984, Hydrologic conditions in the Chicod Creek basin, North Carolina, before and during channel modifications, 1975-81: U.S. Geological Survey Water-Resources Investigations Report 84-4025, 36 p.

Yonts, W.L., and Giese, G.L., 1974. The effect of heated water on the temperature and evaporation of Hyco Lake, North Carolina, 1966-72: U.S. Geological Survey Water-Resources Investigations 11-74,38 p.

Yonts, W.L., Giese, G.L., and Hubbard, E.F., 1973, Evaporation from Lake Michle, North Carolina, 1961-71: U.S. Geological Survey Water-Resources Investigations 38-73, $27 \mathrm{p}$.

\section{Water Quality}

\section{Data Reports}

North Carolina water-quality data have been released annually, since water year 1975 (October 1974-September 1975), in the publication, "Water Resources Data for North Carolina, Water Year 19_." Additional basic-data reports pertaining to water quality are listed below:

Bales, J.D., and Nelson, T.M., 1988, Bibliography of hydrologic and water-quality investigations conducted in or near the Albemarle-Pamlico Sounds region, North Carolina: U.S. Geological Survey Open-File Report 88-480, 148 p.

Davenport, M.S., 1988, Surface-water and water-quality data from selected streams and treated waters in the Greensboro area, North Carolina, 1986-87: U.S. Geological Survey Open-File Report 88-169, 462 p. 
Eddins, W.H., and Cardinell, A.P., 1987, Surface- and ground-water quality data at selected landfill sites in Mecklenburg County, North Carolina, 1980-86: U.S. Geological Survey Open-File Report 87-564, 393 p.

Hill, C.L., 1989, Hydrologic and chemical-quality data from four rural basins in Gullford County, North Carolina, 1985-88: U.S. Geological Survey Open-File Report 89-578, $105 p$.

Knobel, L.L., 1985. Ground-water-quality data for the Atlantic Coastal Plain: New Jersey, Delaware, Maryland, Virginia and North Carolina: U.S. Geological Survey Open-File Report 85-154, 84 p.

North Carolina Department of Conservation and Development 1947-56, Chemical and physical character of surface water of North Carolina: North Carolina Department of Conservation and Development Bulletin 52, v. 1. (1944-45); v. 2. (1945-56); v. 3. (1946-47); v. 4. (1947-48); v. 5. (1948-49); v. 6. (1949-50); v. 7. (1950-51); v. 8. (1951-52); v. 9. (1952-53); v. 10 , (1953-54); v. 11, (1954-55); v. 12, (1955-56).

North Carolina Department of Water Resources, 1956-67, Chemical and physical character of surface waters of North Carolina: Division of Stream Sanitation and Hydrology, North Carolina Department of Water Resources Bulletin 1. v. I. (1956-57); v. II. (1957-58); v. III, (1958-59); v. IV. (1959-60); v. V. (1960-61); v. VI, (1961-62); v. VII, (1962-63); v. VIII, (1963-64); v. IX. (1964-65); v. X. (1965-66).

1961-69. Chemical and physical character of municipal water supplies in North Carolina: Division of Stream Sanitation and Hydrology, North Carolina Department of Water Resources Bulletin 2 (1961); Bulletin 2, supp. 1 (1962); Bulletin 2, supp. 2 (1964); Bulletin 2, supp. 3 (1965); Bulletin 3 (1969).

U.S. Geological Sunvey, 1964-74, Water-resources data for North Carolina--Part 2. Water-quality records: U.S. Geological Survey.

Wilder, H.B., and Slack, L.J., 1971, Summary of data on chemical quality of streams of North Carolina, 1943-67: U.S. Geological Survey Water-Supply Paper 1895-B, 236 p.

Woodard, T.H., 1970, Summary of data on temperature of streams in North Carolina, 1943-67: U.S. Geological Survey Water-Supply Paper 1895-A, 39 p. 


\section{Interpretive Reports}

Bales, J.D., 1989, Land drainage and estuarine salinity response, in Ports, M.A., ed. Hydraulic engineering. Proceedings of the 1989 national conference on hydraulic engineering: New York, American Society of Civil Engineers, p. 200-205.

Berry, E.L., 1970, Ground-water quality in Staniy County, North Carolina: North Carolina Department of Water and Air Resources Ground-Water Circular 15.

Cardinell, A.P., Barnes, C.R., Eddins, W.H., and Coble, R.W., 1989, Hydrologic environments and water-quality characteristics at four landfills in Mecklenburg County, North Carolina, 1980-86: U.S. Geological Survey Water-Resources Investigations Report 89-4035, 79 p.

Crawford, J.K., 1985, Water-quality characteristics for selected sites on the Cape Fear River, North Carolina, 1955-80, variability, loads, and trends of selected constituents: U.S. Geological Survey Professional Paper 2185-F, $44 \mathrm{p}$.

Crawford, J.K., and Lenat, D.R., 1989, Effects of land use on the water quality and biota of three streams in the Piedmont Province of North Carolina: U.S. Geological Survey Water-Resources Investigations Report 89-4007, 67 p.

Daniel, C.C., III, Wilder, H.B., and Weiner, M.S., 1982, Water quality of the French Broad River, North Carolina, An analysis of data collected at Marshall, 1958-77: U.S. Geological Survey Professional Paper 2185-C. 28 p.

Davenport, M.S., 1989, Water quality in Reedy Fork and Buffalo Creek basins in the Greensboro area, North Carolina, 1986-87: U.S. Geological Survey WaterResources Investigations Report 88-4210, 81 p.

Eddins, W.H., and Crawford, J.K., 1984, Reconnaissance of water-quality characteristics of streams in the city of Chariotte and Meckienburg County, North Carolina: U.S. Geological Survey Water-Resources Investigations Report 84-4308, $105 \mathrm{p}$.

Garrett, R.G., 1990a, Water-quality characteristics of inflow to and outflow from B. Everett Jordan Lake, North Carolina, 1982-86: U.S. Geological Survey Water-Resources Investigations Report 90-4096, 49 p. 
1990b. Water-quality characteristics of inflow to and outflow from Falls Lake, North Carolina, 1982-87: U.S. Geological Survey Water-Resources Investigations Report 90-4097, $56 \mathrm{p}$.

Gurtz, M.E., 1989, Ecological aspects of the National Water-Quality Assessment program, in Pederson, G.L., and Smith, M.M., compilers, U.S. Geological Survey second national symposium on water quality: Abstracts of the technical sessions, Orlando, Florida, November 12-17, 1989: U.S. Geological Survey Open-File Report 89-409, p. 33-34.

Harned, D.A., 1982, Water quality of the Neuse River, North Carolina, variability, pollution loads, and long-term trends: U.S. Geological Survey Professional Paper 2185-D, $44 \mathrm{p}$.

1988, Effects of highway runoff on streamflow and water quality in the Sevenmile Creek basin, a rural area in the Piedmont Province of North Carolina, July 1981 to July 1982: U.S. Geological Suney Water-Supply Paper 2329, $33 \mathrm{p}$.

Harned, D.A., Daniel, C.C., III, and Crawford, J.K., 1981, Methods of discharge compensation as an aid to the evaluation of water quality trends: Water Resources Research, v. 17, no. 5, p. 1389-1400.

Harned, D.A., and Davenport, M.S., 1989, Water-quality trends of the AlbemarlePamlico estuarine system, North Carolina, in Pederson, G.L., and Smith. M.M., compilers, U.S. Geological Survey second national symposium on water quality: Abstracts of the technical sessions, Orlando, Florida, November 12-17, 1989: U.S. Geological Survey Open-File Report 89-409, p. 35.

1990. Water-quality trends and basin activities and characteristics for the Albemarle-Pamlico estuarine system, North Carolina and Virginia: U.S. Geological Survey Open-File Report 90-398, 164 p.

Harned, D.A., and Meyer D., 1983, Water quality of the Yadkin-Pee Dee River system. North Carolina--Variability, pollution loads, and long-term trends: U.S. Geological Survey Professional Paper 2185-E, 71 p.

Heath, R.C., 1975, Hydrology of the Albemarle-Pamlico region, North Carolina, A preliminary report on the impact of agricultural developments: U.S. Geological Survey Water-Resources Investigations 9-75, $98 \mathrm{p}$. 
Hill, C.L., 1986, Monitoring the effects of land-management practices on sediment and chemical transport in northeastern Guilford County, North Carolina (abs.), in Proceedings of the fourth annual meeting of the Weed Science Society of North Carolina: Raleigh, N.C., p. 62-63.

1987. Monitoring the effects of land-management practices on water quality in Guilford County, North Carolina, in Proceedings of the American Water Resources Association symposium, May 1987: American Water Resources Association, p. 137-147.

1989, The effects of land-management practices on surface- and groundwater quality in rural northeastern Guilford County, North Carolina, in Pederson, G.L., and Smith, M.M., compilers, U.S. Geological Survey second national symposium on water quality: Abstracts of the technical sessions, Orlando, Florida, November 12-17, 1989: U.S. Geological Survey Open-File Report 89-409, p. 38.

1991, Effects of land-management practices on sediment yields in northeastern Guilford County, North Carolina: U.S. Geological Survey WaterResources Investigations Report 90-4127, 40 p.

LeGrand, H.E., 1958, Chemical character of water in the igneous and metamorphic rocks of North Carolina: Economic Geology, v. 53, no. 2, p. 178-189.

Lloyd, O.B., Jr., and Daniel, C.C., III, 1988, Distribution, source, and significance of selected organic compounds in water from the Castle Hayne aquifer, Cherry Point, North Carolina, in Proceedings of the symposium on coastal water resources, Wilmington, North Carolina, May 22-25, 1988: Bethesda, Md. . American Water Resources Association, p. 519-530.

Mason, R.R., 1988, Ground-water and surface-water conditions in the Chicod Creek basin, North Carolina, before, during, and after channel modifications, in Proceedings of the symposium on coastal water resources, Wilmington, North Carolina, May 22-25, 1988: Bethesda, Md., American Water Resources Association, p. 419-427.

Mason, R.R., Jr., Simmons, C.E., and Watkins, S.A., 1990, Effects of channel modifications on the hydrology of Chicod Creek basin, North Carolina, 197587: U.S. Geological Survey Water-Resources Investigations Report 90-4031, $83 \mathrm{p}$. 
Reeder, H.E., 1970, Sedimentation in Third Creek sub-watershed no. 7A, North Carolina: U.S. Geological Survey Open-File Report.

1973. Sediment resulting from construction of an interstate highway in the Pledmont area of North Carolina: U.S. Geological Survey Open-File Report, $27 \mathrm{p}$.

Simmons, C.E., 1975, Sediment characteristics of streams in eastern Piedmont and western Coastal Plain regions of North Carolina: U.S. Geological Sunvey Water-Supply Paper 1798-O, $32 \mathrm{p}$.

1980, Quality of water in the Black River near Dunn, North Carolina, and ground-water levels adjacent to the river prior to channel excavation in 1976-79: U.S. Geological Survey Open-File Report 80-425, 18 p.

1988. Sediment characteristics of North Carolina streams, 1970-79: U.S. Geological Survey Open-File Report 87-701 (pending publication as WaterSupply Paper 2364), $130 \mathrm{p}$.

Simmons, C.E., and Heath, R.L., 1982, Water-quality characteristics of streams in forested and rural areas of North Carolina: U.S. Geological Survey Professional Paper 2185-B, 33 p.

Simmons, C.E., and Watkins, S.A., 1982, The effects of channel excavation on water-quality characteristics of the Black River and ground-water levels near Dunn, North Carolina: U.S. Geological Survey Water-Resources Investigations Report 82-4083, $28 \mathrm{p}$.

Treece, M.W., and Bales, J.D., 1990, Hydrologic and water-quality effects of artificial-drainage control (abs.), in North Carolina Department of Environment, Health, and Natural Resources, Project abstracts - FY89 and FY90: Raleigh, North Carolina Department of Environment, Health, and Natural Resources, Project no. 90-18, p. 27.

Wilder, H.B., 1972, Investigation of the occurrences and transport of arsenic in the upper Sugar Creek watershed, Charlotte, North Carolina: U.S. Geological Survey Professional Paper 800-D. p. 205-210.

Wilder, H.B., and Hubbard, E.F., 1968, Sea-water encroachment in the Cape Fear River estuary, North Carolina: U.S. Geological Survey Open-File Report. 
Wilder, H.B., Robinson, T.M., and Lindskov, K.L., 1978, Water resources of northeast North Carolina: U.S. Geological Survey Water-Resources Investigations 77-81, $113 \mathrm{p}$.

Wilder, H.B., and Simmons, C.E., 1982, Program for evaluating stream quality in North Carolina: U.S. Geological Survey Professional Paper 2185-A, 15 p.

Wilder, H.B., and Slack, L.J., 1971, Chemical quality of water in streams of North Carolina: U.S. Geological Survey Hydrologic Investigations Atlas HA-439.

Winner, M.D., Jr., and Simmons, C.E., 1977. Hydrology of Creeping Swamp watershed, North Carolina, with reference to potential effects of stream channelization: U.S. Geological Survey Water-Resources Investigations 77-26, 54 p.

\section{Ground Water}

\section{Data Reports}

Prior to 1975. ground-water levels and artesian pressures in observation wells were published in the Water-Supply Papers (WSP) listed in the following table. Since 1975, publication has been in the annual water-data report series which are distributed each year by the District office in Raleigh.

\begin{tabular}{rrrrrrrr}
\hline Year & WSP & Year & WSP & Year & WSP & Year & WSP \\
1935 & 777 & 1941 & 937 & 1947 & 1097 & 1953 & 1266 \\
1936 & 817 & 1942 & 945 & 1948 & 1127 & 1954 & 1322 \\
1937 & 840 & 1943 & 987 & 1949 & 1157 & 1955 & 1405 \\
1938 & 845 & 1944 & 1017 & 1950 & 1166 & $1956-58$ & 1538 \\
1939 & 886 & 1945 & 1024 & 1951 & 1192 & $1959-63$ & 1803 \\
1940 & 907 & 1946 & 1072 & 1952 & 1222 & $1964-68$ & 1978 \\
& & & & & & $1969-73$ & 2171 \\
\hline
\end{tabular}

Coble, R.W. Strickland, A.G., and Bailey, M.C., 1989, Ground-water level data for North Carolina--1987: U.S. Geological Survey Open-File Report 89-68, 152 p.

Floyd, E.O., and Long. A.T., 1970. Well records and other basic ground-water data, Craven County, North Carolina: North Carolina Department of Water and Air Resources, Division of Ground Water, Ground-Water Circular 14, 107 p. 
Murray, L.C., Jr., and Daniel, C.C., III, 1990, Hydrogeologic and water-quality data from well clusters near the wastewater-treatment plant, U.S. Marine Corps Air Station, Cherry Point, North Carolina: U.S. Geological Survey Open-File Report 89-615, $56 \mathrm{p}$.

\section{interpretive Reports}

Bain, G.L., 1966, Geology and ground-water in the Durham area, North Carolina: North Carolina Department of Water Resource, Division of Ground Water, Ground-Water Bulletin 7, 147 p.

1970, Geology and ground-water resources of New Hanover County, North Carolina: North Carolina Department of Water and Air Resources, Division of Ground Water, Ground-Water Bulletin 17, 79 p.

Berry, E.L., 1970, Ground water quality in Staniy County, North Carolina: North Carolina Department of Water and Air Resources, Division of Ground Water, Ground Water Circular 15, 24 p.

Blankenship, R.R., 1965, Reconnaissance of the ground-water resources of the Southport-Elizabethtown area, North Carolina: North Carolina Department of Water Resources, Division of Ground Water, Ground-Water Bulletin No. 6. $47 \mathrm{p}$.

Brockman, A.R., Lyke, W.L., Winner, M.D., Jr., 1989, Potentiometric surface of the Peedee aquifer in the central Coastal Plain of North Carolina. December 1986: U.S. Geological Survey Water-Resources Investigations Report 87-4236, 1 sheet.

Brown. P.M., 1958. Well logs from the Coastal Plain of North Carolina: North Carolina Department of Conservation and Development, Division of Mineral Resources, Bulletin No. 72, 68 p.

1959. Geology and ground-water resources in the Greenville area, North Carolina: North Carolina Department of Conservation and Development. Division of Mineral Resources, Bulletin No. 73, 87 p:

Brown. P.M., 1960, Ground-water supply of Cape Hatteras National Seashore recreational area: North Carolina Department of Water-Resources, Report Investigations 1. 
Brown, P.M., Miller, J.A., and Swain, F.M., 1972, Structural and stratigraphic framework and spatial distribution of the permeability of the Atlantic Coastal Plain, New York to North Carolina: U.S. Geological Survey Professional Paper 796, $79 \mathrm{p}$.

Cardinell, A.P., Harned, D.A., and Berg, S.A., 1990, Continuous seismic reflection profiling of hydrogeologic features beneath New River, Camp Lejeune, North Carolina: U.S. Geological Survey Water-Resources Investigations Report 894195, $33 \mathrm{p}$.

Coble, R.W., Giese, G.L., and Eimers, J.L., 1984, North Carolina ground-water resources, in National water summary 1984--Hydrologic events, selected waterquality trends, and ground-water resources: U.S. Geological Survey WaterSupply Paper 2275, p. 329-334.

Coble, R.W., Giese, G.L., and Winner, M.D., Jr., 1987, Application of Regional Aquifer System Analysis study results to ground-water management in North Carolina, in Vecchioli, John, and Johnson, A.I., eds., Regional aquifer systems of the United States, Aquifers of the Atlantic and Gulf Coastal Plain: Bethesda, Md. American Water Resources Association, Monograph Series No. 9. p. 39-49.

Daniel, C.C., III, 1989, Statistical analysis relating well yield to construction practices and siting of wells in the Piedmont and Blue Ridge Provinces of North Carolina: U.S. Geological Survey Water-Supply Paper 2341-A, 27 p. 1990. Evaluation of site-selection criteria, well design, monitoring techniques, and cost analysis for a ground-water supply in Piedmont crystalline rocks, North Carolina: U.S. Geological Survey Water-Supply Paper 2341-B, 35 p.

Daniel, C.C., III, and Payne, R.A., 1990, Hydrogeologic unit map of the Piedmont and Blue Ridge Provinces of North Carolina: U.S. Geological Survey WaterResources Investigations Report 90-4035, scale 1:500,000, 1 sheet.

Daniel, C.C., III, and Sharpless, N.B., 1983, Ground-water supply potential and procedures for well-site selection in the upper Cape Fear River basin. North Carolina: North Carolina Department of Natural Resources and Community Development, $73 \mathrm{p}$.

DeWiest, R.J.M., Sayre, A.N., and Jacob, C.E., 1967, Evaluation of potential impact of phosphate mining on ground-water resources of eastern North Carolina: North Carolina Department of Water Resources. 
Dodson, C.L., and Laney, R.L., 1968, Geology and ground-water resources of the Murphy area, North Carolina: North Carolina Department of Water and Air Resources, Division of Ground Water, Ground-Water Bulletin No. 13, 113 p.

Duncan, D.A., and Peace, R.R., 1966, Ground-water resources of Cleveland County, North Carolina: North Carolina Department of Water Resources, Division of Ground Water, Ground-Water Bulletin No. 11, 65 p.

Eimers, J.L. , Lyke, W.L., and Brockman, A.R., 1990, Simulation of ground-water flow in aquifers in Cretaceous rocks in the central Coastal Plain, North Carolina: U.S. Geological Survey Water-Resources Investigations Report 89-4153, $101 \mathrm{p}$.

Floyd, E.O., 1965, Geology and ground-water resources of the Monroe area, North Carolina: North Carolina Department of Water Resources, Division of Ground Water, Ground-Water Bulletin No. 5, 109 p.

1969. Ground-water resources of Craven County, North Carolina: U.S. Geological Survey Hydrologic Investigations Atlas HA-343.

Floyd, E.O., and Peace, R.R., 1974, An appraisal of the groundwater resources of the upper Cape Fear River basin, North Carolina: North Carolina Department of Water and Air Resources, Groundwater Division, Groundwater Bulletin No. $20,17 p$.

Giese, G.L., Eimers, J.L., and Coble, R.W., 1991, Simulation of ground-water flow in the Coastal Plain aquifer system of North Carolina: U.S. Geological Survey Open-File Report 90-372, $178 \mathrm{p}$.

Giese, G.L., Mason, R.R., and Strickland, A.G., 1987, North Carolina ground-water quality, in National water summary 1986--Hydrologic events and ground-water quality: U.S. Geological Survey Water Supply Paper 2325, p. 393-400.

Groves, M.R., 1976, Preliminary report on groundwater resources of Rowan County, North Carolina: North Carolina Department of Natural and Economic Resources, Division of Environmental Management, Groundwater Section, Bulletin No. 22. $63 \mathrm{p}$.

Harned, D.A., 1989, The hydrogeologic framework and a reconnaissance of groundwater quality in the Piedmont Province of North Carolina, with a design for future study: U.S. Geological Survey Water-Resources Investigations Report $88-4130,55 \mathrm{p}$. 
Harned, D.A., Lloyd, O.B., Jr., and Treece, M.W., Jr., 1989, Assessment of hydrologic and hydrogeologic data at Camp Lejeune Marine Corps Base, North Carolina: U.S. Geological Suney Water-Resources Investigations Report 89-4096, 64 p.

Harris, W.H., and Wilder, H.B., 1964, Ground-water supply of Cape Hatteras National Seashore recreational area, North Carolina-Part 3: North Carolina Department of Water Resources, Division of Ground Water, Report of Investigations No. 4, $22 \mathrm{p}$.

1966, Geology and ground-water resources of the Hertford-Elizabeth City area, North Carolina: North Carolina Department of Water Resources, Division of Ground Water, Ground-Water Bulletin No. 10, 89 p.

Heath, R.C., 1980, Basic ground-water hydrology: U.S. Geological Survey WaterSupply Paper 2220, $84 p$.

1982. Classification of ground-water systems of the United States, in Ground Water, July-August 1982, v. 20, no. 4: Water Well Journal Publishing Company, p. 393-401.

Heath, R.C., and Giese, G.L., 1980, What about ground water in the Pledmont and mountains of North Carolina-Are large supplies feasible?: U.S. Geological Survey (brochure).

Kimrey, J.O., 1960, Ground-water supply of Cape Hatteras National Seashore recreational area, Part 2: North Carolina Department of Water Resources, Division of Ground Water, Report of Investigations No. 2.

1961, Ground-water supply for the Dare Beaches Sanitary District: North Carolina Department of Water Resources, Division of Ground Water, Report of Investigations No. 3.

Laymon, L.L., and Barksdale, R.G., 1964, Ground-water conditions in the Clinton area, North Carolina: North Carolina Department of Water Resources, Division of Ground Water, Ground-Water Circular 3.

LeGrand, H.E., 1954, Geology and ground water in the Statesville area, North Carolina: North Carolina Department of Conservation and Development, Division of Mineral Resources, Bulletin 68, $68 \mathrm{p}$.

1956, Ground-water resources in North Carolina: North Carolina Department of Conservation and Development Bulletin 69. 
1960. Geology and ground-water resources of the Wilmington-New Bern area:

North Carolina Department of Water Resources, Division of Ground Water, Ground-Water Bulletin No. 1,80 p.

1967. Ground water of the Pledmont and Blue Ridge Provinces in the southeastern states: U.S. Geological Suney Circular 538.

LeGrand, H.E., and Mundorff, M.J., 1952, Geology and ground water in the Charlotte area, North Carolina: North Carolina Department of Conservation and Development, Division of Mineral Resources, Bulletin No. 63, 88 p.

Lloyd, O.B., Jr., 1968a, Ground-water resources of Chowan County, North Carolina:

U.S. Geological Survey Hydrologic Investigations Atlas HA-292.

1968b, Ground-water resources of Chowan County, North Carolina: North Carolina Department of Water and Air Resources, Division of Ground Water, Ground-Water Bulletin No. 14, 133 p.

Lloyd, O.B., Jr., and Daniel, C.C., III, 1988, Hydrogeologic setting, water levels, and quality of water from supply wells at the U.S. Marine Corps Air Station, Cherry Point, North Carolina: U.S. Geological Survey Water-Resources Investigations Report 88-4034, $76 \mathrm{p}$.

Lloyd, O.B., Jr., and Davis, R.W., 1989, Preliminary hydrogeologic evaluation of the Cincinnati arch region for underground high-level radioactive waste disposal, Indiana, Kentucky, and Ohio: U.S. Geological Survey WaterResources Investigations Report 88-4098, 42 p.

Lloyd, O.B., Jr., and Dean, R.B., 1968, Ground-water supply of Cape Hatteras National Seashore recreational area, North Carolina, Part 6: North Carolina Department of Water and Air Resources, Division of Ground Water, Report of Investigations No. 7.29 p.

Lloyd, O.B., Jr., and Floyd, E.O., 1968, Ground-water resources of the Belhaven area, North Carolina: North Carolina Department of Water and Air Resources, Division of Ground Water, Report of Investigations No. 8, 38 p.

Lloyd, O.B., Jr., and Reid, M.S., 1986, Evaluation of liquid-waste storage potential based on porosity distribution in the Paleozoic rocks in central and southern parts of the Appalachian basin: U.S. Geological Survey Professional Paper $1468,81 \mathrm{p}$. 
Lloyd, O.B., Jr., and Wilder, H.B., 1968, Ground-water supply of Cape Hatteras National Seashore recreational area. North Carolina, Part 4: North Carolina Department of Water and Air Resources, Division of Ground Water, Report of Investigations No. 5, 19 p.

Lloyd, O.B., Jr., Larson, J.D., and Davis, R.W., 1985, Summary of northern Aflantic Coastal Plain hydrology and its relation to disposal of high-level radioactive waste in buried crystalline rock, a preliminary appraisal: U.S. Geological Suney Water-Resources Investigations Report 85-4146, 80 p.

Lohman, S.W., 1936, Geology and ground-water resources of Elizabeth City area, North Carolina: U.S. Geological Survey Water-Supply Paper 773-A, 57 p.

Lyke, W.L., 1990, Ground-water study of the central Coastal Plain, North Carolina: U.S. Geological Survey Open-File Report 90-192 (Water Fact Sheet).

Lyke, W.L., and Brockman, A.R., 1990, Ground-water pumpage and water-level declines in the Peedee and Black Creek aquifers in Onslow and Jones Counties, North Carolina, 1900-86: U.S. Geological Survey Water-Resources Investigations Report 89-4197, $32 \mathrm{p}$.

Lyke, W.L., and Coble, R.W., 1987, Regional study of the Castle Hayne aquifer of eastern North Carolina: U.S. Geological Survey Open-File Report 87-571, 2 p. (Water Fact Sheet).

Lyke, W.L., and Winner, M.D., Jr., 1986, Altitude of basement surface in the central Coastal Plain area of North Carolina: U.S. Geological Survey Water-Resources Investigations Report 86-4082, 2 sheets.

1990. Hydrogeology of aquifers in Cretaceous and younger rocks in the vicinity of Onslow and southern Jones Counties, North Carolina: U.S. Geological Survey Water-Resources Investigations Report 89-4128, 49 p.

Lyke, W.L., Winner, M.D., Jr., and Brockman, A.R., 1989, Potentiometric surface of the Black Creek aquifer in the central Coastal Plain of North Carolina, December 1986: U.S. Geological Survey Water-Resources Investigations Report 87-4233, 1 sheet.

Marsh, O.T., and Laney, R.L., 1966. Reconnaissance of the ground-water resources in the Waynesville area, North Carolina: North Carolina Department of Water Resources, Division of Ground Water, Ground-Water Bulletin No. 8, 131 p. 
May, V.J., and Thomas, J.D., 1968, Geology and ground-water resources in the Raieigh area, North Carolina: North Carolina Department of Water and Air Resources, Division of Ground Water, Ground-Water Bulletin No. 15, 135 p.

Mundorff, M.J., 1945, Progress report on ground water in North Carolina: North Carolina Department of Conservation and Development, Division of Mineral Resources, Bulletin 47, $78 \mathrm{p}$.

1946. Ground water in the Halifax area, North Carolina: North Carolina Department of Conservation and Development, Division of Mineral Resources, Bulletin 51, $76 \mathrm{p}$.

1948, Ground water in the Greensboro area, North Carolina: North Carolina Department of Conservation and Development, Division of Mineral Resources, Bulletin 55, $108 \mathrm{p}$.

1950, Flood-plain deposits of North Carolina Piedmont and mountain streams as a possible source of ground-water supply: North Carolina Department of Conservation and Development, Division of Mineral Resources, Bulletin 59, $20 \mathrm{p}$.

Murray, L.C., and Keoughan, K.M., 1990, Hydrogeologic data, water levels, and quality of water from monitoring wells installed at the U.S. Marine Corps Air Station, Cherry Point, North Carolina: U.S. Geological Survey WaterResources Investigations Report 89-4200, 86 p.

Nelson, P.F., 1964, Geology and ground-water resources of the Swanquarter area: North Carolina Department of Water Resources, Division of Ground Water, Ground-Water Bulletin No. 4, 79 p.

Nelson, P.F., and Barksdale, R.G., 1965, Interim report on the ground-water resources of the Kinston area, North Carolina: North Carolina Department of Water Resources Ground-Water Circular 10.

Peace, R.R., Jr., and Link, D.R., 1971, Geology and ground-water resources of northwestern North Carolina: North Carolina Department of Water and Air Resources Ground-Water Bulletin 19.

Pusey, R.D., 1960, Geology and ground water in the Goldsboro area, North Carolina: North Carolina Department of Water Resources Ground-Water Bulletin 2, 77 . 
Schipf, R.G., 1961, Geology and ground-water resources of the Fayetteville area: North Carolina Department of Water Resources, Division of Ground Water, Ground-Water Bulletin No. 3,99 p.

Sumsion, C.T., 1968, Summary of the geology and ground-water resources of Pitt County, North Carolina: U.S. Geological Survey Hydrologic Investigations Atlas HA-291.

1970, Geology and ground-water resources of Pitt County, North Carolina: North Carolina Department of Water and Air Resources, Division of Ground Water, Ground-Water Bulletin No. 18, 75 p.

Sumsion, C. T., and Laney, R. L., 1967, Geology and ground-water resources of the Morganton area, North Carolina Department of Water Resources, Division of Ground Water, Ground-Water Bulletin No. 12, 119 p.

Trapp, Henny, Jr., 1970, Geology and ground-water resources of the Asheville area, North Carolina: North Carolina Department of Water and Air Resources Ground-Water Bulletin 16.

Winner, M.D., Jr., 1975, Ground-water resources of the Cape Hatteras National Seashore, North Carolina: U.S. Geological Survey Hydrologic Investigations Atlas HA-540.

1976, Ground-water resources of Wilson County, North Carolina: U.S. Geological Survey Water-Resources Investigations 76-60, 85 p.

1977, Ground-water resources along the Blue Ridge Parkway, North Carolina:

U.S. Geological Survey Water-Resources Investigations 77-65, 170 p.

1978, Ground-water resources of the Cape Lookout Nationai Seashore, North Carolina: U.S. Geological Survey Water-Resources Investigations 78-52, 49 p.

1981a, An observation-well network concept as applied to North Carolina:

U.S. Geological Survey Water-Resources Investigations 81-13, 59 p.

1981b. Proposed observation-well networks and ground-water level program for North Carolina: U.S. Geological Survey Open-File Report 81-544, 68 p.

Winner, M.D., Jr., and Coble, R.W., 1989, Hydrogeologic framework of the North Carolina Coastal Plain aquifer system: U.S. Geological Survey Open-File Report 87-690 (pending publication as Professional Paper 1404-I), 155 p. 
Winner, M.D., Jr., and Lyke, W.L., 1986, History of ground-water pumpage and waterlevel decline in the Biack Creek and upper Cape Fear aquifers of the centrai Coastal Plain of North Carolina: U.S. Geological Survey Water-Resources Investigations Report 86-4168, 21 p.

1989. Aquifers of Cretaceous rocks of the centrai Coastai Piain of North Carolina: U.S. Geological Survey Water-Resources Investigations Report 87-4178, $71 \mathrm{p}$.

Winner, M.D., Jr., Lyke, W.L., and Brockman, A.R., 1989a, Potentiometric surface of the lower Cape Fear aquifer in the central Coastal Plain of North Carolina, December 1986: U.S. Geological Survey Water-Resources Investigations Report 87-4234, 1 sheet.

1989b, Potentiometric surface of the upper Cape Fear aquifer in the centrai Coastai Piain of North Carolina, December 1986: U.S. Geological Survey Water-Resources Investigations Report 87-4235, 1 sheet.

Wyrick, G.G., 1966, Ground-water resources of Martin County, North Carolina: North Carolina Department of Water Resources, Division of Ground Water, GroundWater Bulletin No. 9,85 p.

1967. Water-bearing characteristics and occurrence of aquifers in Martin County, North Carolina: U.S. Geological Survey Hydrologic Investigations Atlas HA-264.

Wyrick, G.G., and Dean, R.B., 1968, Ground-water supply of Cape Hatteras National Seashore recreational area, North Carolina, Part 5: North Carolina Department of Water and Air Resources, Division of Ground Water, Report of Investigations No. 6.29p.

\section{Water Use}

Jackson, N.M., Jr., 1972, Public water supplies of North Carolina--Part 1, Northern

Piedmont: North Carolina Department of Natural and Economic Resources, $277 \mathrm{p}$ 1973. Public water supplies of North Carolina--Part 2, Southern Piedmont: North Carolina Department of Natural and Economic Resources, 255 p.

1974, Public water supplies of North Carolina--Part 3, Mountains and Western

Piedmont: North Carolina Department of Natural and Economic Resources, $232 \mathrm{p}$ 
Mann, L.T., Jr., 1978, Public water supplies of North Carolina, A summary of water sources, use, treatment, and capacity of water-supply systems: U.S. Geological Survey Water-Resources Investigations 78-16.

Robison, T.M., 1977, Public water supplies of North Carolina--Part 4, Northern Coastal Plain: North Carolina Department of Natural and Economic Resources, $218 \mathrm{p}$.

Robison, T.M., and Mann, L.T., Jr., 1977, Public water supplies of North Carolina-Part 5, Southern Coastal Plain: North Carolina Department of Natural and Economic Resources, $333 \mathrm{p}$.

Solley, W.B., Merk, C.F., and Pierce, R.R., 1988, Estimated use of water in the United States in 1985: U.S. Geological Survey Circular 1004, 82 p.

Treece, M.W. , Jr., 1990, Water withdrawals in the Roanoke-Chowan subregion of North Carolina and Virginia, 1983: U.S. Geological Survey Water-Resources Investigations Report 90-4007, 1 sheet. 